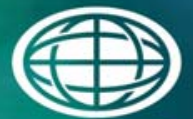

Savannah River

National Laboratory ${ }^{m}$

OPERATED BY SAVANNAH RIVER NUCLEAR SOLUTIONS

\title{
Sludge Batch 9 Follow-on Actual-Waste Testing for the Nitric-Glycolic Flowsheet
}

C.J. Martino

J.D. Newell

C.L. Crawford

J.M. Pareizs

M.S. Williams

March 2017

SRNL-STT-2016-00726, Revision 0 
SRNL-STI-2016-00726

Revision 0

\section{DISCLAIMER}

This work was prepared under an agreement with and funded by the U.S. Government. Neither the U.S. Government or its employees, nor any of its contractors, subcontractors or their employees, makes any express or implied:

1. warranty or assumes any legal liability for the accuracy, completeness, or for the use or results of such use of any information, product, or process disclosed; or

2. representation that such use or results of such use would not infringe privately owned rights; or

3. endorsement or recommendation of any specifically identified commercial product, process, or service.

Any views and opinions of authors expressed in this work do not necessarily state or reflect those of the United States Government, or its contractors, or subcontractors.

\section{Printed in the United States of America \\ Prepared for U.S. Department of Energy}


Keywords: DWPF, Sludge Batch 9, Tank Farm

Retention: Permanent

\title{
Sludge Batch 9 Follow-on Actual-Waste Testing for the Nitric-Glycolic Flowsheet
}

\author{
C.J. Martino \\ J.D. Newell \\ C.L. Crawford \\ J.M. Pareizs \\ M.S. Williams
}

March 2017

Prepared for the U.S. Department of Energy under contract number DE-AC09-08SR22470. 


\section{REVIEWS AND APPROVALS}

\section{AUTHORS:}

C.J. Martino, Process Technology Programs Date

J.D. Newell, Process Technology Programs Date

C.L. Crawford, Engrg. Process Development Date

J.M. Pareizs, Process Technology Programs Date

M.S. Williams, Process Technology Programs

Date

\section{TECHNICAL REVIEW:}

W.H. Woodham, Process Technology Programs, Reviewed per E7 2.60

Date

F.C. Johnson, Engrg. Process Development, Reviewed per E7 2.60

Date APPROVAL:

F.M. Pennebaker, Manager Date Process Technology Programs

D.E. Dooley, Director Date Environmental \& Chemical Process Technology Research Programs 
SRNL-STI-2016-00726

Revision 0

\section{EXECUTIVE SUMMARY}

An actual-waste Sludge Batch 9 qualification run with the nitric-glycolic flowsheet (SC-18) was performed in FY16. In order to supplement the knowledge base for the nitric-glycolic flowsheet, additional testing was performed on the product slurries, condensates, and intermediate samples from run SC-18. The following is a summary of the scope of the follow-on testing:

- Feed and product slurries were analyzed for volatile and semivolatile organic components.

- SRAT product material was adjusted to $\mathrm{pH}$ of 3,2, and 1 with mixtures of glycolic and nitric acid, and the solubilities of metals important to nuclear criticality safety were measured.

- Closed crucible -hot insertion glass melts were performed on the SME product and iron REDOX was evaluated.

- A Product Consistency Test (PCT) on glass made from the SME product.

- SRAT and SME condensate samples were analyzed for total mercury and antifoam degradation products.

- Intermediate slurry and filtrate samples were analyzed for mercury, other metals, and anions.

The following are the results of the follow-on testing:

- In completion of the additional tasks pertaining to the Sludge Batch 9 actual waste qualification for the nitric-glycolic flowsheet, the results obtained did not conflict with the prior conclusions. Based on the current and previous studies, SRNL recommends implementation of the nitricglycolic acid flowsheet in DWPF

- All results for the volatile organics analysis and semi-volatile organics analysis of the Sludge Receipt and Adjustment Tank (SRAT) receipt, SRAT product, and Slurry Mix Evaporator (SME) product slurries were below the method detection limits $(<6$ to $<16 \mathrm{mg} / \mathrm{L})$.

- In the condensate, the highest soluble mercury concentrations are observed in the early stages of the SRAT cycle (405 $\mathrm{mg} / \mathrm{L}$ at initial heat to boiling).

- Trimethylsilanol, an antifoam degradation product, was measured in the condensate samples at the end of the SRAT cycle and throughout the SME cycle, ranging from 11 to $62 \mathrm{mg} / \mathrm{L}$ when above the $0.25 \mathrm{mg} / \mathrm{L}$ detection limit. Propanal was quantified just above the $0.25 \mathrm{mg} / \mathrm{L}$ detection limit $(0.27$ and $0.34 \mathrm{mg} / \mathrm{L})$ for two of the nine dewater samples collected during the SME cycle. Hexamethyldisiloxane was not measured above the $0.25 \mathrm{mg} / \mathrm{L}$ detection limit.

- From the measurement of mercury from the intermediate and final slurry samples taken during the SC-18 SRAT cycle, mercury stripping appeared to require approximately 1000 grams of conflux (or steam) per gram of mercury stripped. 
- Intermediate SRAT slurry samples taken throughout the run showed a gradual removal of nitrite to approximately $2000 \mathrm{mg} / \mathrm{kg}$ in the slurry sample after 13 hours of conflux and $300 \mathrm{mg} / \mathrm{kg}$ in the SRAT product sample after 24 hours of conflux.

- After adjusting the SC-18 SRAT product to $\mathrm{pH}$ values of 3,2, and 1 with glycolic and nitric acid, the minimum $\mathrm{Fe}: \mathrm{Pu}-239$ ratio in the slurry was 1,700 for the aqua regia digested slurries and 1,510 for the peroxide fusion digested slurries. The minimum $\mathrm{Mn}: \mathrm{Pu}-239$ ratio in the slurry was 748 for the aqua regia digested slurries and 480 for the peroxide fusion digested slurry. The maximum concentration of soluble $\mathrm{Pu}-239$ was $3.77 \mathrm{mg} / \mathrm{kg}$ (at $\mathrm{pH}=1$ ).

- Based on the measured composition of the SC-18 qualification glass, the product consistency test responses of $\mathrm{B}, \mathrm{Li}$, and $\mathrm{Na}$ are acceptable relative to the chemical durability of the Environmental Assessment benchmark glass and predictable by current Product Composition Control System models for durability.

- Two out of the three crucible samples prepared from SC-18 SME product were deemed acceptable with an accepted measured reduction/oxidation (REDOX: $\mathrm{Fe}^{2+} / \Sigma \mathrm{Fe}$ ) ratio mean of 0.05 with a standard error of 0.01 . 


\section{TABLE OF CONTENTS}

LIST OF TABLES viii

LIST OF FIGURES ix

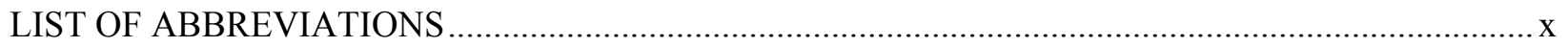

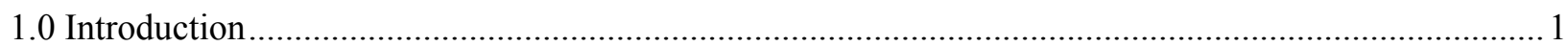

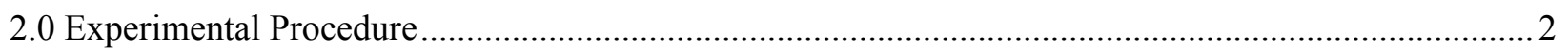

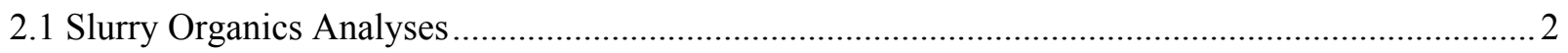

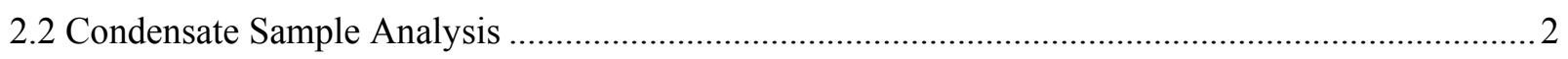

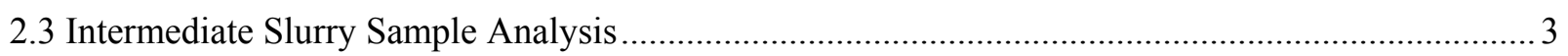

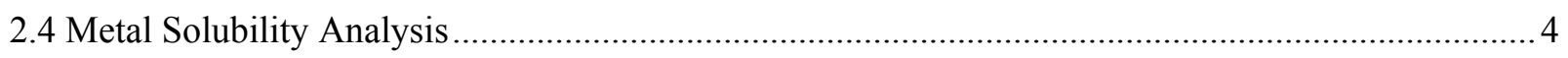

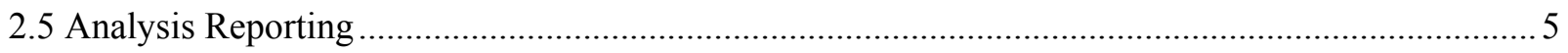

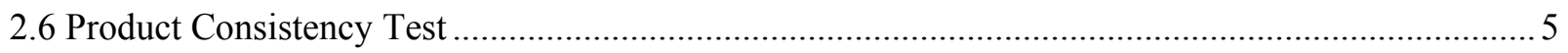

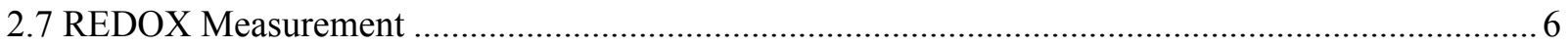

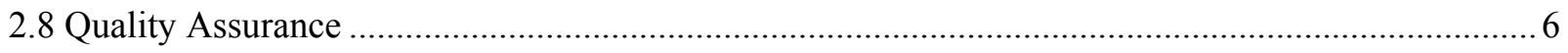

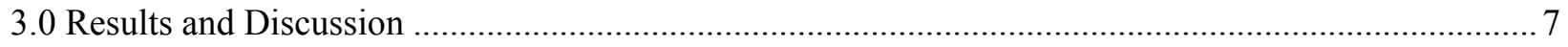

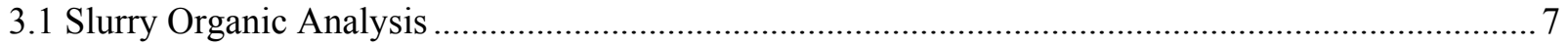

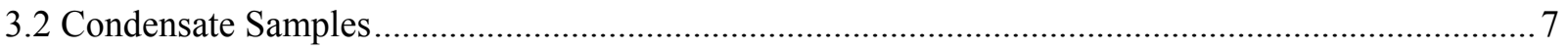

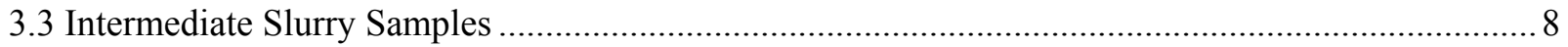

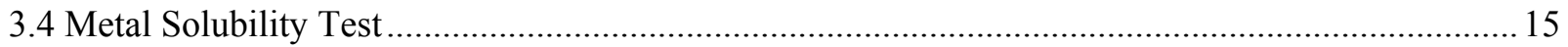

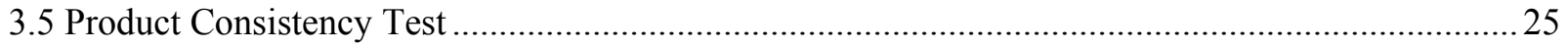

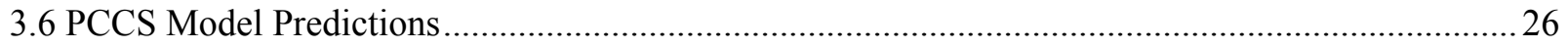

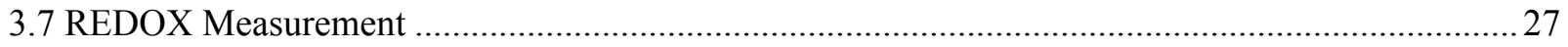

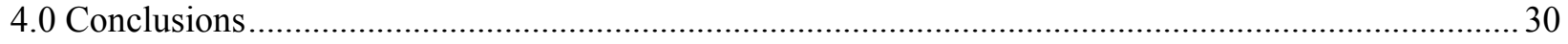

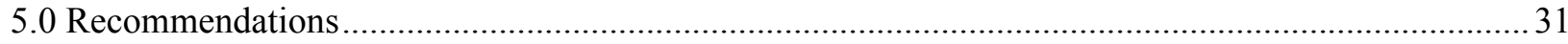

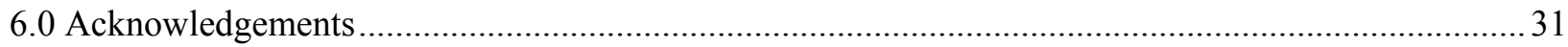

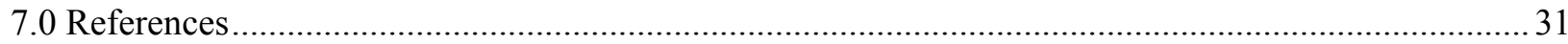

Appendix A . Replicate Analyses from Metal Solubility Tests ............................................................A-1 


\section{LIST OF TABLES}

Table 2-1. Analyses Performed on Condensate Samples Taken During SC-18 SRAT/SME Test............. 3

Table 2-2. Number and Timing of Intermediate Samples Taken During SC-18 SRAT Test .................... 4

Table 3-1. Results from Slurry Organics Analyses............................................................................ 7

Table 3-2. Condensate Sample Results for Mercury and ADPs ......................................................... 8

Table 3-3. Slurry Mercury Concentration during SRAT Processing ..................................................... 9

Table 3-4. Anion Concentration During SRAT Processing (mg/kg of Slurry)....................................... 11

Table 3-5. Metal and Isotope Concentration in Filtrate ( $\mathrm{mg} / \mathrm{kg}$ of Supernatant) .................................... 13

Table 3-6. Anion, TIC, and TOC Concentration in Filtrate (mg/kg of Supernatant).............................. 14

Table 3-7. Solids Contents of pH Adjusted SRAT Product................................................................. 15

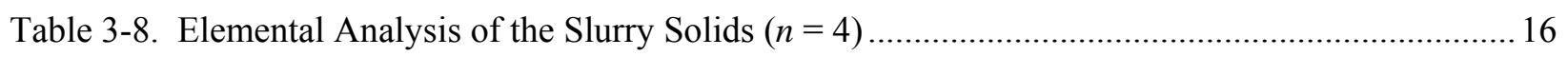

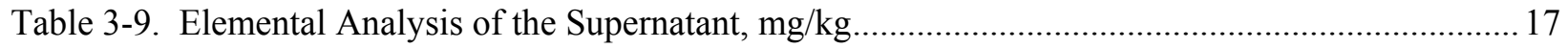

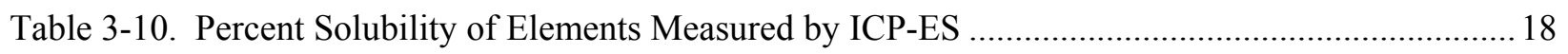

Table 3-11. Percent Solubility of Select Radionuclides as Measured by ICP-MS .................................. 18

Table 3-12. Comparison of pH Adjusted Slurry Analysis Results ....................................................... 19

Table 3-13. Comparison of pH Adjusted Slurry Filtrate Analysis Results ............................................20

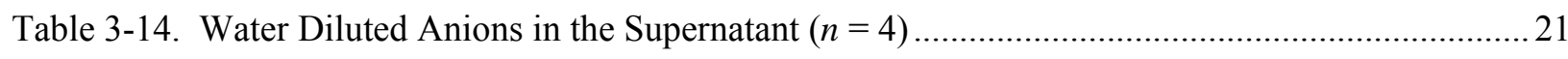

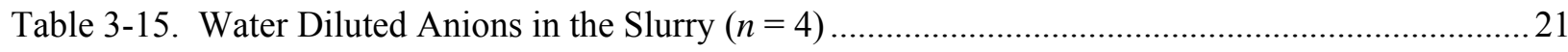

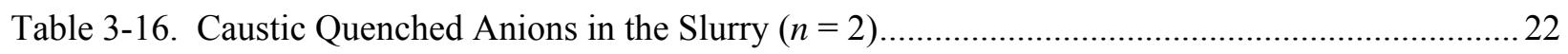

Table 3-17. Concentrations and Ratios of Select Components of the AR Digested Slurries.................... 23

Table 3-18. Concentrations and Ratios of Select Components of the PF Digested Slurries.....................2 23

Table 3-19. Iron to Pu-239 Ratios and Concentrations on an Insoluble Solids Basis...............................24

Table 3-20. Concentrations and Ratios of Select Components from Previous Glycolic-Formic

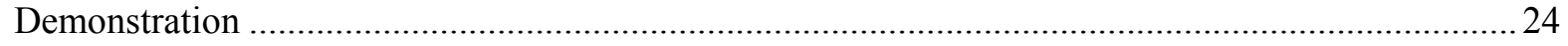

Table 3-21. Multi-Element Standard Solution Results (SM-744-013) ..................................................25

Table 3-22. $\mathrm{NC}_{i}$ Results Using the Average of the Common Logarithms of the Leachate Concentrations for ARM, EA and the SB9 SC-18 Qualification Glass....................................................................26

Table 3-23. REDOX $\left(\mathrm{Fe}^{2+} / \Sigma \mathrm{Fe}\right)$ Measurements in the Cells. ...................................................................29

Table 3-24. Comparison of Predicted and Measured REDOX Values ...................................................29 


\section{LIST OF FIGURES}

Figure 3-1. Mercury Concentration in Slurry Samples, Indicating Mercury Stripping during the SC-18 SRAT Cycle

Figure 3-2. Estimated Mercury Remaining in Slurry During SC-18 SRAT Cycle.................................. 10

Figure 3-3. Nitrite Decomposition During the SC-18 SRAT Cycle .................................................... 11

Figure 3-4. Anion Concentration in Slurry Samples from the SC-18 SRAT Cycle ............................... 12

Figure 3-5. Soluble Concentration of Select Metals Throughout the SC-18 SRAT Cycle........................ 14

Figure 3-6. $\Delta \mathrm{G}_{\mathrm{p}}$ predictions (kcal/100 g glass) versus the log of the normalized concentration $(\mathrm{g} / \mathrm{L})$ for $\mathrm{B}$, $\mathrm{Li}, \mathrm{Na}$, and $\mathrm{Si} ; \mathrm{X}$ represent published EA values, ${ }^{8} \bullet$ represent ARM values and $\bullet$ represent measured SB9 SC-18 Qualification Glass values............................................... Error! Bookmark not defined.

Figure 3-7. A) Image of cooled crucible (note: cracks in the alumina formed upon cooling, not during vitrification); B) Image of extracted glass sample ........................................................................ 28

Figure 3-8. Plot of Normal Distribution (red) and Logarithmic-corrected Distribution (green) for the REDOX Replicates. 30 


\section{LIST OF ABBREVIATIONS}

\begin{tabular}{|c|c|}
\hline $\mathrm{AD}$ & Analytical Development \\
\hline ADPs & Antifoam Degradation Products \\
\hline AR & Aqua Regia \\
\hline ARM & Approved Reference Material \\
\hline ASTM & American Society for Testing and Materials \\
\hline $\mathrm{CC}_{\mathrm{Hot}}$ & Closed Crucible Hot Insertion \\
\hline CPC & Chemical Processing Cell \\
\hline CQ & Caustic Quench \\
\hline CVAA & Cold-Vapor Atomic Absorption \\
\hline DWPF & Defense Waste Processing Facility \\
\hline EA & Environmental Assessment \\
\hline HMDSO & Hexamethyldisiloxane \\
\hline $\mathrm{IC}$ & Ion Chromatography \\
\hline ICA & Ion Chromatography for Anions \\
\hline $\mathrm{ICC}$ & Ion Chromatography for Cations \\
\hline ICP-AES & Inductively Coupled Plasma - Atomic Emission Spectroscopy \\
\hline ICP-MS & Inductively Coupled Plasma - Mass Spectroscopy \\
\hline KMA & Koopman Minimum Acid \\
\hline MAR & Measurement Acceptability Region \\
\hline MWWT & Mercury Water Wash Tank \\
\hline NA & Not Applicable \\
\hline $\mathrm{NC}$ & Normalized Concentration \\
\hline PCCS & Product Composition Control System \\
\hline PCT & Product Consistency Test \\
\hline $\mathrm{PF}$ & Peroxide Fusion \\
\hline PSAL & Process Science Analytical Laboratory \\
\hline REDOX & REDuction/OXidation \\
\hline RSD & Relative Standard Deviation \\
\hline SB & Sludge Batch \\
\hline $\mathrm{SC}$ & Shielded Cells \\
\hline SME & Slurry Mix Evaporator \\
\hline SRAT & Sludge Receipt and Adjustment Tank \\
\hline SRNL & Savannah River National Laboratory \\
\hline SRR & Savannah River Remediation \\
\hline SVOA & Semivolatile Organics Analysis \\
\hline TBP & Tributylphosphate \\
\hline THERMO & Thermodynamic Hydration Energy Model \\
\hline TMS & Trimethylsilanol \\
\hline VOA & Volatile Organics Analysis \\
\hline WAPS & Waste Acceptance Product Specifications \\
\hline
\end{tabular}




\subsection{Introduction}

Savannah River National Laboratory (SRNL) is evaluating the use of glycolic acid to replace the formic acid currently used in the Defense Waste Processing Facility (DWPF) to reduce facility hazards and improve processing times. Testing has shown glycolic acid to be effective in replacing the function of formic acid in the DWPF chemical process. The nitric-glycolic flowsheet chemically reduces mercury, significantly lowers the catalytic generation of hydrogen and ammonia (which could allow purge reduction in the Sludge Receipt and Adjustment Tank (SRAT)), stabilizes the $\mathrm{pH}$ and chemistry in the SRAT and the Slurry Mix Evaporator (SME), and allows for effective rheology adjustment. ${ }^{1}$

In order to implement the new flowsheet, SRAT and SME cycles, designated SC-18, were performed using a Sludge Batch (SB) 9 slurry blended from SB8 Tank 40 and SB9 Tank 51 samples. Chemical Process Cell (CPC) demonstrations utilizing the nitric-glycolic flowsheet were performed at an acid stoichiometry of 78.0\% Koopman Minimum Acid (KMA) basis (87.1\% Hsu basis) for the SRAT cycle. The results of the qualification run with the nitric-glycolic flowsheet are included in a separate technical report. $^{2}$ This report addresses additional results and intermediate condensate and slurry sample analysis from the CPC demonstration of the nitric-glycolic flowsheet as requested in the Savannah River Remediation (SRR) Technical Task Request (TTR) ${ }^{3}$ and described in the Task Technical and Quality Assurance Plan (TTQAP). ${ }^{4}$ This report satisfies Deliverable 2 of the TTR.

The following list rephrases the seven tasks that were requested in the TTR:

1. Perform Volatile Organics Analysis (VOA) and Semivolatile Organics Analysis (SVOA) on the SRAT receipt, SRAT product, and SME product.

2. Determine the metal solubilities in the Nitric-Glycolic flowsheet SRAT product at reduced $\mathrm{pH}$ of 3,2 , and 1 .

3. Perform "Closed Crucible - hot insertion" $\left(\mathrm{CC}_{\mathrm{Hot}}\right)$ glass melts of the SME product and measure REDOX, evaluate REDOX measurement versus the prediction.

4. Perform a Product Consistency Test (PCT) on glass made from the SME product.

5. Measure the radiolytic hydrogen release (after periods of quiescent time) in the lab-scale vessel prior to and at the onset of mixing.

6. Analyze for total mercury in the SRAT and SME condensate samples.

7. Analyze for the antifoam degradation products (ADPs) in the condensate samples.

The results of the measurement of radiolytic hydrogen release for the SRAT receipt and SRAT product prior to and at the onset of mixing (TTR Task 5) was included in the previous report. ${ }^{2}$ It was not possible to obtain radiolytic hydrogen release data for SME product because of conflicts with higher priority tasks such as rheology measurement. Likewise, VOA results for SRAT receipt and SME product were also reported previously. ${ }^{2}$

In addition to the seven items listed above, intermediate slurry and filtrate samples were analyzed from the SC-18 SRAT cycle. Analyses included mercury, metals, and anions.

This report completes the planned work with actual-waste nitric-glycolic flowsheet SB9 qualification run SC-18. 
SRNL-STI-2016-00726

Revision 0

\subsection{Experimental Procedure}

\subsection{Slurry Organics Analyses}

Slurry samples were diluted with water by a factor of approximately 45 -times and were submitted for VOA. VOA is designed to quantify organic materials boiling below $150{ }^{\circ} \mathrm{C}$, including the specific analytes benzene, toluene, isopropanol, and butanol. VOA would be able to quantify trimethylsilanol (TMS) and propanal to approximately $10 \mathrm{mg} / \mathrm{L}$ after dilution factors are applied.

Slurry samples were extracted with methylene chloride to measure semivolatile organic compounds via SRNL-Analytical Development (AD) SVOA method. Compounds quantified by this method generally include those organic materials boiling above $150{ }^{\circ} \mathrm{C}$. Diluted slurry aliquots were mixed with a concentrated sodium nitrate solution and extracted. The extractant from this process yields the process chemicals tributylphosphate (TBP), Isopar, and Norpar. A second set of diluted slurry aliquots was mixed with a buffer at $\mathrm{pH}$ 7. The extractant from this process yields n-paraffin, and phenol. Slurry was diluted by approximately 35-times to reduce insoluble solids concentration; insoluble solids make it difficult to distinguish the aqueous and organic layers in the cells. $5 \mathrm{~mL}$ of diluted slurry was mixed with $5 \mathrm{~mL}$ of buffer and extracted with $10 \mathrm{~mL}$ of methylene chloride. SVOA would be able to quantify TMS and hexamethyldisiloxane (HMDSO) to approximately $10 \mathrm{mg} / \mathrm{L}$ after dilution factors are applied.

\subsection{Condensate Sample Analysis}

Table 2-1 contains a list of condensate samples taken during the SRAT and SME cycles of the SC-18 test and the analyses that were performed on the samples. The first four samples listed were pulled from the Mercury Water Wash Tank (MWWT) during portions of the SRAT cycle. The dewater samples were taken from the stored bottles of dewater for different stages of the SRAT and SME cycle. The SRAT and SME ice cube samples were taken from the material condensed in the cold finger on the offgas line after the primary condenser. The SRAT Dewater Composite sample represents the average condensate during the time period between the Heat to Boiling and End of Dewater MWWT samples. MWWT samples represent shorter periods of processing than the SRAT Dewater Composite, SME dewater samples, and ice cube samples. Additional details of the test apparatus configuration are contained in a separate report. ${ }^{2}$

Ion chromatography for anions (ICA) and ion chromatography for cations (ICC) were reported for condensate samples previously. ${ }^{2}$ In this report, condensate samples were digested by potassium permanganate and sulfuric acid and analyzed by cold vapor atomic absorption (CVAA) spectroscopy for mercury. VOA and SVOA were performed on the condensate samples primarily to quantify the ADPs HMDSO, TMS, and propanal. Due to limited volumes of samples collected from the MWWT and ice cube, not all condensate analyses could be performed on all samples, and priority was given to the analyses that were expected to lead to the most useful information for each sample. No analyses were performed on the small amount of condensate collected from the MWWT as the Post Nitric Acid Addition sample. 
Table 2-1. Analyses Performed on Condensate Samples Taken During SC-18 SRAT/SME Test

\begin{tabular}{|l|c|c|c|c|c||}
\hline \hline Process Step & ICA & ICC & Hg & VOA & SVOA \\
\hline Post Nitric Acid Addition & X & X & X & X & X \\
\hline Heat to Boiling & O & O & $\checkmark$ & $\checkmark$ & X \\
\hline End of Dewater & O & O & $\checkmark$ & $\checkmark$ & X \\
\hline 30 min Prior to End of Reflux & O & O & $\checkmark$ & $\checkmark$ & X \\
\hline SRAT Dewater Composite & O & O & $\checkmark$ & $\checkmark$ & $\checkmark$ \\
\hline SRAT Ice Cube & O & O & X & $\checkmark$ & $\checkmark$ \\
\hline Canister Decon. Dewater 1 & O & O & $\checkmark$ & $\checkmark$ & $\checkmark$ \\
\hline Canister Decon. Dewater 2 & O & O & $\checkmark$ & $\checkmark$ & $\checkmark$ \\
\hline Canister Decon. Dewater 3 & O & O & $\checkmark$ & $\checkmark$ & $\checkmark$ \\
\hline Canister Decon. Dewater 4 & O & O & $\checkmark$ & $\checkmark$ & $\checkmark$ \\
\hline Canister Decon. Dewater 5 & O & O & $\checkmark$ & $\checkmark$ & $\checkmark$ \\
\hline Canister Decon. Dewater 6 & O & O & $\checkmark$ & $\checkmark$ & $\checkmark$ \\
\hline Frit Dewater 1 & O & O & $\checkmark$ & $\checkmark$ & $\checkmark$ \\
\hline Frit Dewater 2 & O & O & $\checkmark$ & $\checkmark$ & $\checkmark$ \\
\hline Final Dewater & O & O & $\checkmark$ & $\checkmark$ & $\checkmark$ \\
\hline SME Ice Cube & O & O & X & $\checkmark$ & X \\
\hline O I p & O & $\checkmark$ & $\checkmark$ \\
\hline
\end{tabular}

$\mathrm{O}=$ reported in SRNL-STI-2016-00327, $\checkmark=$ reported in this work, $\mathrm{X}=$ not analyzed

\subsection{Intermediate Slurry Sample Analysis}

Slurry samples were collected at strategic intervals throughout the SRAT cycle to investigate the process chemistry in accordance with Table 2-2. Intermediate slurry samples were based on the sampling recommendations contained in the recommendations memo for this specific run. ${ }^{5}$ The number of samples taken for each type of analysis at each stage of the process is listed in Table 2-2. As indicated in the table, three types of slurry samples were taken: nominally $10 \mathrm{~g}$ slurry samples that were subsequently filtered, nominally $10 \mathrm{~g}$ samples that were subsequently caustic quenched (CQ), and nominally $1 \mathrm{~g}$ samples that were subsequently digested for mercury analysis. The slurry samples were collected through a $3 / 8$ inch (outer diameter) glass sample tube connected to a sample bottle via polyethylene tubing. A stopper was fitted to the sample bottle through which a vacuum was created using a Masterflex pump. The vacuum inside the sample bottle pulled the sample through the sample tube until a stopcock on the glass sample tube was closed. Prior to sampling, the glass sample tube was flushed with air, and new polyethylene tubing was used for each sample. Slurry samples were collected for filtrate/supernatant analysis of soluble components, CQ preparation for analysis of anions, and aqua regia (AR) dissolution for analysis of mercury. 
Table 2-2. Number and Timing of Intermediate Samples Taken During SC-18 SRAT Test

\begin{tabular}{|l|c|c|c|c||}
\hline \multirow{2}{*}{ Process Step } & \multirow{2}{*}{$\begin{array}{c}\text { Conflux } \\
\text { Time (hr) }\end{array}$} & \multicolumn{3}{|c||}{ Number of Samples } \\
\cline { 3 - 5 } & & Filtrate & Slurry CQ & Hg \\
\hline Mid Glycolic Acid Addition & 0 & 1 & 1 & - \\
\hline Post Glycolic Acid Addition & 0 & 1 & 1 & 2 \\
\hline 1.5 hrs into Dewater & 1.5 & 1 & 1 & - \\
\hline 3.0 hrs into Dewater & 3.0 & 1 & 1 & - \\
\hline End of Dewater (Start of Reflux) & 3.25 & - & - & 2 \\
\hline 5.0 hrs into Reflux & 8.25 & 1 & 1 & - \\
\hline 8.0 hrs into Reflux & 11.25 & - & - & 2 \\
\hline 10.0 hrs into Reflux & 13.25 & 1 & 1 & - \\
\hline End of SRAT & 23.5 & - & - & 3 \\
\hline
\end{tabular}

For filtrate analysis, samples of approximately 10 to $15 \mathrm{~g}$ were filtered with a 0.45 micron nylon syringe filter immediately after sampling. Portions of the material were subsequently diluted with either $1 \mathrm{M}$ nitric acid or deionized water. Duplicate acid dilutions were analyzed by inductively coupled plasma atomic emission spectroscopy (ICP-AES) and inductively coupled plasma mass spectrometry (ICP-MS). The ICP-AES measurements provided quantification of most of the elemental constituents reported in this document. ICP-MS provided analysis of some of the metals which were not quantifiable by ICP-AES (Ru, $\mathrm{Rh}, \mathrm{Pu}-239$, etc.). The ICP-AES axial sulfur method was performed for quantifying sulfur.

Slurry samples of approximately 10 to $15 \mathrm{~g}$ were combined with $2 \mathrm{~g}$ of $50 \mathrm{wt} \%$ sodium hydroxide shortly after they were taken. This CQ procedure effectively stops the SRAT chemistry reactions so intermediate levels of components can be determined. CQ material was subsequently diluted by $100 \mathrm{X}$ and analyzed by ICA.

Individual $1-3 \mathrm{~g}$ samples were digested in their entirety by AR and submitted for mercury analysis. To quantify mercury, CVAA spectroscopy was performed without additional potassium permanganate digestion.

\subsection{Metal Solubility Analysis}

SRAT product created during the qualification of SB9 (SC-18) was divided into three $50 \mathrm{~g}$ samples. While mixing the sample and monitoring $\mathrm{pH}, 70 \mathrm{wt} \%$ glycolic acid was added until the $\mathrm{pH}$ no longer decreased. As glycolic acid is known to buffer at $\mathrm{pH} \sim 3$, the addition of $50 \mathrm{wt} \%$ nitric acid was required to achieve lower $\mathrm{pH}$ levels. Each sample was adjusted to one of three $\mathrm{pH}$ targets: $\mathrm{pH} \mathrm{3,} \mathrm{pH} 2$, or $\mathrm{pH} 1$. Once the $\mathrm{pH}$ target was achieved as measured with a Measurement Systems and Equipment (MS\&E) instrument, the sample was allowed to sit for one hour and then prepared for dilution and digestion. Portions of filtrate were prepared using 0.45 micron nylon syringe filters. 
Filtrate samples diluted with nitric acid were submitted for ICP-AES, ICP-MS, PuTTA (plutonium by separation and counting), and $\mathrm{Am} / \mathrm{Cm}$ (americium and curium by separation and counting). Filtrate samples diluted with water were submitted for ICA (including glycolate). Water diluted filtrate also received potassium permanganate and sulfuric acid digestion followed by CVAA spectroscopy for mercury. Filtrate sample preparations were performed in quadruplicate.

Slurry samples were prepared for analysis by quadruplicate AR and peroxide fusion (PF) digestions. AR digestions were analyzed by ICP-AES, ICP-MS, and CVAA. PF digested slurry samples were submitted for ICP-AES and radiochemical analysis (PuTTA and Am/Cm methods). Slurry samples were also prepared by CQ in duplicate and analyzed by ICA.

\subsection{Analysis Reporting}

Results are preceded by "<" when the analyte is below the limits of quantification. Mean results, based on the average of all applicable analytical determinations are reported in this document. In some cases, percent relative standard deviation (\%RSD) and the number of determinations $(n)$ feeding each mean are also reported. \%RSD provides an indication of the measurement variation between replicate determinations, but is typically not an indicator of analytical accuracy. The \%RSD is not applicable (NA) to results that are below the limits of quantification.

In general, the one sigma analytical uncertainty reported by $\mathrm{AD}$ was $10 \%$, although it was sometimes lower or higher. Specifically, the one sigma analytical uncertainties reported by AD were $10 \%$ for IC, ICP-AES, ICP-MS and 20\% for CVAA, SVOA and VOA analysis. For radiochemistry counting analyses, the one sigma analytical uncertainties are included in Appendix A for each replicate.

\subsection{Product Consistency Test}

In order to meet the acceptance criterion stated in Section 1.3 of the Waste Acceptance Product Specifications (WAPS $)^{6}$, the durability of the SB9 SC-18 Qualification Glass was determined by the PCT per Test Method A of American Society for Testing and Materials (ASTM) C1285-14. ${ }^{7}$ The test was performed on four replicates of the SB9 SC-18 Qualification Glass. Duplicate blanks and triplicate samples of the Approved Reference Material (ARM) ${ }^{8}$ and the Environmental Assessment (EA) ${ }^{9}$ glass were also included. Samples were ground, washed, and prepared according to the standard procedure. ${ }^{7}$ Fifteen milliliters of ASTM-type water were added to 1.5 grams of glass per stainless steel vessel. The vessels were closed, tightly sealed, and placed in an oven for 7 days at $90 \pm 2{ }^{\circ} \mathrm{C}$. After 7 days, the stainless steel vessels were removed from the oven, allowed to cool, weighed to determine water loss, and then opened. Due to the radioactivity of the glass, the initial portion of the test was performed remotely in a Shielded Cell. The leachate from each vessel was then decanted into a clean $30 \mathrm{~mL}$ poly bottle. The radioactivity levels of the leachates were low enough that they could be transported to a radiochemical hood where they could be handled directly. The $\mathrm{pH}$ of each leachate was measured, and then the leachates were filtered through a 0.45 micron nylon syringe filter and acidified to 1 volume percent $\mathrm{HNO}_{3}$. The leachates were then diluted and analyzed by ICP-AES. A multi-element ICP standard custom solution from High Purity Standards (Product number SM-744-013) containing known concentrations of Al, B, Fe, $\mathrm{K}, \mathrm{Li}, \mathrm{Na}$, and $\mathrm{Si}$ was also submitted with the samples. 


\subsection{REDOX Measurement}

Three closed crucible melts of actual-waste glass were prepared from SC-18 SME product in order to determine glass REDOX. The method used was based on the $\mathrm{CC}_{\mathrm{Hot}}$ method used for non-radioactive simulant tests, but adjusted to be applicable to performing in the Cell 1 furnace. Non-radioactive simulated SME product (SB9-NG-55, centroid of the test matrix) prepared under the same conditions was utilized as a procedural standard as well as non-radioactive simulated SME product (SB9-NG-57, highly reduced) vitrified outside but analyzed within the Cells. ${ }^{10}$

The procedure for $\mathrm{CC}_{\mathrm{Hot}}$ calls for vitrification of sufficient SME product (or SRAT product plus frit) to fill the chosen crucible (typically a $100 \mathrm{~mL}$ alumina crucible) to approximately $2 / 3$ full (between 60 and $70 \mathrm{~mL}$ ). The exact amount is calculated by a formula given in the latest revision of the REDOX procedure $^{11}$ and is provided for each sample in the associated electronic laboratory notebook (ELN). The sludge/frit mixture in the crucible is dried in a $50 \pm 5{ }^{\circ} \mathrm{C}$ oven until it reaches a water mass loss of $\sim 90$ $95 \%$. The dried sludge is then stirred to homogeneity and the lid is sealed onto the crucible using a nepheline $\left(\mathrm{NaAlSiO}_{4}\right)$ gel. The gel is dried and the crucible is preheated at $70{ }^{\circ} \mathrm{C}$ for at least $30-45$ minutes to prevent thermal shock. The preheated crucible is placed on the elevator platform of the bottom loading furnace in Cell 1 and raised into the preheated chamber at $1150{ }^{\circ} \mathrm{C}$. Once the oven recovers temperature from the process of inserting a crucible, the sample is held for one hour and then removed to a pan to quench cool in air. The furnace is allowed to recover to temperature during the period that it is empty between processing samples. When all samples have been vitrified and cooled, the glass is broken out of the crucible and pieces are isolated from the interior of the glass, away from the surface exposed to the atmosphere or the surface in contact with the alumina crucible. The surface and interior faces of the remaining glass are imaged via optical microscope to examine the glass homogeneity and extent of crystallization. The select interior glass samples are analyzed for REDOX measurements according to the latest revision of the REDOX procedure. ${ }^{11}$

To aid in the formation of homogeneous glass, the viscosity of the melts are predicted utilizing a viscosity model and composition. According to procedure, the viscosity for ideal convection is $<50-60$ poise. The calculated viscosity at $1150^{\circ} \mathrm{C}$ for SC-18 was $\sim 62$ poise. Lithium metaborate was added as a flux to reduce the viscosity to of SC-18 to $\sim 41$ poise. Lithium metaborate only impacts the viscosity and does not impact the overall REDOX of the mixture.

The accepted glass samples were dissolved following the Baumann methodology and colorimetrically analyzed with a fiber optic-connected UV/Vis spectrometer. ${ }^{12}$ The UV/Vis cuvette holder cell with attached fiber optic cables was located inside Cell 6 while the spectrometer and control computer were located outside of Cell 6 while the spectrometer and control computer were located outside of Cell 6. All required dissolution and analysis reagents were individually measured and prepared outside of the Shielded Cells by the Process Science Analytical Laboratory (PSAL).

\subsection{Quality Assurance}

Requirements for performing reviews of technical reports and the extent of review are established in manual E7 2.60. SRNL documents the extent and type of review using the SRNL Technical Report Design Checklist contained in WSRC-IM-2002-00011, Rev. 2. Design verification by document review was performed by F.C. Johnson for Sections 2.6 and 3.6 and by W.H. Woodham for the balance of the report. PCT evaluation was performed in accordance with RW-0333P. 
Details of various portions of the experiments are contained in the following Electronic Laboratory Notebooks (ELN):

- C. J. Martino, "NG-SB9 Intermediate Sample Analysis", ELN experiment A6583-00142-11.

- J. D. Newell, Metal Solubility of SC-18 SRAT Product", ELN experiment c7605-00021-12.

- C. L. Crawford, "DWPF SB9 SC18 AltRed Product Consistency Test PCT", ELN experiment B9108-00026-34.

- M. S. Williams, "SB9 Shielded Cells Qualification - SC-18 REDOX”, ELN experiment i777000157-15.

\subsection{Results and Discussion}

\subsection{Slurry Organic Analysis}

Table 3-1 shows the SVOA and VOA analytical result for the SRAT receipt, SRAT product, and SME product. The VOA results for the SRAT receipt and SME product were reported previously. ${ }^{2}$ Plasticizers were noted by SVOA analysis, but this was due to plastics used to store samples at SRNL and are thus not reported here. All values are below detectable levels. Propanal and TMS are bounded by the detection limit for VOA; and HMDSO and TMS are bounded by the detection limit for SVOA.

Table 3-1. Results from Slurry Organics Analyses

\begin{tabular}{|l|c|c||}
\hline Process step & $\begin{array}{c}\text { SVOA } \\
\text { (mg/kg slurry) }\end{array}$ & $\begin{array}{c}\text { VOA } \\
\text { (mg/kg slurry) }\end{array}$ \\
\hline SRAT Receipt & $<16$ & $<8.4$ (Ref. 2) \\
\hline SRAT Product & $<10$ & $<6.1$ \\
\hline SME Product & $<11$ & $<6.2$ (Ref. 2) \\
\hline
\end{tabular}

\section{2 $\underline{\text { Condensate Samples }}$}

Table 3-2 contains the results of the analysis condensate samples. Previously, anion and ammonium content was reported for many of these samples. This analysis includes mercury and ADPs.

Highest mercury concentrations were noted in the condensate early in the SRAT ( $405 \mathrm{mg} / \mathrm{L}$ at initial heat to boiling). Samples of condensate taken at the end of the dewater period in the SRAT matched well with the mercury concentration at the end of the reflux period (approximately $160 \mathrm{mg} / \mathrm{L}$ ). During the SME, a lower but consistent mercury concentration was noted throughout the canister decontamination dewaters and frit addition dewaters (13 to $24 \mathrm{mg} / \mathrm{L}$ ). No direct comparison to the SB9 simulant run with a similar acid addition is available for mercury in the condensate.

HMDSO was below the detectable level of $0.25 \mathrm{mg} / \mathrm{L}$ in all condensate samples measured by SVOA or VOA. TMS was measured in the condensate samples from late in the SRAT cycle (SRAT dewater composite and end of reflux sample) and throughout the SME cycle, ranging from 11 to $62 \mathrm{mg} / \mathrm{L}$ when above the $0.25 \mathrm{mg} / \mathrm{L}$ detection limit. Propanal was quantified at levels just above the $0.25 \mathrm{mg} / \mathrm{L}$ detection limit $(0.27$ and $0.34 \mathrm{mg} / \mathrm{L})$ for two of the nine dewater samples collected during the SME cycle. These 
results are consistent with simulant runs SB9-NG60 through NG62, where TMS was noted late in the SRAT and in the SME and propanal was seen exclusively in the SME condensates. ${ }^{10}$

Table 3-2. Condensate Sample Results for Mercury and ADPs

\begin{tabular}{|l|c|c|c|c||}
\hline Process step & $\begin{array}{c}\text { Hg } \\
\mathbf{( m g} / \mathbf{L})\end{array}$ & $\begin{array}{c}\text { TMS } \\
\mathbf{( m g} / \mathbf{L})\end{array}$ & $\begin{array}{c}\text { propanal } \\
\mathbf{( m g} / \mathbf{L})\end{array}$ & $\begin{array}{c}\text { HMDSO } \\
\mathbf{( m g} / \mathbf{L})\end{array}$ \\
\hline Heat to Boiling & $4.05 \mathrm{E}+02$ & $<2.5 \mathrm{E}-01$ & - & $<2.5 \mathrm{E}-01$ \\
\hline End of Dewater & $1.57 \mathrm{E}+02$ & $<2.5 \mathrm{E}-01$ & - & $<2.5 \mathrm{E}-01$ \\
\hline 30 min Prior to End of Reflux & $1.58 \mathrm{E}+02$ & $1.1 \mathrm{E}+01$ & - & $<2.5 \mathrm{E}-01$ \\
\hline SRAT Dewater Composite & $6.86 \mathrm{E}+01$ & $1.5 \mathrm{E}+01$ & $<2.5 \mathrm{E}-01$ & $<2.5 \mathrm{E}-01$ \\
\hline SRAT Ice Cube & - & $<2.5 \mathrm{E}-01$ & $<2.5 \mathrm{E}-01$ & $<2.5 \mathrm{E}-01$ \\
\hline Canister Decon. Dewater 1 & $1.37 \mathrm{E}+01$ & $5.3 \mathrm{E}+01$ & $<2.5 \mathrm{E}-01$ & $<2.5 \mathrm{E}+01$ \\
\hline Canister Decon. Dewater 2 & $1.32 \mathrm{E}+01$ & $4.1 \mathrm{E}+01$ & $<2.5 \mathrm{E}-01$ & $<2.5 \mathrm{E}+01$ \\
\hline Canister Decon. Dewater 3 & $1.81 \mathrm{E}+01$ & $4.1 \mathrm{E}+01$ & $<2.5 \mathrm{E}-01$ & $<2.5 \mathrm{E}+01$ \\
\hline Canister Decon. Dewater 4 & $1.95 \mathrm{E}+01$ & $3.7 \mathrm{E}+01$ & $<2.5 \mathrm{E}-01$ & $<2.5 \mathrm{E}+01$ \\
\hline Canister Decon. Dewater 5 & $2.31 \mathrm{E}+01$ & $4.0 \mathrm{E}+01$ & $2.7 \mathrm{E}-01$ & $<2.5 \mathrm{E}+01$ \\
\hline Canister Decon. Dewater 6 & $2.47 \mathrm{E}+01$ & $6.2 \mathrm{E}+01$ & $<2.5 \mathrm{E}-01$ & $<2.5 \mathrm{E}+01$ \\
\hline Frit Dewater 1 & $1.44 \mathrm{E}+01$ & $3.3 \mathrm{E}+01$ & $3.4 \mathrm{E}-01$ & $<2.5 \mathrm{E}+01$ \\
\hline Frit Dewater 2 & $1.29 \mathrm{E}+01$ & $4.0 \mathrm{E}+01$ & $<2.5 \mathrm{E}-01$ & $<2.5 \mathrm{E}+01$ \\
\hline Final Dewater & $1.77 \mathrm{E}+01$ & $2.1 \mathrm{E}+01$ & $<2.5 \mathrm{E}-01$ & $<2.5 \mathrm{E}+01$ \\
\hline SME Ice Cube & - & $1.4 \mathrm{E}+00$ & - & $<2.5 \mathrm{E}+01$ \\
\hline \hline
\end{tabular}

\subsection{Intermediate Slurry Samples}

Samples were taken specifically for mercury analysis, and the averages and \%RSD for the mercury results are presented in Table 3-3. Multiple small samples were taken at various processing times and the samples were dissolved by AR in their entirety to avoid potential error caused by inhomogeneities during sub-sampling. Also included are the SRAT receipt and the SRAT product analyses from the previous characterization. SRAT receipt and post glycolic acid addition samples were both sampled prior to steam stripping, so they likely should match mercury concentration if adjusting for the change in volume. However, reduction occurred prior to the post glycolic acid addition samples and that might have impacted the ability to obtain representative samples. The three individual end of SRAT samples matched well with the analysis of the larger SRAT product sample that was reported previously. 
Table 3-3. Slurry Mercury Concentration during SRAT Processing

\begin{tabular}{|l|c|c||}
\hline Stage of SRAT process & Hg, $\mathbf{m g} / \mathbf{k g}$ slurry & \%RSD, $\mathbf{n}$ \\
\hline SRAT Receipt * & $3.84 \mathrm{E}+03$ & $6.5 \%, 4$ \\
\hline Post Glycolic Acid Addition & $3.22 \mathrm{E}+03$ & $0.4 \%, 2$ \\
\hline Start of Reflux & $3.31 \mathrm{E}+03$ & $1.3 \%, 2$ \\
\hline 8.0 hrs into Reflux & $2.71 \mathrm{E}+03$ & $1.6 \%, 2$ \\
\hline End of SRAT & $1.70 \mathrm{E}+03$ & $1.6 \%, 3$ \\
\hline SRAT Product * & $1.74 \mathrm{E}+03$ & $2.1 \%, 4$ \\
\hline
\end{tabular}

* from previous report. $^{2}$

Figure 3-1 contains a plot of the mercury sample concentration versus the amount of conflux in the SRAT. Although there is discrepancy between the two measurements prior to conflux (the SRAT receipt and the post glycolic acid addition samples), the intermediate and final mercury samples are consistent with the linear stripping of mercury during conflux. The slope of the linear fit of the sample analysis is 77.2 $\mathrm{mg} / \mathrm{kg} / \mathrm{hr}$. Based on the feed mass, this corresponds to $4.460 \mathrm{mg}$ of mercury stripped per minute of conflux. Conflux was at a constant rate of $5.14 \mathrm{~g} / \mathrm{min}$ of condensate collected (or $5.14 \mathrm{~g} / \mathrm{min}$ of steam used). The mass of conflux is assumed to approximate the amount of steam required assuming no heat losses in the system. Based on this conflux rate, mercury stripping required an average of approximately 1000 grams of steam per gram of mercury stripped. This is higher than the 750 grams of steam per gram of mercury that was used in the assumption to set the total conflux time. From Figure 3-2, mercury removal during dewater required approximately 300 grams of steam per gram of mercury stripped, while mercury removal during reflux required approximately 1400 grams of steam per gram of mercury stripped.

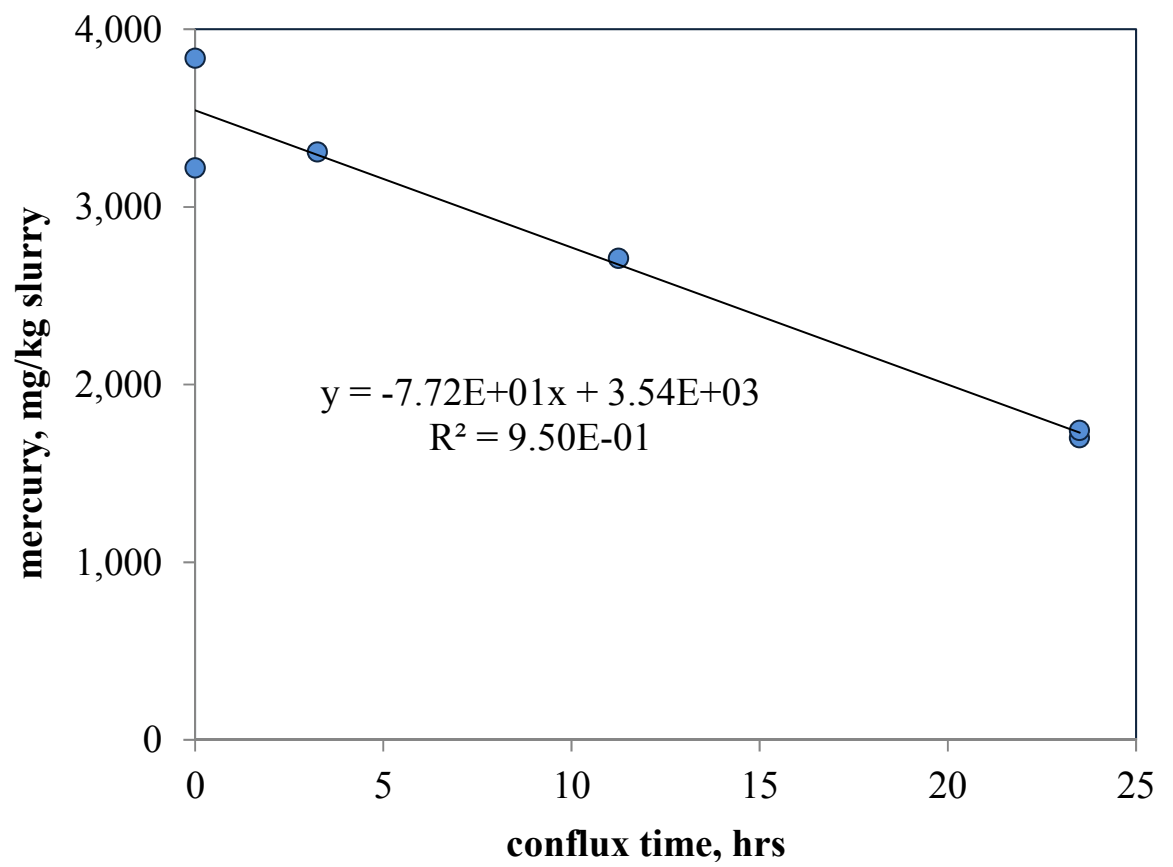

Figure 3-1. Mercury Concentration in Slurry Samples, Indicating Mercury Stripping during the SC-18 SRAT Cycle 
SRNL-STI-2016-00726

Revision 0

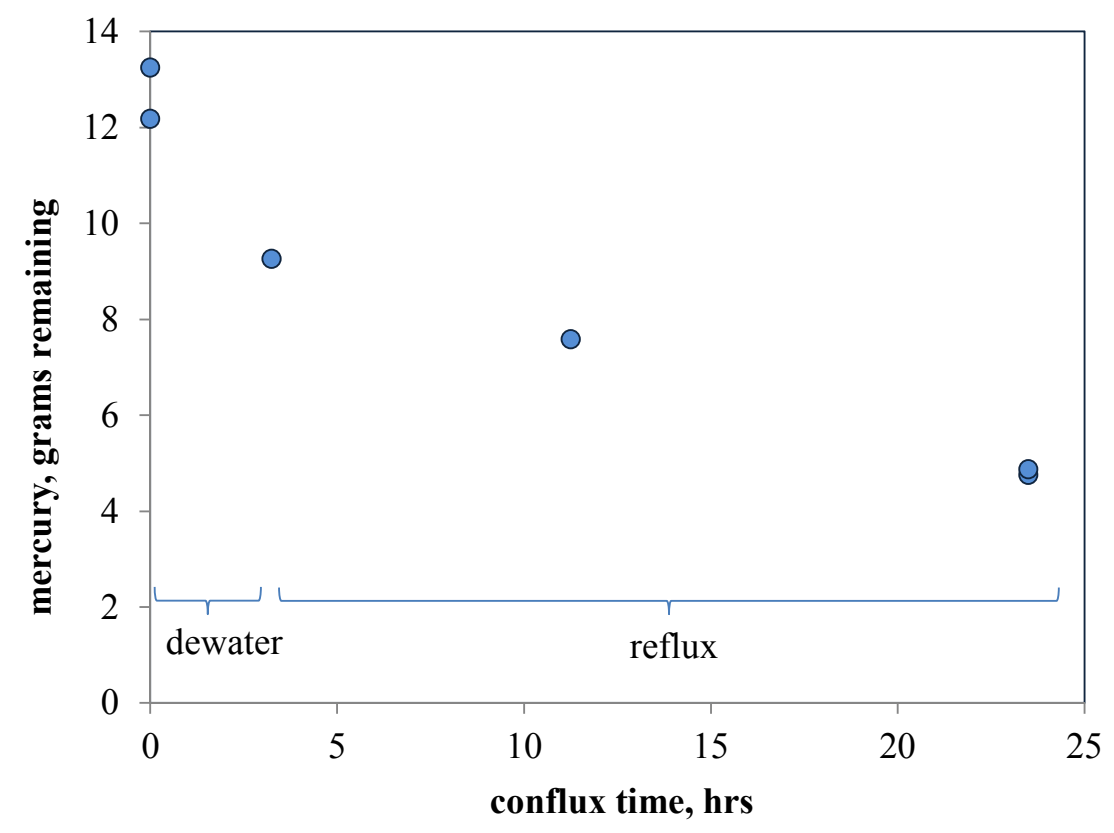

Figure 3-2. Estimated Mercury Remaining in Slurry During SC-18 SRAT Cycle

Intermediate SRAT slurry samples taken throughout the run showed a gradual removal of nitrite to approximately $2000 \mathrm{mg} / \mathrm{kg}$ in the slurry sample after 13 hours of conflux and $300 \mathrm{mg} / \mathrm{kg}$ in the SRAT product sample after 24 hours of conflux. Table 3-4 contains the analysis of the CQ samples for anions. In Figure 3-3, nitrite decomposition can be seen throughout the run through the slurry and soluble nitrite results. Both sets of results follow the same general trend of nitrite being gradually reduced throughout the run, where the slurry and soluble concentration of nitrite remained above $1000 \mathrm{mg} / \mathrm{kg}$ in the 10 hour reflux sample before falling to below $1000 \mathrm{mg} / \mathrm{kg}$ in the SRAT product sample. This persistent nitrite concentration may be due to the relatively low acid stoichiometry used in run SC-18. For the nitric-formic flowsheet, nitrite concentration in the SRAT product is required to be less than $1000 \mathrm{mg} / \mathrm{kg}$ in order to limit catalytic hydrogen generation in the SME, which has a lower purge rate. Such a requirement may not be necessary for the nitric-glycolic flowsheet due to overall low amount of catalytic hydrogen generation. Note that the soluble nitrite in the post glycolic acid addition sample appears to be an outlier. Figure 3-4 contains the trend in several of the other slurry anions as a function of conflux time. Some variations in anions were notable in CQ intermediate samples. Some of these variations can be due to analytical uncertainty and the differences in sample handling and storage time prior to analysis for the intermediate and SRAT product samples. 
SRNL-STI-2016-00726

Revision 0

Table 3-4. Anion Concentration During SRAT Processing (mg/kg of Slurry)

\begin{tabular}{|c|c|c|c|c|c|c|c|c|}
\hline Analyte & $\begin{array}{c}\text { SRAT } \\
\text { Receipt }\end{array}$ & $\begin{array}{c}\text { Mid } \\
\text { Glycolic } \\
\text { Acid } \\
\text { Addition }\end{array}$ & $\begin{array}{c}\text { Post } \\
\text { Glycolic } \\
\text { Acid } \\
\text { Addition }\end{array}$ & $\begin{array}{l}1.5 \text { hrs into } \\
\text { Dewater }\end{array}$ & $\begin{array}{l}3.0 \text { hrs into } \\
\text { Dewater }\end{array}$ & $\begin{array}{l}5.0 \text { hrs into } \\
\text { Reflux }\end{array}$ & $\begin{array}{c}10.0 \text { hrs } \\
\text { into Reflux }\end{array}$ & $\begin{array}{c}\text { SRAT } \\
\text { Product }\end{array}$ \\
\hline Fluoride & $<3.30 \mathrm{E}+02$ & $<5.31 \mathrm{E}+02$ & $<6.05 \mathrm{E}+02$ & $<5.49 \mathrm{E}+02$ & $<5.75 \mathrm{E}+02$ & $<5.76 \mathrm{E}+02$ & $<6.05 \mathrm{E}+02$ & - \\
\hline Formate & $<3.30 \mathrm{E}+02$ & $1.27 \mathrm{E}+03$ & $2.41 \mathrm{E}+03$ & $1.94 \mathrm{E}+03$ & $1.94 \mathrm{E}+03$ & $2.95 \mathrm{E}+03$ & $3.40 \mathrm{E}+03$ & $1.45 \mathrm{E}+03$ \\
\hline Chloride & $<3.30 \mathrm{E}+02$ & $<5.31 \mathrm{E}+02$ & $<6.05 \mathrm{E}+02$ & $<5.49 \mathrm{E}+02$ & $<5.75 \mathrm{E}+02$ & $<5.76 \mathrm{E}+02$ & $<6.05 \mathrm{E}+02$ & - \\
\hline Nitrite & $1.20 \mathrm{E}+04$ & $1.26 \mathrm{E}+04$ & $8.73 \mathrm{E}+03$ & $4.52 \mathrm{E}+03$ & $3.94 \mathrm{E}+03$ & $2.68 \mathrm{E}+03$ & $1.96 \mathrm{E}+03$ & $3.04 \mathrm{E}+02$ \\
\hline Nitrate & $6.92 \mathrm{E}+03$ & $2.85 \mathrm{E}+04$ & $2.97 \mathrm{E}+04$ & $3.50 \mathrm{E}+04$ & $4.19 \mathrm{E}+04$ & $4.11 \mathrm{E}+04$ & $3.92 \mathrm{E}+04$ & $4.10 \mathrm{E}+04$ \\
\hline Phosphate & $<3.30 \mathrm{E}+02$ & $<5.31 \mathrm{E}+02$ & $<6.05 \mathrm{E}+02$ & $<5.49 \mathrm{E}+02$ & $<5.75 \mathrm{E}+02$ & $<5.76 \mathrm{E}+02$ & $<6.05 \mathrm{E}+02$ & $<6.35 \mathrm{E}+02$ \\
\hline Oxalate & $2.43 \mathrm{E}+03$ & $2.01 \mathrm{E}+03$ & $2.98 \mathrm{E}+03$ & $2.68 \mathrm{E}+03$ & $2.05 \mathrm{E}+03$ & $4.97 \mathrm{E}+03$ & $6.73 \mathrm{E}+03$ & $4.79 \mathrm{E}+03$ \\
\hline Bromide & $<1.70 \mathrm{E}+03$ & $<5.31 \mathrm{E}+02$ & $<6.05 \mathrm{E}+02$ & $<5.49 \mathrm{E}+02$ & $<5.75 \mathrm{E}+02$ & $<5.76 \mathrm{E}+02$ & $<6.05 \mathrm{E}+02$ & $<6.35 \mathrm{E}+02$ \\
\hline Glycolate & $<2.20 \mathrm{E}+03$ & $2.83 \mathrm{E}+03$ & $2.74 \mathrm{E}+04$ & $3.23 \mathrm{E}+04$ & $4.28 \mathrm{E}+04$ & $3.53 \mathrm{E}+04$ & $3.24 \mathrm{E}+04$ & $3.71 \mathrm{E}+04$ \\
\hline
\end{tabular}

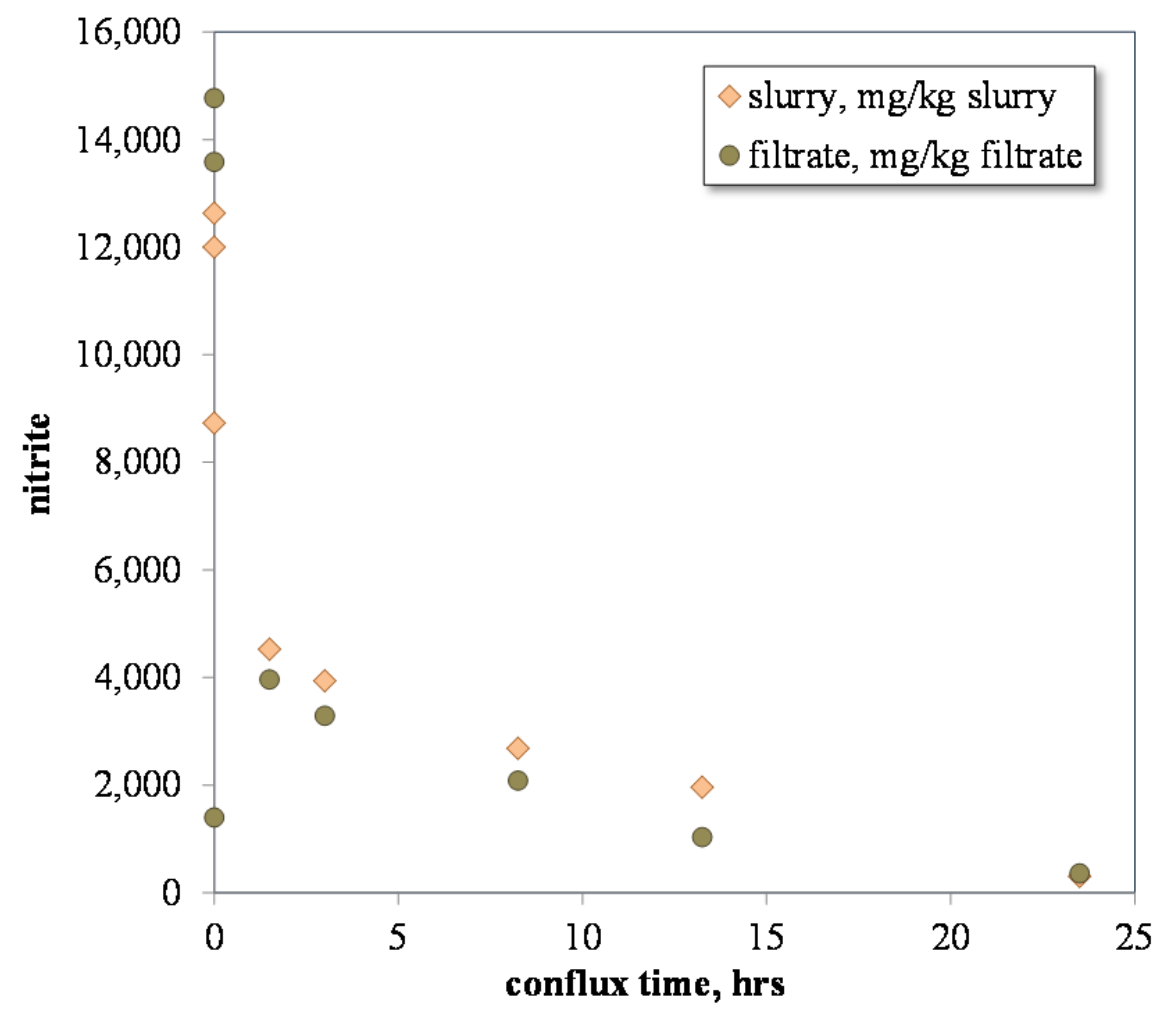

Figure 3-3. Nitrite Decomposition During the SC-18 SRAT Cycle 
SRNL-STI-2016-00726

Revision 0

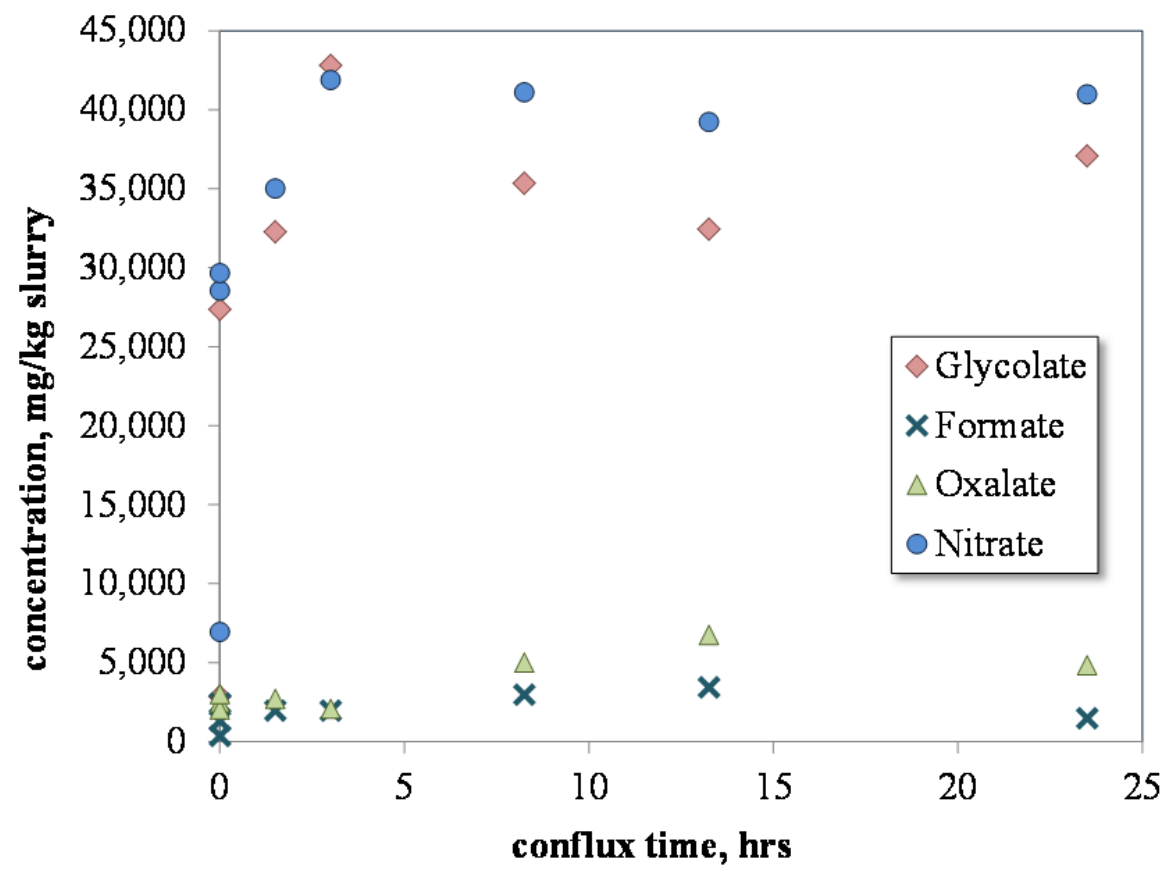

Figure 3-4. Anion Concentration in Slurry Samples from the SC-18 SRAT Cycle

Table 3-5 and Table 3-6 contain the results for intermediate samples that were filtered prior to preparation and analysis. These results correspond to what supernatant would look like at various stages of processing. The filtrate from the SRAT receipt and SRAT product from the previous report ${ }^{2}$ are included with the results for comparison. Based on the plutonium isotopics in the feed, the Pu-239 measurements would need to be multiplied by a factor of 1.20 to represent total plutonium.

Assuming no dissolution or precipitation, components are diluted during acid addition due to the additional volume added, components get concentrated during dewater due to the water volume removed, and components stay relatively constant during reflux. Some components such as sulfate show this trend of dilution and concentration. Other components have different concentration profiles, showing that they are either formed, decomposed, dissolved, or precipitated. Nitrate and glycolate increase during acid addition and nitrite is seen disappearing during dewater and reflux. Components such as manganese and magnesium have an increased solubility during acid addition and remain soluble throughout conflux. Some components have a portion come into solution during acid addition and gradually precipitate during dewater and reflux. This is encountered for iron, uranium, and plutonium, and to a lesser extend for many of the other metals. Figure 3-5 shows the trend of supernatant concentrations for several metals versus the conflux time, starting from the post glycolic acid addition filtrate sample through the SRAT product filtrate sample. Due to the $\mathrm{pH}$ change during processing, the figure demonstrates the precipitation of iron, uranium, and plutonium during SC-18. Manganese shows only a small amount of precipitation during SRAT processing in spite of the $\mathrm{pH}$ change. 
Table 3-5. Metal and Isotope Concentration in Filtrate ( $\mathrm{mg} / \mathrm{kg}$ of Supernatant)

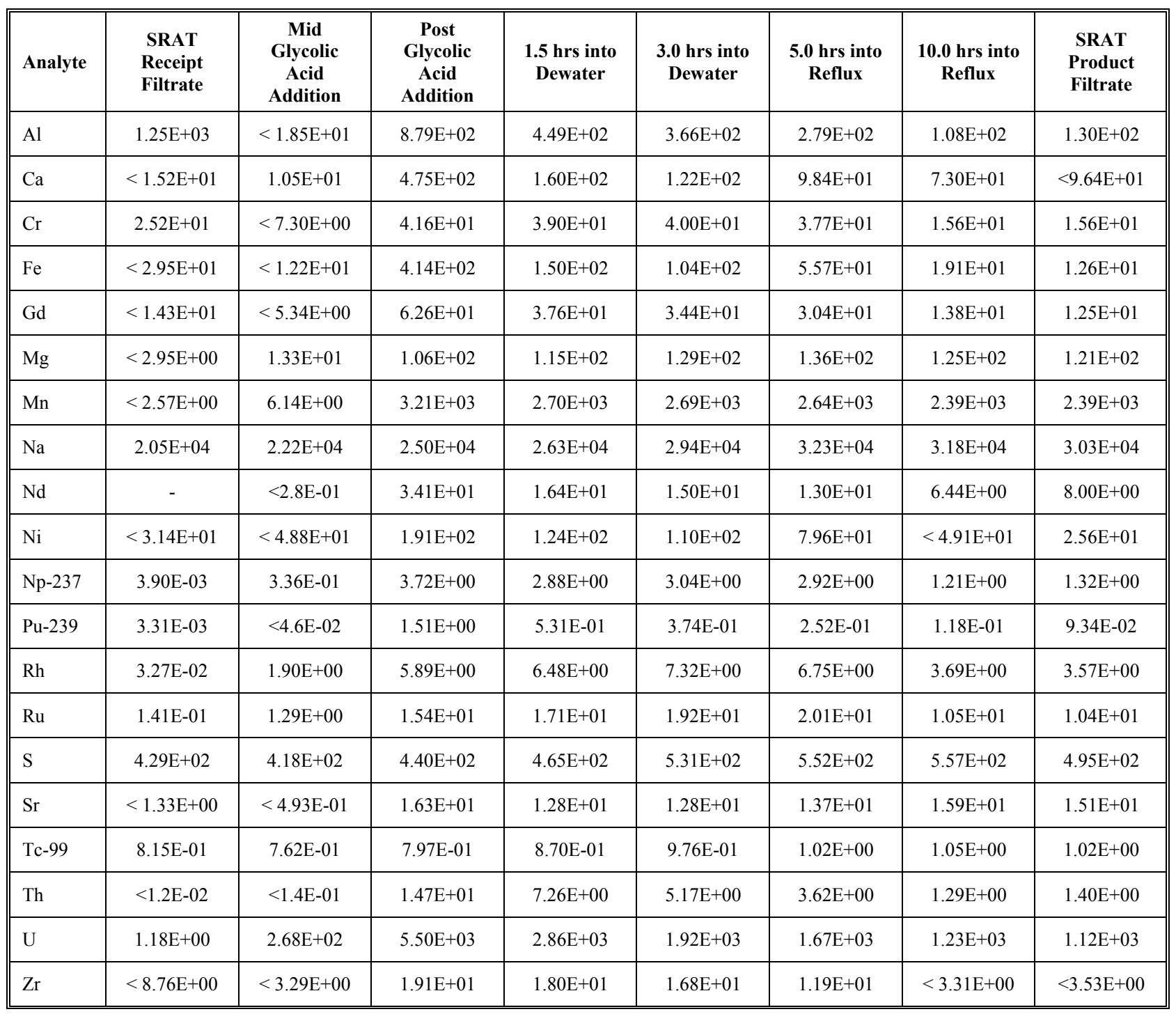


SRNL-STI-2016-00726

Revision 0

Table 3-6. Anion, TIC, and TOC Concentration in Filtrate (mg/kg of Supernatant)

\begin{tabular}{|c|c|c|c|c|c|c|c|c|c|}
\hline Analyte & Units & $\begin{array}{c}\text { SRAT } \\
\text { Receipt } \\
\text { Filtrate }\end{array}$ & $\begin{array}{c}\text { Mid } \\
\text { Glycolic } \\
\text { Acid } \\
\text { Addition }\end{array}$ & $\begin{array}{c}\text { Post } \\
\text { Glycolic } \\
\text { Acid } \\
\text { Addition }\end{array}$ & $\begin{array}{l}1.5 \text { hrs into } \\
\text { Dewater }\end{array}$ & $\begin{array}{c}3.0 \text { hrs into } \\
\text { Dewater }\end{array}$ & $\begin{array}{l}5.0 \text { hrs into } \\
\text { Reflux }\end{array}$ & $\begin{array}{c}10.0 \text { hrs } \\
\text { into Reflux }\end{array}$ & $\begin{array}{c}\text { SRAT } \\
\text { Product } \\
\text { Filtrate }\end{array}$ \\
\hline Fluoride & $\mathrm{mg} / \mathrm{kg}$ & $<2.5 \mathrm{E}+02$ & $<4.9 \mathrm{E}+02$ & $<4.7 \mathrm{E}+02$ & $<4.3 \mathrm{E}+02$ & $<4.4 \mathrm{E}+02$ & $<4.7 \mathrm{E}+02$ & $<4.5 \mathrm{E}+02$ & $<1.2 \mathrm{E}+03$ \\
\hline Formate & $\mathrm{mg} / \mathrm{kg}$ & $<2.5 \mathrm{E}+02$ & $<4.9 \mathrm{E}+02$ & $1.10 \mathrm{E}+03$ & $1.04 \mathrm{E}+03$ & $1.42 \mathrm{E}+03$ & $1.79 \mathrm{E}+03$ & $2.14 \mathrm{E}+03$ & $1.63 \mathrm{E}+03$ \\
\hline Chloride & $\mathrm{mg} / \mathrm{kg}$ & $<2.5 \mathrm{E}+02$ & $<4.9 \mathrm{E}+02$ & $<4.7 \mathrm{E}+02$ & $<4.3 \mathrm{E}+02$ & $<4.4 \mathrm{E}+02$ & $<4.7 \mathrm{E}+02$ & $<4.5 \mathrm{E}+02$ & $<1.2 \mathrm{E}+02$ \\
\hline Nitrite & $\mathrm{mg} / \mathrm{kg}$ & $1.36 \mathrm{E}+04$ & $1.48 \mathrm{E}+04$ & $1.39 \mathrm{E}+03$ & $3.96 \mathrm{E}+03$ & $3.29 \mathrm{E}+03$ & $2.08 \mathrm{E}+03$ & $1.03 \mathrm{E}+03$ & $3.60 \mathrm{E}+02$ \\
\hline Nitrate & $\mathrm{mg} / \mathrm{kg}$ & $7.91 \mathrm{E}+03$ & $3.79 \mathrm{E}+04$ & $4.11 \mathrm{E}+04$ & $3.79 \mathrm{E}+04$ & $4.56 \mathrm{E}+04$ & $4.83 \mathrm{E}+04$ & $4.62 \mathrm{E}+04$ & $4.95 \mathrm{E}+04$ \\
\hline Phosphate & $\mathrm{mg} / \mathrm{kg}$ & $<2.5 \mathrm{E}+02$ & $<4.9 \mathrm{E}+02$ & $<4.7 \mathrm{E}+02$ & $<4.3 \mathrm{E}+02$ & $<4.4 \mathrm{E}+02$ & $<4.7 \mathrm{E}+02$ & $<4.5 \mathrm{E}+02$ & $<1.2 \mathrm{E}+02$ \\
\hline Sulfate & $\mathrm{mg} / \mathrm{kg}$ & $1.20 \mathrm{E}+03$ & $1.25 \mathrm{E}+03$ & $1.01 \mathrm{E}+03$ & $1.18 \mathrm{E}+03$ & $1.41 \mathrm{E}+03$ & $1.47 \mathrm{E}+03$ & $1.42 \mathrm{E}+03$ & $1.42 \mathrm{E}+03$ \\
\hline Oxalate & $\mathrm{mg} / \mathrm{kg}$ & $2.71 \mathrm{E}+03$ & $8.81 \mathrm{E}+02$ & $1.59 \mathrm{E}+03$ & $1.12 \mathrm{E}+03$ & $1.42 \mathrm{E}+03$ & $1.59 \mathrm{E}+03$ & $1.96 \mathrm{E}+03$ & $2.57 \mathrm{E}+03$ \\
\hline Bromide & $\mathrm{mg} / \mathrm{kg}$ & $<1.2 \mathrm{E}+03$ & $<4.9 \mathrm{E}+02$ & $<4.7 \mathrm{E}+02$ & $<4.3 \mathrm{E}+02$ & $<4.4 \mathrm{E}+02$ & $<4.7 \mathrm{E}+02$ & $<4.5 \mathrm{E}+02$ & $<6.2 \mathrm{E}+02$ \\
\hline Glycolate & $\mathrm{mg} / \mathrm{kg}$ & $<5.0 \mathrm{E}+02$ & $8.84 \mathrm{E}+03$ & $3.37 \mathrm{E}+04$ & $3.31 \mathrm{E}+04$ & $4.12 \mathrm{E}+04$ & $3.97 \mathrm{E}+04$ & $3.81 \mathrm{E}+04$ & $3.70 \mathrm{E}+04$ \\
\hline TIC & $\mathrm{mg} \mathrm{C} / \mathrm{kg}$ & - & $3.03 \mathrm{E}+01$ & $1.87 \mathrm{E}+01$ & $3.16 \mathrm{E}+01$ & $4.83 \mathrm{E}+01$ & $5.93 E+01$ & $8.94 \mathrm{E}+01$ & $2.12 \mathrm{E}+02$ \\
\hline TOC & $\mathrm{mg} \mathrm{C} / \mathrm{kg}$ & - & $2.54 \mathrm{E}+03$ & $1.07 \mathrm{E}+04$ & $1.17 \mathrm{E}+04$ & $1.36 \mathrm{E}+04$ & $1.40 \mathrm{E}+04$ & $1.38 \mathrm{E}+04$ & $1.43 \mathrm{E}+04$ \\
\hline
\end{tabular}

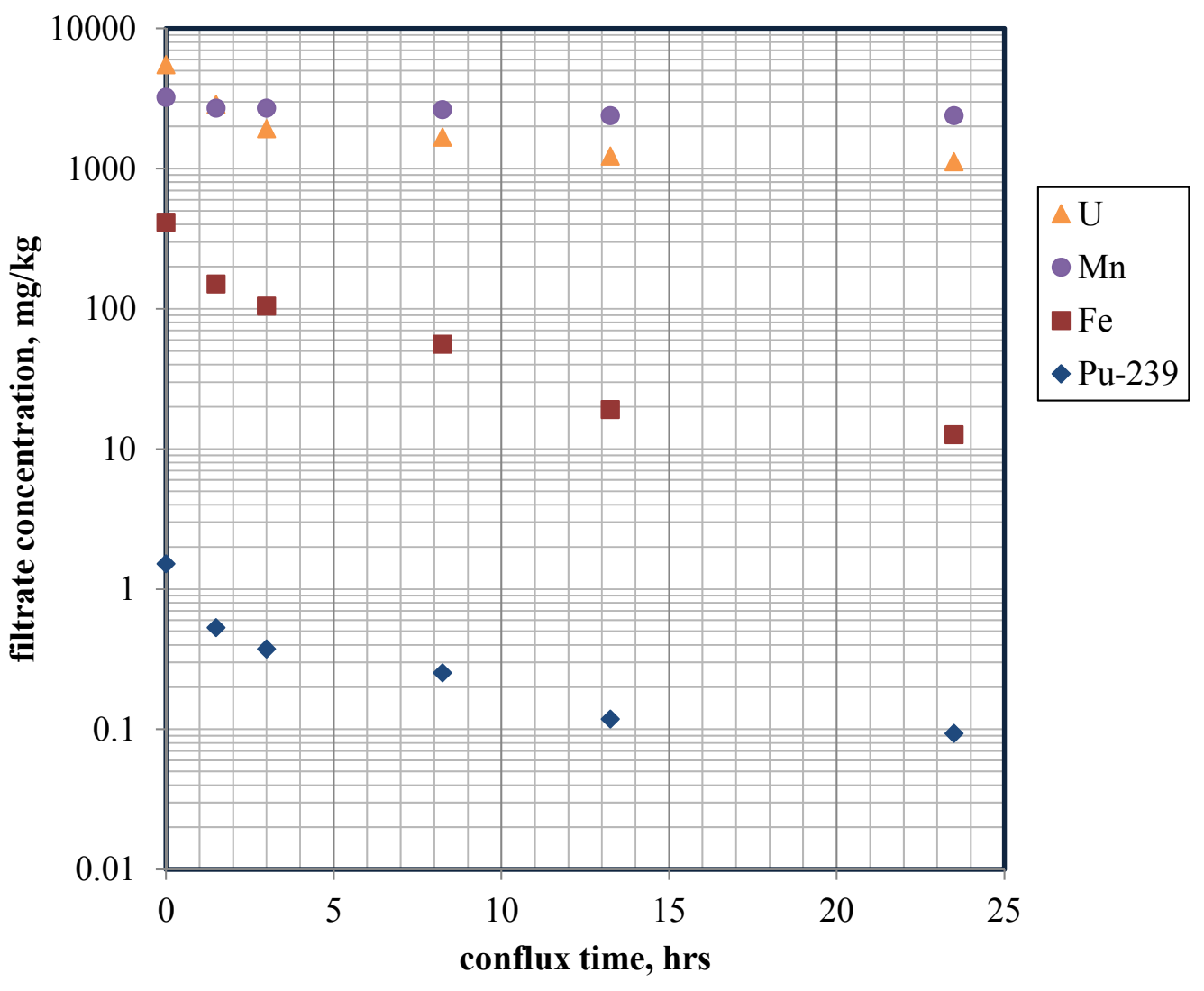

Figure 3-5. Soluble Concentration of Select Metals Throughout the SC-18 SRAT Cycle 


\subsection{Metal Solubility Test}

The solids content of the $\mathrm{pH}$ adjusted slurries are given in Table 3-7. The dissolved solids of the slurries were measured. Total solids concentrations were calculated based on previously reported data. ${ }^{2}$ As acids are added to decrease the slurry $\mathrm{pH}$, the total solids of the slurries increase. The insoluble solids were determined by taking the difference between the total solids and soluble solid.

Table 3-7. Solids Contents of pH Adjusted SRAT Product

\begin{tabular}{|l|c|c|c||}
\hline \hline Measurement & pH 3 Slurry & pH 2 Slurry & pH 1 Slurry \\
\hline Total solids, wt\% of slurry & 29.0 & 30.0 & 30.6 \\
\hline Insoluble solids, wt\% of slurry & 10.2 & 12.1 & 13.5 \\
\hline Soluble solids, wt\% of slurry & 18.8 & 17.9 & 17.1 \\
\hline Dissolved solids, wt\% of supernatant & 20.9 & 20.4 & 19.8 \\
\hline
\end{tabular}

Concentrations of the elemental constituents in the SRAT product slurries are given in Table 3-8 and are on a total solids basis. As expected, the elemental concentrations decrease as $\mathrm{pH}$ decreases, due to the diluting effect of acid addition. For most cases, the results for the AR digested samples resulted in lower than expected values. Where possible, the PF digested sample results are reported.

Concentrations of the elemental constituents in the SRAT product supernatant are given in Table 3-9. The solubility of select elements in the SRAT product samples is presented in Table 3-10 and Table 3-11. Iron solubility in the SC-18 SRAT product was $0.03 \%$ and increases as $\mathrm{pH}$ decreases. As expected, uranium exhibits complete solubility at lower $\mathrm{pH}$ values when considering uncertainty. These solubility trends are generally consistent with data previously reported. ${ }^{13}$ 
Table 3-8. Elemental Analysis of the Slurry Solids $(n=4)$

\begin{tabular}{|c|c|c|c|c|c|c|c|}
\hline \multirow{2}{*}{ Analyte } & \multirow{2}{*}{$\begin{array}{c}\text { Digestion } \\
\text { Method }\end{array}$} & \multicolumn{2}{|c|}{ pH 3} & \multicolumn{2}{|c|}{ pH 2} & \multicolumn{2}{|c|}{ pH 1} \\
\hline & & wt.\% TS & $\%$ RSD & wt.\% TS & $\%$ RSD & wt.\% TS & $\%$ RSD \\
\hline $\mathrm{Ag}$ & AR & $<4.00 \mathrm{E}-03$ & NA & $<5.00 \mathrm{E}-03$ & NA & $<4.00 \mathrm{E}-03$ & NA \\
\hline $\mathrm{Al}$ & $\mathrm{PF}$ & $4.47 \mathrm{E}+00$ & 1.3 & $4.06 \mathrm{E}+00$ & 0.8 & $3.88 \mathrm{E}+00$ & 1.1 \\
\hline B & $\mathrm{AR}$ & $<1.40 \mathrm{E}-02$ & NA & $<1.50 \mathrm{E}-02$ & NA & $<1.40 \mathrm{E}-02$ & NA \\
\hline $\mathrm{Ba}$ & $\mathrm{PF}$ & $4.30 \mathrm{E}-02$ & 1.9 & $3.90 \mathrm{E}-02$ & 0.7 & $3.70 \mathrm{E}-02$ & 0.9 \\
\hline $\mathrm{Be}$ & AR & $<1.00 \mathrm{E}-03$ & NA & $<1.00 \mathrm{E}-03$ & NA & $<1.00 \mathrm{E}-03$ & NA \\
\hline $\mathrm{Ca}$ & $\mathrm{PF}$ & $8.18 \mathrm{E}-01$ & 3.6 & 7.12E-01 & 6.4 & $7.03 \mathrm{E}+00$ & 1.0 \\
\hline $\mathrm{Cd}$ & $\mathrm{AR}$ & $7.00 \mathrm{E}-03$ & 8.0 & $6.00 \mathrm{E}-03$ & 12.6 & $6.00 \mathrm{E}-03$ & 1.6 \\
\hline $\mathrm{Ce}$ & $\mathrm{AR}$ & $1.00 \mathrm{E}-01$ & 12 & 8.30E-02 & 14 & 8.70E-02 & 6.6 \\
\hline $\mathrm{Co}$ & $\mathrm{AR}$ & $<5.00 \mathrm{E}-03$ & NA & $<5.00 \mathrm{E}-03$ & NA & $<5.00 \mathrm{E}-03$ & NA \\
\hline $\mathrm{Cr}$ & $\mathrm{PF}$ & $5.30 \mathrm{E}-02$ & 1.1 & $4.80 \mathrm{E}-02$ & 1.7 & $4.70 \mathrm{E}-02$ & 1.6 \\
\hline $\mathrm{Cu}$ & $\mathrm{AR}$ & $<3.00 \mathrm{E}-02$ & NA & $<3.20 \mathrm{E}-02$ & NA & $<3.00 \mathrm{E}-02$ & NA \\
\hline $\mathrm{Fe}$ & $\mathrm{PF}$ & $1.01 \mathrm{E}+01$ & 1.0 & $9.17 \mathrm{E}+00$ & 0.8 & $8.70 \mathrm{E}+00$ & 1.1 \\
\hline $\mathrm{Gd}$ & $\mathrm{PF}$ & 4.40E-02 & 2.7 & $3.80 \mathrm{E}-02$ & 5.9 & $3.40 \mathrm{E}-02$ & 5.1 \\
\hline $\mathrm{Hg}$ & AR & $3.61 \mathrm{E}-01$ & 10 & $3.18 \mathrm{E}-01$ & 13 & $3.19 \mathrm{E}-01$ & 4.0 \\
\hline $\mathrm{K}$ & $\mathrm{AR}$ & $<8.60 \mathrm{E}-02$ & NA & $<9.10 \mathrm{E}-02$ & NA & $<8.40 \mathrm{E}-02$ & NA \\
\hline $\mathrm{La}$ & $\mathrm{PF}$ & $2.70 \mathrm{E}-02$ & 1.5 & $2.40 \mathrm{E}-02$ & 3.4 & $2.30 \mathrm{E}-02$ & 1.9 \\
\hline $\mathrm{Li}$ & $\mathrm{PF}$ & $2.80 \mathrm{E}-02$ & 3.0 & $2.60 \mathrm{E}-02$ & 3.2 & $2.50 \mathrm{E}-02$ & 2.7 \\
\hline $\mathrm{Mg}$ & $\mathrm{PF}$ & $1.39 \mathrm{E}-01$ & 1.1 & $1.23 \mathrm{E}-01$ & 2.1 & $2.50 \mathrm{E}-01$ & 2.7 \\
\hline $\mathrm{Mn}$ & $\mathrm{PF}$ & $3.21 \mathrm{E}+00$ & 1.1 & $2.88 \mathrm{E}+00$ & 1.0 & $2.74 \mathrm{E}+00$ & 0.8 \\
\hline Mo & $\mathrm{AR}$ & $<1.40 \mathrm{E}-02$ & NA & $<1.40 \mathrm{E}-02$ & NA & $<1.30 \mathrm{E}-02$ & NA \\
\hline $\mathrm{Na}$ & $\mathrm{AR}$ & $8.71 \mathrm{E}+00$ & 9.7 & $8.14 \mathrm{E}+00$ & 10.4 & $7.63 \mathrm{E}+00$ & 3.9 \\
\hline $\mathrm{Ni}$ & $\mathrm{PF}$ & 7.35E-01 & 1.6 & $6.62 \mathrm{E}-01$ & 0.7 & $6.25 \mathrm{E}-01$ & 1.1 \\
\hline $\mathrm{P}$ & $\mathrm{AR}$ & 7.20E-02 & 18 & $8.10 \mathrm{E}-02$ & 20 & 7.70E-02 & 12 \\
\hline $\mathrm{Pb}$ & $\mathrm{AR}$ & $<6.10 \mathrm{E}-02$ & NA & $<6.40 \mathrm{E}-02$ & NA & $<5.90 \mathrm{E}-02$ & NA \\
\hline $\mathrm{S}$ & $\mathrm{AR}$ & $1.66 \mathrm{E}-01$ & 9.4 & $1.48 \mathrm{E}-01$ & 9.6 & $1.41 \mathrm{E}-01$ & 2.9 \\
\hline $\mathrm{Sb}$ & $\mathrm{AR}$ & $<6.40 \mathrm{E}-02$ & NA & $<6.70 \mathrm{E}-02$ & NA & $<6.20 \mathrm{E}-02$ & NA \\
\hline $\mathrm{Si}$ & $\mathrm{PF}$ & $8.16 \mathrm{E}-01$ & 1.8 & 7.42E-01 & 1.2 & 7.00E-01 & 1.4 \\
\hline $\mathrm{Sn}$ & $\mathrm{AR}$ & $<3.80 \mathrm{E}-02$ & NA & $<4.00 \mathrm{E}-02$ & NA & $<3.70 \mathrm{E}-02$ & NA \\
\hline $\mathrm{Sr}$ & $\mathrm{PF}$ & $1.90 \mathrm{E}-02$ & 1.4 & $1.70 \mathrm{E}-02$ & 3.0 & $1.60 \mathrm{E}-02$ & 0.5 \\
\hline $\mathrm{Th}$ & $\mathrm{PF}$ & $5.58 \mathrm{E}-01$ & 2.7 & 4.83E-01 & 5.6 & 4.78E-01 & 1.7 \\
\hline $\mathrm{Ti}$ & $\mathrm{AR}$ & $<2.60 \mathrm{E}-02$ & NA & $<2.80 \mathrm{E}-02$ & NA & $<2.60 \mathrm{E}-02$ & NA \\
\hline $\mathrm{U}$ & $\mathrm{PF}$ & $2.07 \mathrm{E}+00$ & 1.4 & $1.80 \mathrm{E}+00$ & 2.8 & $1.71 \mathrm{E}+00$ & 0.6 \\
\hline $\mathrm{V}$ & $\mathrm{AR}$ & $<2.00 \mathrm{E}-03$ & NA & $<2.00 \mathrm{E}-03$ & NA & $<2.00 \mathrm{E}-03$ & NA \\
\hline $\mathrm{Zn}$ & $\mathrm{PF}$ & $1.70 \mathrm{E}-02$ & 4.9 & $1.50 \mathrm{E}-02$ & 3.9 & $1.40 \mathrm{E}-02$ & 2.7 \\
\hline $\mathrm{Zr}$ & $\mathrm{AR}$ & $2.30 \mathrm{E}-02$ & 20 & $1.80 \mathrm{E}-02$ & 99 & $2.90 \mathrm{E}-02$ & 36 \\
\hline
\end{tabular}


Table 3-9. Elemental Analysis of the Supernatant, mg/kg

\begin{tabular}{|c|c|c|c|c|c|c|}
\hline \multirow{2}{*}{ Constituent } & \multicolumn{2}{|c|}{ pH 3 Supernatant } & \multicolumn{2}{|c|}{ pH 2 Supernatant } & \multicolumn{2}{|c|}{ pH 1 Supernatant } \\
\hline & $\mathrm{mg} / \mathrm{kg}$ & $\%$ RSD & $\mathrm{mg} / \mathrm{kg}$ & $\%$ RSD & $\mathrm{mg} / \mathrm{kg}$ & $\%$ RSD \\
\hline $\mathrm{Ag}$ & $<1.53 \mathrm{E}+01$ & NA & $<1.47 \mathrm{E}+01$ & NA & $<1.40 \mathrm{E}+01$ & NA \\
\hline $\mathrm{Al}$ & $2.12 \mathrm{E}+03$ & 3.5 & $2.21 \mathrm{E}+03$ & 0.9 & $2.40 \mathrm{E}+03$ & 0.7 \\
\hline $\mathrm{B}$ & $<1.63 \mathrm{E}+01$ & NA & $<1.88 \mathrm{E}+01$ & NA & $<1.49 \mathrm{E}+01$ & NA \\
\hline $\mathrm{Ba}$ & $4.50 \mathrm{E}+00$ & 5.5 & $6.20 \mathrm{E}+00$ & 17 & $5.20 \mathrm{E}+00$ & 20 \\
\hline $\mathrm{Be}$ & $<4.00 \mathrm{E}-01$ & NA & $<4.00 \mathrm{E}-01$ & NA & $<4.00 \mathrm{E}-01$ & NA \\
\hline $\mathrm{Ca}$ & $4.32 \mathrm{E}+02$ & 4.7 & $8.95 \mathrm{E}+02$ & 0.8 & $1.26 \mathrm{E}+03$ & 1.3 \\
\hline $\mathrm{Cd}$ & $<1.39 \mathrm{E}+01$ & NA & $<1.33 \mathrm{E}+01$ & NA & $<1.27 \mathrm{E}+01$ & NA \\
\hline $\mathrm{Ce}$ & $<9.48 \mathrm{E}+01$ & NA & $<9.10 \mathrm{E}+01$ & NA & $<8.68 \mathrm{E}+01$ & NA \\
\hline Co & $<1.89 \mathrm{E}+01$ & NA & $<1.81 \mathrm{E}+01$ & NA & $<1.73 \mathrm{E}+01$ & NA \\
\hline $\mathrm{Cr}$ & $6.26 \mathrm{E}+01$ & 6.4 & $6.70 \mathrm{E}+01$ & 3.4 & $7.51 \mathrm{E}+01$ & 0.7 \\
\hline $\mathrm{Cu}$ & $<4.54 \mathrm{E}+01$ & NA & $<4.36 \mathrm{E}+01$ & NA & $<4.16 \mathrm{E}+01$ & NA \\
\hline $\mathrm{Fe}$ & $1.48 \mathrm{E}+03$ & 11 & $1.67 \mathrm{E}+03$ & 4.9 & $2.11 \mathrm{E}+03$ & 1 \\
\hline $\mathrm{Gd}$ & $8.54 \mathrm{E}+01$ & 4 & $8.49 \mathrm{E}+01$ & 1.8 & $9.88 \mathrm{E}+01$ & 1.2 \\
\hline $\mathrm{Hg}$ & $2.14 \mathrm{E}+02$ & 4 & $2.71 \mathrm{E}+02$ & 16 & $2.65 \mathrm{E}+02$ & 8.9 \\
\hline $\mathrm{K}$ & $<2.45 \mathrm{E}+02$ & NA & $<2.35 \mathrm{E}+02$ & NA & $<2.24 \mathrm{E}+02$ & NA \\
\hline $\mathrm{La}$ & $2.16 \mathrm{E}+01$ & 4.3 & $2.52 \mathrm{E}+01$ & 2.1 & $2.82 \mathrm{E}+01$ & 0.7 \\
\hline $\mathrm{Li}$ & $<3.05 \mathrm{E}+01$ & NA & $<2.93 \mathrm{E}+01$ & NA & $<2.94 \mathrm{E}+01$ & NA \\
\hline $\mathrm{Mg}$ & $1.62 \mathrm{E}+02$ & 5.3 & $1.78 \mathrm{E}+02$ & 3.2 & $2.21 \mathrm{E}+02$ & 0.8 \\
\hline $\mathrm{Mn}$ & $6.33 \mathrm{E}+03$ & 5.8 & $6.70 \mathrm{E}+03$ & 2 & $7.34 \mathrm{E}+03$ & 0.7 \\
\hline Mo & $<3.88 \mathrm{E}+01$ & NA & $<3.72 \mathrm{E}+01$ & NA & $<3.55 \mathrm{E}+01$ & NA \\
\hline $\mathrm{Na}$ & $2.94 \mathrm{E}+04$ & 2.3 & $2.76 \mathrm{E}+04$ & 0.4 & $2.67 \mathrm{E}+04$ & 0.6 \\
\hline $\mathrm{Ni}$ & $2.99 \mathrm{E}+02$ & 8.3 & $3.30 \mathrm{E}+02$ & 3.6 & $4.07 \mathrm{E}+02$ & 1.4 \\
\hline $\mathrm{P}$ & $<1.73 \mathrm{E}+02$ & NA & $<2.60 \mathrm{E}+02$ & NA & $<2.26 \mathrm{E}+02$ & NA \\
\hline $\mathrm{Pb}$ & $<1.72 \mathrm{E}+02$ & NA & $<1.65 \mathrm{E}+02$ & NA & $<1.58 \mathrm{E}+02$ & NA \\
\hline $\mathrm{S}$ & $4.67 \mathrm{E}+02$ & 3.4 & $4.33 \mathrm{E}+02$ & 2.7 & $4.15 \mathrm{E}+02$ & 1.7 \\
\hline $\mathrm{Sb}$ & $<3.55 \mathrm{E}+02$ & NA & $<3.41 \mathrm{E}+02$ & NA & $<3.25 \mathrm{E}+02$ & NA \\
\hline $\mathrm{Si}$ & $1.15 \mathrm{E}+03$ & 3.4 & $1.11 \mathrm{E}+03$ & 0.8 & $1.05 \mathrm{E}+03$ & 1.2 \\
\hline $\mathrm{Sn}$ & $<1.09 \mathrm{E}+02$ & NA & $<1.05 \mathrm{E}+02$ & NA & $<9.97 \mathrm{E}+01$ & NA \\
\hline $\mathrm{Sr}$ & $2.58 \mathrm{E}+01$ & 3.4 & $2.99 \mathrm{E}+01$ & 1 & $3.24 \mathrm{E}+01$ & 0.6 \\
\hline $\mathrm{Th}$ & $1.65 \mathrm{E}+02$ & 1.6 & $1.57 \mathrm{E}+02$ & 2 & $1.65 \mathrm{E}+02$ & 1.3 \\
\hline $\mathrm{Ti}$ & $<7.45 \mathrm{E}+01$ & NA & $<7.15 \mathrm{E}+01$ & NA & $<6.82 \mathrm{E}+01$ & NA \\
\hline $\mathrm{U}$ & $6.17 \mathrm{E}+03$ & 1.8 & $5.73 \mathrm{E}+03$ & 0.7 & $5.56 \mathrm{E}+03$ & 0.8 \\
\hline $\mathrm{V}$ & $<5.80 \mathrm{E}+00$ & NA & $<5.60 \mathrm{E}+00$ & NA & $<5.30 \mathrm{E}+00$ & NA \\
\hline $\mathrm{Zn}$ & $<1.87 \mathrm{E}+01$ & NA & $<1.80 \mathrm{E}+01$ & NA & $<1.71 \mathrm{E}+01$ & NA \\
\hline $\mathrm{Zr}$ & $2.05 \mathrm{E}+01$ & 5.4 & $2.20 \mathrm{E}+01$ & 1.8 & $2.41 \mathrm{E}+01$ & 1 \\
\hline
\end{tabular}


SRNL-STI-2016-00726

Revision 0

Table 3-10. Percent Solubility of Elements Measured by ICP-ES

\begin{tabular}{|c|c|c|c|c|}
\hline & $\begin{array}{c}\text { SC-18 SRAT } \\
\text { Product, pH 7 }\end{array}$ & pH 3 & pH 2 & pH 1 \\
\hline $\mathrm{Al}$ & 0.79 & 15 & 16 & 17 \\
\hline $\mathrm{Fe}$ & 0.032 & 4.6 & 5.3 & 6.9 \\
\hline $\mathrm{Gd}$ & 5.8 & 60 & 65 & 81 \\
\hline $\mathrm{Mg}$ & 25 & 36 & 42 & 53 \\
\hline $\mathrm{Mn}$ & 18 & 61 & 68 & 76 \\
\hline $\mathrm{Na}$ & 83 & 104 & 99 & 99 \\
\hline $\mathrm{Ni}$ & 0.86 & 13 & 15 & 18 \\
\hline $\mathrm{S}$ & 69 & 87 & 85 & 83 \\
\hline
\end{tabular}

Table 3-11. Percent Solubility of Select Radionuclides as Measured by ICP-MS

\begin{tabular}{|l|c|c|c|c|}
\hline & $\begin{array}{c}\text { SC-18 SRAT } \\
\text { Product, pH 7 }\end{array}$ & pH 3 & pH 2 & pH 1 \\
\hline $\mathrm{La}(139)$ & 6.7 & 36 & 45 & 49 \\
\hline $\mathrm{Nd}(143-46,148,150)$ & 2.4 & 33 & 40 & 44 \\
\hline $\mathrm{Gd}(155-58,160)$ & 5.8 & 50 & 53 & 62 \\
\hline $\mathrm{U}(235,238)$ & 14 & 101 & 98 & 96 \\
\hline $\mathrm{Pu}(239)$ & 0.43 & 22 & 26 & 30 \\
\hline $\mathrm{Np}(237)$ & 20 & 74 & 76 & 77 \\
\hline
\end{tabular}

The TTR governing this work requested that all replicates of certain elemental components $(\mathrm{Fe}, \mathrm{Gd}, \mathrm{Mn}$, and $\mathrm{Th}$ ) be reported for the $\mathrm{pH}$ adjusted SRAT products. ${ }^{3}$ It was also requested that all replicates be reported for uranium and plutonium isotopes, Am-242m, Cm-244, and Cm-245. ${ }^{3}$ Appendix A contains data from the individual results for the requested constituents for the SRAT product slurries (Table A-1 through Table A-6) and SRAT product filtrates (Table A-7 through Table A-12). Comparisons of the averaged results of the slurries and filtrates are reported in Table 3-12 and Table 3-13, respectively. Results measured by ICP-AES and ICP-MS are presented with units of $\mathrm{mg} / \mathrm{kg}$ of slurry for slurry samples and $\mathrm{mg} / \mathrm{L}$ of filtrate for filtrate samples. Results measured by radiochemical analyses are presented with units of $\mathrm{dpm} / \mathrm{g}$ of slurry for slurry samples and $\mathrm{dpm} / \mathrm{mL}$ of filtrate for filtrate samples. Counting uncertainties are provided with the radiochemical analysis as a major constituent of the overall analysis uncertainty. High counting uncertainties are encountered when isotopes are at low concentrations approaching the detectable level for the method performed. 
Table 3-12. Comparison of pH Adjusted Slurry Analysis Results ${ }^{i}$

\begin{tabular}{|c|c|c|c|c|c|c|c|}
\hline \multirow{2}{*}{$\begin{array}{c}\text { Constituent } \\
\text { (mg/kg slurry) }\end{array}$} & \multirow{2}{*}{ Method } & \multicolumn{2}{|c|}{ pH 3 Slurry } & \multicolumn{2}{|c|}{ pH 2 Slurry } & \multicolumn{2}{|c|}{ pH 1 Slurry } \\
\hline & & Result & $\%$ RSD & Result & $\%$ RSD & Result & $\%$ RSD \\
\hline Fe by AR & ICP-AES & $2.05 \mathrm{E}+04$ & 12 & $1.78 \mathrm{E}+04$ & 16 & $1.87 \mathrm{E}+04$ & 5.0 \\
\hline Fe by PF & ICP-AES & $2.92 \mathrm{E}+04$ & 1.0 & $2.75 \mathrm{E}+04$ & 0.7 & $2.67 \mathrm{E}+04$ & 1.1 \\
\hline Gd by AR & ICP-AES & $1.32 \mathrm{E}+02$ & 11 & $1.26 \mathrm{E}+02$ & 11 & $1.27 \mathrm{E}+02$ & 3.4 \\
\hline Gd by PF & ICP-AES & $1.28 \mathrm{E}+02$ & 2.7 & $1.15 \mathrm{E}+02$ & 5.9 & $1.06 \mathrm{E}+02$ & 5.0 \\
\hline Mn by AR & ICP-AES & $8.86 \mathrm{E}+03$ & 9.6 & $8.37 \mathrm{E}+03$ & 11 & $8.19 \mathrm{E}+03$ & 4.0 \\
\hline Mn by PF & ICP-AES & $9.30 \mathrm{E}+03$ & 1.1 & $8.65 \mathrm{E}+03$ & 1.0 & $8.39 \mathrm{E}+03$ & 0.8 \\
\hline Th by AR & ICP-AES & $1.15 \mathrm{E}+03$ & 12 & $1.00 \mathrm{E}+03$ & 15 & $1.05 \mathrm{E}+03$ & 5.1 \\
\hline Th by PF & ICP-AES & $1.62 \mathrm{E}+03$ & 2.7 & $1.45 \mathrm{E}+03$ & 5.6 & $1.47 \mathrm{E}+03$ & 1.7 \\
\hline $\mathrm{U}$ by $\mathrm{AR}$ & ICP-AES & $5.32 \mathrm{E}+03$ & 9.9 & $5.06 \mathrm{E}+03$ & 10 & $4.90 \mathrm{E}+03$ & 4.1 \\
\hline $\mathrm{U}$ by $\mathrm{PF}$ & ICP-AES & $6.00 \mathrm{E}+03$ & 1.4 & $5.40 \mathrm{E}+03$ & 2.8 & $5.23 \mathrm{E}+03$ & 0.6 \\
\hline Th-232 & ICP-MS & $1.01 \mathrm{E}+03$ & 13 & $8.66 \mathrm{E}+02$ & 15 & $9.21 \mathrm{E}+02$ & 5.6 \\
\hline U-233 & ICP-MS & $1.00 \mathrm{E}+00$ & 10 & $9.23 \mathrm{E}-01$ & 11 & $9.07 \mathrm{E}-01$ & 3.5 \\
\hline U-234 & ICP-MS & $1.23 \mathrm{E}+00$ & 10 & $1.15 \mathrm{E}+00$ & 11 & $1.13 \mathrm{E}+00$ & 4.3 \\
\hline U-235 & ICP-MS & $5.78 \mathrm{E}+01$ & 17 & $5.10 \mathrm{E}+01$ & 10 & $4.96 \mathrm{E}+01$ & 4.6 \\
\hline U-236 & ICP-MS & $2.85 \mathrm{E}+00$ & 9.0 & $2.68 \mathrm{E}+00$ & 11 & $2.64 \mathrm{E}+00$ & 3.9 \\
\hline U-238 & ICP-MS & $5.52 \mathrm{E}+03$ & 10 & $5.19 \mathrm{E}+03$ & 10 & $5.04 \mathrm{E}+03$ & 4.7 \\
\hline $\mathrm{Pu}-239$ & ICP-MS & $1.19 \mathrm{E}+01$ & 10 & $1.05 \mathrm{E}+01$ & 12 & $1.10 \mathrm{E}+01$ & 5.8 \\
\hline $\mathrm{Pu}-240$ & ICP-MS & $1.12 \mathrm{E}+00$ & 11 & $9.75 \mathrm{E}-01$ & 12 & $1.02 \mathrm{E}+00$ & 6.2 \\
\hline Mass 241 & ICP-MS & 7.11E-01 & 12 & $6.34 \mathrm{E}-01$ & 14 & $6.52 \mathrm{E}-01$ & 4.9 \\
\hline Mass 242 & ICP-MS & $<1.70 \mathrm{E}-01$ & NA & $<1.85 \mathrm{E}-01$ & NA & $<1.75 \mathrm{E}-01$ & NA \\
\hline Mass 243 & ICP-MS & $<1.70 \mathrm{E}-01$ & NA & $<1.85 \mathrm{E}-01$ & NA & $<1.75 \mathrm{E}-01$ & NA \\
\hline Mass 244 & ICP-MS & $<8.48 \mathrm{E}-02$ & NA & $<9.25 \mathrm{E}-02$ & NA & $<8.75 \mathrm{E}-02$ & NA \\
\hline
\end{tabular}

${ }^{\mathrm{i}}$ ICP-MS data were generated from AR digested slurry. 
Table 3-13. Comparison of pH Adjusted Slurry Filtrate Analysis Results

\begin{tabular}{|c|c|c|c|c|c|c|c||}
\hline \multirow{2}{*}{$\begin{array}{c}\text { Constituent } \\
\text { (mg/kg filtrate) }\end{array}$} & \multirow{2}{*}{ Method } & \multicolumn{2}{|c|}{ pH 3 Filtrate } & \multicolumn{2}{c|}{ pH 2 Filtrate } & \multicolumn{2}{c||}{ pH 1 Filtrate } \\
\cline { 3 - 8 } & & Result & \%RSD & Result & \%RSD & Result & \%RSD \\
\hline Fe & ICP-AES & $1.48 \mathrm{E}+03$ & 11 & $1.67 \mathrm{E}+03$ & 4.9 & $2.11 \mathrm{E}+03$ & 1.0 \\
\hline $\mathrm{Gd}$ & ICP-AES & $8.54 \mathrm{E}+01$ & 4.0 & $8.49 \mathrm{E}+01$ & 1.8 & $9.88 \mathrm{E}+01$ & 1.2 \\
\hline $\mathrm{Mn}$ & ICP-AES & $6.33 \mathrm{E}+03$ & 5.8 & $6.70 \mathrm{E}+03$ & 2.0 & $7.34 \mathrm{E}+03$ & 0.7 \\
\hline $\mathrm{Th}$ & ICP-AES & $1.65 \mathrm{E}+02$ & 1.6 & $1.57 \mathrm{E}+02$ & 2.0 & $1.65 \mathrm{E}+02$ & 1.3 \\
\hline $\mathrm{U}$ & ICP-AES & $6.17 \mathrm{E}+03$ & 1.8 & $5.73 \mathrm{E}+03$ & 0.7 & $5.56 \mathrm{E}+03$ & 0.8 \\
\hline Th-232 & ICP-MS & $5.19 \mathrm{E}+01$ & 8.2 & $5.33 \mathrm{E}+01$ & 4.8 & $6.32 \mathrm{E}+01$ & 1.3 \\
\hline $\mathrm{U}-233$ & ICP-MS & $9.70 \mathrm{E}-01$ & 2.4 & $8.80 \mathrm{E}-01$ & 0.8 & $8.50 \mathrm{E}-01$ & 1.2 \\
\hline $\mathrm{U}-234$ & ICP-MS & $1.24 \mathrm{E}+00$ & 3.4 & $1.16 \mathrm{E}+00$ & 1.3 & $1.13 \mathrm{E}+00$ & 1.8 \\
\hline $\mathrm{U}-235$ & ICP-MS & $5.95 \mathrm{E}+01$ & 2.5 & $5.52 \mathrm{E}+01$ & 0.4 & $5.30 \mathrm{E}+01$ & 0.5 \\
\hline $\mathrm{U}-236$ & ICP-MS & $3.48 \mathrm{E}+00$ & 2.6 & $3.18 \mathrm{E}+00$ & 0.9 & $3.07 \mathrm{E}+00$ & 1.1 \\
\hline $\mathrm{U}-238$ & ICP-MS & $6.24 \mathrm{E}+03$ & 2.6 & $5.80 \mathrm{E}+03$ & 0.5 & $5.57 \mathrm{E}+03$ & 0.4 \\
\hline $\mathrm{Pu}-239$ & ICP-MS & $2.96 \mathrm{E}+00$ & 6.5 & $3.12 \mathrm{E}+00$ & 3.1 & $3.77 \mathrm{E}+00$ & 1.4 \\
\hline $\mathrm{Pu}-240$ & ICP-MS & $2.22 \mathrm{E}-01$ & 6.1 & $2.36 \mathrm{E}-01$ & 3.0 & $2.88 \mathrm{E}-01$ & 2.7 \\
\hline
\end{tabular}

Table 3-14 and Table 3-15 report the analyzed anion concentrations of the $\mathrm{pH}$ adjusted SRAT product supernatant and slurry by water diluted preparations. Table 3-16 reports the anion concentrations by CQ preparations. The CQ method was developed for acidic slurries with the intent of improving the glycolic analytical results. ${ }^{14}$ As seen in the tables, nitrate concentration increases as $\mathrm{pH}$ decreases, which is consistent with the increasing additions of nitric acid. Generally, all other constituents decrease as $\mathrm{pH}$ decreases. Good data agreement exists between the two analytical methods for most constituents. Similar to what was previously reported, ${ }^{2,14}$ oxalate and formate values resulting from the CQ method are larger than those resulting from the water dilution method. The CQ method remains the recommended method for more accurate organics analysis in slurries, even at lower slurry $\mathrm{pH}$. 
Table 3-14. Water Diluted Anions in the Supernatant $(n=4)$

\begin{tabular}{|c|c|c|c|c|c|c||}
\hline \multirow{2}{*}{$\begin{array}{c}\text { Constituent } \\
\text { (mg/kg supernatant) }\end{array}$} & \multicolumn{2}{|c|}{ pH 3 } & \multicolumn{2}{c|}{ pH 2 } & \multicolumn{2}{c||}{ pH 1 } \\
\cline { 2 - 7 } & Concentration & \%RSD & Concentration & \%RSD & Concentration & \%RSD \\
\hline Fluoride & $<8.26 \mathrm{E}+02$ & NA & $<7.99 \mathrm{E}+02$ & NA & $<8.08 \mathrm{E}+02$ & NA \\
\hline Formate & $2.22 \mathrm{E}+03$ & 4.0 & $2.16 \mathrm{E}+03$ & 2.1 & $2.15 \mathrm{E}+03$ & 3.4 \\
\hline Chloride & $<8.26 \mathrm{E}+02$ & NA & $<7.99 \mathrm{E}+02$ & NA & $<8.08 \mathrm{E}+02$ & NA \\
\hline Nitrite & $<8.26 \mathrm{E}+02$ & NA & $<7.99 \mathrm{E}+02$ & NA & $<8.08 \mathrm{E}+02$ & NA \\
\hline Nitrate & $6.36 \mathrm{E}+04$ & 3.3 & $9.02 \mathrm{E}+04$ & 0.90 & $1.02 \mathrm{E}+05$ & 1.3 \\
\hline Phosphate & $<8.26 \mathrm{E}+02$ & NA & $<7.99 \mathrm{E}+02$ & NA & $<8.08 \mathrm{E}+02$ & NA \\
\hline Sulfate & $1.34 \mathrm{E}+03$ & 8.4 & $1.25 \mathrm{E}+03$ & 1.3 & $1.20 \mathrm{E}+03$ & 2.8 \\
\hline Oxalate & $2.86 \mathrm{E}+03$ & 2.0 & $2.73 \mathrm{E}+03$ & 5.7 & $3.08 \mathrm{E}+03$ & 1.6 \\
\hline Bromide & $<8.26 \mathrm{E}+02$ & NA & $<7.99 \mathrm{E}+02$ & NA & $<8.08 \mathrm{E}+02$ & NA \\
\hline Glycolate & $7.94 \mathrm{E}+04$ & 2.8 & $7.84 \mathrm{E}+04$ & 0.84 & $7.60 \mathrm{E}+04$ & 2.0 \\
\hline \hline
\end{tabular}

Table 3-15. Water Diluted Anions in the Slurry $(n=4)$

\begin{tabular}{|c|c|c|c|c|c|c||}
\hline \multirow{2}{*}{$\begin{array}{c}\text { Constituent } \\
\text { (mg/kg slurry) }\end{array}$} & \multicolumn{2}{|c}{ pH 3 } & \multicolumn{2}{c|}{ pH 2 } & \multicolumn{2}{c|}{ pH 1 } \\
\cline { 2 - 7 } & Concentration & \% RSD & Concentration & \%RSD & Concentration & \%RSD \\
\hline Fluoride & $<7.42 \mathrm{E}+02$ & NA & $<7.03 \mathrm{E}+02$ & NA & $<6.99 \mathrm{E}+02$ & NA \\
\hline Formate & $2.00 \mathrm{E}+03$ & 4.0 & $1.90 \mathrm{E}+03$ & 2.1 & $1.86 \mathrm{E}+03$ & 3.4 \\
\hline Chloride & $<7.42 \mathrm{E}+02$ & NA & $<7.03 \mathrm{E}+02$ & NA & $<6.99 \mathrm{E}+02$ & NA \\
\hline Nitrite & $<7.42 \mathrm{E}+02$ & NA & $<7.03 \mathrm{E}+02$ & NA & $<6.99 \mathrm{E}+02$ & NA \\
\hline Nitrate & $5.71 \mathrm{E}+04$ & 3.3 & $7.93 \mathrm{E}+04$ & 0.9 & $8.84 \mathrm{E}+04$ & 1.3 \\
\hline Phosphate & $<7.42 \mathrm{E}+02$ & NA & $<7.03 \mathrm{E}+02$ & NA & $<6.99 \mathrm{E}+02$ & NA \\
\hline Sulfate & $1.20 \mathrm{E}+03$ & 8.4 & $1.10 \mathrm{E}+03$ & 1.3 & $1.03 \mathrm{E}+03$ & 2.8 \\
\hline Oxalate & $2.57 \mathrm{E}+03$ & 2.0 & $2.40 \mathrm{E}+03$ & 5.7 & $2.66 \mathrm{E}+03$ & 1.6 \\
\hline Bromide & $<7.42 \mathrm{E}+02$ & NA & $<7.03 \mathrm{E}+02$ & NA & $<6.99 \mathrm{E}+02$ & NA \\
\hline Glycolate & $7.13 \mathrm{E}+04$ & 2.8 & $6.90 \mathrm{E}+04$ & 0.8 & $6.57 \mathrm{E}+04$ & 2.0 \\
\hline
\end{tabular}


Table 3-16. Caustic Quenched Anions in the Slurry $(n=2)$

\begin{tabular}{|c|c|c|c|c|c|c||}
\hline \multirow{2}{*}{$\begin{array}{c}\text { Constituent } \\
\text { (mg/kg slurry }\end{array}$} & \multicolumn{2}{|c}{ pH 3 } & \multicolumn{2}{c|}{ pH 2 } & \multicolumn{2}{c|}{ pH 1 } \\
\cline { 2 - 7 } & Concentration & \%RSD & Concentration & \%RSD & Concentration & \%RSD \\
\hline Fluoride & $<5.90 \mathrm{E}+02$ & NA & $<5.90 \mathrm{E}+02$ & NA & $<5.56 \mathrm{E}+02$ & NA \\
\hline Formate & $2.63 \mathrm{E}+03$ & 0.3 & $2.50 \mathrm{E}+03$ & 0.5 & $2.40 \mathrm{E}+03$ & 0.9 \\
\hline Chloride & $<5.90 \mathrm{E}+02$ & NA & $<5.90 \mathrm{E}+02$ & NA & $<5.56 \mathrm{E}+02$ & NA \\
\hline Nitrite & $<5.90 \mathrm{E}+02$ & NA & $<5.90 \mathrm{E}+02$ & NA & $<5.56 \mathrm{E}+02$ & NA \\
\hline Nitrate & $5.65 \mathrm{E}+04$ & 1.2 & $7.77 \mathrm{E}+04$ & 0.8 & $8.96 \mathrm{E}+04$ & 0.2 \\
\hline Phosphate & $<5.90 \mathrm{E}+02$ & NA & $<5.90 \mathrm{E}+02$ & NA & $<5.56 \mathrm{E}+02$ & NA \\
\hline Sulfate & $1.15 \mathrm{E}+03$ & 0.3 & $1.08 \mathrm{E}+03$ & 0.3 & $1.04 \mathrm{E}+03$ & 0.3 \\
\hline Oxalate & $3.87 \mathrm{E}+03$ & 0.6 & $3.58 \mathrm{E}+03$ & 8.2 & $3.53 \mathrm{E}+03$ & 0.6 \\
\hline Bromide & $<5.90 \mathrm{E}+02$ & NA & $<5.90 \mathrm{E}+02$ & NA & $<5.56 \mathrm{E}+02$ & NA \\
\hline Glycolate & $6.98 \mathrm{E}+04$ & 0.8 & $6.85 \mathrm{E}+04$ & 1.0 & $6.71 \mathrm{E}+04$ & 0.5 \\
\hline \hline
\end{tabular}

The mass ratio of iron to $\mathrm{Pu}-239$ on both a slurry and filtrate basis, as measured by ICP-MS analysis of the AR digested slurries, is presented in Table 3-17. The ratio has been determined using the Pu-239 isotope from ICP-MS and not a calculated equivalent $\mathrm{Pu}-239$ as needed for the Nuclear Criticality Safety Evaluation. ${ }^{15}$ Based on the plutonium isotopics in the feed, the Pu-239 measurements would need to be multiplied by a factor of 1.20 to represent total plutonium. 
Table 3-17. Concentrations and Ratios of Select Components of the AR Digested Slurries

\begin{tabular}{|l|c|c|c|c||}
\hline & $\begin{array}{c}\text { SC-18 SRAT } \\
\text { Product, pH 7 }\end{array}$ & pH 3 & pH 2 & pH 1 \\
\hline Slurry Iron, mg/kg & $3.46 \mathrm{E}+04$ & $2.05 \mathrm{E}+04$ & $1.78 \mathrm{E}+04$ & $1.87 \mathrm{E}+04$ \\
\hline Filtrate Iron, $\mathrm{mg} / \mathrm{kg}$ & $1.10 \mathrm{E}+01$ & $1.48 \mathrm{E}+03$ & $1.67 \mathrm{E}+03$ & $2.11 \mathrm{E}+03$ \\
\hline Slurry $\mathrm{Mn}, \mathrm{mg} / \mathrm{kg}$ & $1.15 \mathrm{E}+04$ & $8.86 \mathrm{E}+03$ & $8.37 \mathrm{E}+03$ & $8.19 \mathrm{E}+03$ \\
\hline Slurry $\mathrm{Pu}-239, \mathrm{mg} / \mathrm{kg}$ & $1.89 \mathrm{E}+01$ & $1.19 \mathrm{E}+01$ & $1.05 \mathrm{E}+01$ & $1.10 \mathrm{E}+01$ \\
\hline Filtrate $\mathrm{Pu}-239, \mathrm{mg} / \mathrm{kg}$ & $8.00 \mathrm{E}-02$ & $2.96 \mathrm{E}+00$ & $3.11 \mathrm{E}+00$ & $3.77 \mathrm{E}+00$ \\
\hline Fe:Pu-239 slurry & $1.83 \mathrm{E}+03$ & $1.73 \mathrm{E}+03$ & $1.70 \mathrm{E}+03$ & $1.71 \mathrm{E}+03$ \\
\hline Fe:Pu-239 filtrate & $1.36 \mathrm{E}+02$ & $5.00 \mathrm{E}+02$ & $5.35 \mathrm{E}+02$ & $5.60 \mathrm{E}+02$ \\
\hline $\mathrm{Mn}: \mathrm{Pu}-239$ slurry & $6.08 \mathrm{E}+02$ & $7.48 \mathrm{E}+02$ & $8.00 \mathrm{E}+02$ & $7.48 \mathrm{E}+02$ \\
\hline $239 \mathrm{Pu}(\mathrm{NO})_{4}$ g/L filtrate basis ${ }^{\mathrm{ii}}$ & $1.85 \mathrm{E}-04$ & $6.75 \mathrm{E}-03$ & $7.11 \mathrm{E}-03$ & $8.60 \mathrm{E}-03$ \\
\hline
\end{tabular}

Given that the results of the ICP-MS analyzed AR digested slurries were lower than expected, the mass ratio of iron to $\mathrm{Pu}-239$ on both a slurry and filtrate basis, as measured by ICP-MS analysis of the PF digested slurries, is presented in Table 3-18.

Table 3-18. Concentrations and Ratios of Select Components of the PF Digested Slurries

\begin{tabular}{|l|c|c|c|c||}
\hline & $\begin{array}{c}\text { SC-18 SRAT } \\
\text { Product, pH 7 }\end{array}$ & pH 3 & pH 2 & pH 1 \\
\hline Slurry Iron, mg/kg & $3.46 \mathrm{E}+04$ & $2.92 \mathrm{E}+04$ & $2.75 \mathrm{E}+04$ & $2.67 \mathrm{E}+04$ \\
\hline Filtrate Iron, $\mathrm{mg} / \mathrm{kg}$ & $1.10 \mathrm{E}+01$ & $1.48 \mathrm{E}+03$ & $1.67 \mathrm{E}+03$ & $2.11 \mathrm{E}+03$ \\
\hline Slurry $\mathrm{Mn}, \mathrm{mg} / \mathrm{kg}$ & $1.15 \mathrm{E}+04$ & $9.30 \mathrm{E}+03$ & $8.65 \mathrm{E}+03$ & $8.39 \mathrm{E}+03$ \\
\hline Slurry $\mathrm{Pu}-239, \mathrm{mg} / \mathrm{kg}$ & $1.89 \mathrm{E}+01$ & $1.94 \mathrm{E}+01$ & $1.68 \mathrm{E}+01$ & $1.64 \mathrm{E}+01$ \\
\hline Filtrate $\mathrm{Pu}-239, \mathrm{mg} / \mathrm{kg}$ & $8.00 \mathrm{E}-02$ & $2.96 \mathrm{E}+00$ & $3.11 \mathrm{E}+00$ & $3.77 \mathrm{E}+00$ \\
\hline Fe:Pu-239 slurry & $1.83 \mathrm{E}+03$ & $1.51 \mathrm{E}+03$ & $1.64 \mathrm{E}+03$ & $1.63 \mathrm{E}+03$ \\
\hline Fe:Pu-239 filtrate & $1.36 \mathrm{E}+02$ & $5.00 \mathrm{E}+02$ & $5.35 \mathrm{E}+02$ & $5.60 \mathrm{E}+02$ \\
\hline $\mathrm{Mn}: \mathrm{Pu}-239$ slurry & $6.08 \mathrm{E}+02$ & $4.80 \mathrm{E}+02$ & $5.16 \mathrm{E}+02$ & $5.12 \mathrm{E}+02$ \\
\hline${ }^{239} \mathrm{Pu}\left(\mathrm{NO}_{3}\right)_{4} \mathrm{~g} / \mathrm{L}$ filtrate basis ${ }^{\mathrm{ii}}$ & $1.85 \mathrm{E}-04$ & $6.75 \mathrm{E}-03$ & $7.11 \mathrm{E}-03$ & $8.60 \mathrm{E}-03$ \\
\hline \hline
\end{tabular}

\footnotetext{
ii The supernatant densities of the $\mathrm{pH} \mathrm{3,2,} \mathrm{and} 1$ samples were not measured. The density value used to convert the Pu-239 from a $\mathrm{mg} / \mathrm{kg}$ supernatant basis to a $\mathrm{g} / \mathrm{L}$ supernatant basis was calculated by taking the difference between the $\mathrm{pH} 6$ and $\mathrm{pH} 1$ supernatant densities of the 2011 demonstration and adding that difference to the SC-18 SRAT product supernatant density value. This results in a value of $1.12 \mathrm{~g} / \mathrm{mL}$. This density value was used for all three $\mathrm{pH}$ samples.
} 
The minimum Fe:Pu-239(eq) ratio allowed by the DWPF Waste Acceptance Criteria (WAC) is $\geq 160: 1$. $^{16}$ The lowest Fe:Pu-239 slurry ratio observed during this testing was $1.70 \mathrm{E}+03$ at $\mathrm{pH} 1$ for the AR digested slurries and $1.51 \mathrm{E}+03$ for the PF digested slurries. Also reported is the ${ }^{239} \mathrm{Pu}\left(\mathrm{NO}_{3}\right)_{4}$ concentration in the supernate. This concentration is far lower than the $7.3 \mathrm{~g} / \mathrm{L}$ limit specified by the ANS regulation for nuclear criticality safety in operations with fissionable material outside reactors. ${ }^{17}$ Other ratios important to criticality are also summarized in Table 3-17 and Table 3-18.

Since radionuclides and iron are not being removed from or added to the slurry during testing, the ratios in the slurry were constant as expected. When considering only the insoluble solids, the Fe:Pu-239 ratios slightly increase as reported in Table 3-19. This increase results from iron having smaller change in percent solubility than plutonium as $\mathrm{pH}$ decreases.

Table 3-19. Iron to Pu-239 Ratios and Concentrations on an Insoluble Solids Basis

\begin{tabular}{||l|c|c|c||}
\hline & pH 3 & pH 2 & pH 1 \\
\hline Iron by $\mathrm{AR}, \mathrm{mg} / \mathrm{kg}$ & $1.92 \mathrm{E}+04$ & $1.63 \mathrm{E}+04$ & $1.68 \mathrm{E}+04$ \\
\hline Iron by $\mathrm{PF}, \mathrm{mg} / \mathrm{kg}$ & $2.79 \mathrm{E}+04$ & $2.61 \mathrm{E}+04$ & $2.48 \mathrm{E}+04$ \\
\hline $\mathrm{Pu}-239$ by $\mathrm{AR}, \mathrm{mg} / \mathrm{kg}$ & $9.19 \mathrm{E}+00$ & $7.72 \mathrm{E}+00$ & $7.69 \mathrm{E}+00$ \\
\hline $\mathrm{Pu}-239$ by $\mathrm{PF}, \mathrm{mg} / \mathrm{kg}$ & $1.67 \mathrm{E}+01$ & $1.40 \mathrm{E}+01$ & $1.31 \mathrm{E}+01$ \\
\hline $\mathrm{Fe}: \mathrm{Pu}-239$ by AR & $2.09 \mathrm{E}+03$ & $2.12 \mathrm{E}+03$ & $2.19 \mathrm{E}+03$ \\
\hline $\mathrm{Fe}: \mathrm{Pu}-239$ by $\mathrm{PF}$ & $1.67 \mathrm{E}+03$ & $1.86 \mathrm{E}+03$ & $1.89 \mathrm{E}+03$ \\
\hline
\end{tabular}

For comparison to the previous glycolic-formic flowsheet demonstration, ${ }^{18}$ relevant data are presented in Table 3-20.

Table 3-20. Concentrations and Ratios of Select Components from Previous Glycolic-Formic Demonstration

\begin{tabular}{|l|c|c|c|c||}
\hline & $\begin{array}{c}\text { SC-13 SRAT } \\
\text { Product, pH 6 }\end{array}$ & pH 3 & pH 2 & pH 1 \\
\hline Slurry Iron, $\mathrm{mg} / \mathrm{kg}$ & $2.81 \mathrm{E}+04$ & $2.66 \mathrm{E}+04$ & $2.52 \mathrm{E}+04$ & $2.50 \mathrm{E}+04$ \\
\hline Filtrate Iron, $\mathrm{mg} / \mathrm{kg}$ & $1.69 \mathrm{E}+02$ & $4.15 \mathrm{E}+02$ & $5.51 \mathrm{E}+02$ & $5.55 \mathrm{E}+02$ \\
\hline Slurry $\mathrm{Mn}, \mathrm{mg} / \mathrm{kg}$ & $6.64 \mathrm{E}+03$ & $6.36 \mathrm{E}+03$ & $6.14 \mathrm{E}+03$ & $5.89 \mathrm{E}+03$ \\
\hline Slurry $\mathrm{Pu}-239, \mathrm{mg} / \mathrm{kg}$ & $6.09 \mathrm{E}+01$ & $5.93 \mathrm{E}+01$ & $6.26 \mathrm{E}+01$ & $6.53 \mathrm{E}+01$ \\
\hline Filtrate $\mathrm{Pu}-239, \mathrm{mg} / \mathrm{kg}$ & $1.51 \mathrm{E}+01$ & $1.85 \mathrm{E}+01$ & $1.64 \mathrm{E}+01$ & $6.79 \mathrm{E}+00$ \\
\hline Fe:Pu-239 slurry & $4.62 \mathrm{E}+02$ & $4.49 \mathrm{E}+02$ & $4.02 \mathrm{E}+02$ & $3.83 \mathrm{E}+02$ \\
\hline Fe:Pu-239 filtrate & $1.12 \mathrm{E}+01$ & $2.24 \mathrm{E}+01$ & $3.36 \mathrm{E}+01$ & $8.18 \mathrm{E}+01$ \\
\hline $\mathrm{Mn}: \mathrm{Pu}-239$ slurry & $1.09 \mathrm{E}+02$ & $1.07 \mathrm{E}+02$ & $9.80 \mathrm{E}+01$ & $9.03 \mathrm{E}+01$ \\
\hline${ }^{239} \mathrm{Pu}\left(\mathrm{NO}_{3}\right)_{4} \mathrm{~g} / \mathrm{L}$ filtrate basis & $1.22 \mathrm{E}-02$ & $4.32 \mathrm{E}-02$ & $4.93 \mathrm{E}-02$ & $3.27 \mathrm{E}-02$ \\
\hline
\end{tabular}




\subsection{Product Consistency Test}

Based on the measured masses of the PCT vessels before and after the 7-day test, there was negligible water loss, which was within the bounds allowed by the ASTM procedure. The measured elemental concentrations in the blanks were reported as less than detectable and thus confirmed to be insignificant (less than $10 \%$ of the concentration of the respective element in the sample leachates). The leachate concentrations of $\mathrm{B}, \mathrm{Li}, \mathrm{Na}$, and $\mathrm{Si}$ for the ARM reference glass were within the Thermodynamic Hydration Energy Model (THERMO) control chart limits ${ }^{8}$, which demonstrates that the test was completed under control. Table 3-21 provides a comparison of the triplicate measured multi-element standard solution average results to the reference values. The nominal range of acceptability for comparing the ICP-AES results to the reference values is typically $\pm 10 \%$.

Table 3-21. Multi-Element Standard Solution Results (SM-744-013)

\begin{tabular}{|c|c|c|c||}
\hline \hline Element & $\begin{array}{c}\text { Reference Value } \\
(\mathbf{m g} / \mathbf{L})\end{array}$ & $\begin{array}{c}\text { Measured Value (mg/L) } \\
\text { [St.Dev.] }\end{array}$ & \% Difference \\
\hline $\mathrm{Al}$ & 4 & $4.20[0.01]$ & 5.1 \\
\hline $\mathrm{B}$ & 20 & $20.10[0.10]$ & 0.5 \\
\hline $\mathrm{Fe}$ & 4 & $4.19[0.01]$ & 4.7 \\
\hline $\mathrm{K}$ & 10 & $9.66[0.06]$ & -3.4 \\
\hline $\mathrm{Li}$ & 10 & $10.13[0.12]$ & 1.3 \\
\hline $\mathrm{Na}$ & 81 & $84.47[0.45]$ & 4.3 \\
\hline $\mathrm{Si}$ & 50 & $51.00[0.10]$ & 2.0 \\
\hline
\end{tabular}

Results from the PCT are shown in Table 3-22 including the standard deviations and \%RSD values. Normalized concentrations $\left(N C_{i}\right.$ in units of $\mathrm{g}$ wasteform $/ \mathrm{L}$ leachant for element " $i$ ") of the SB9 SC-18 Qualification Glass were calculated based on the measured glass composition ${ }^{2}$ using the average of the common logarithms of the leachate concentrations. Similar $\mathrm{NC}_{\mathrm{i}}$ calculations were performed on the ARM and EA glass based on their measured glass composition. ${ }^{8,9}$ As discussed in a previous report related to the PCT performed on SC-17 Qualification Glass, no adjustment for the density of glasses was necessary in normalizing the PCT results from this study. ${ }^{19}$

The average normalized concentrations of B, Li, and Na for the SB9 SC-18 Qualification Glass are more than an order of magnitude lower than the corresponding values for the EA glass, which satisfies the acceptability criterion stated in Section 1.3 of the WAPS. ${ }^{6}$ The WAPS states that the normalized releases of $\mathrm{B}, \mathrm{Li}$, and $\mathrm{Na}$ must be at least two standard deviations below the reported releases for these elements in the EA glass. Although not specifically listed in the WAPS, the $N C_{S i}$ values for the SB9 SC-18 Qualification Glass and EA glass are also shown for comparison. The $N C_{U}$ value shown for the SB9 SC18 Qualification Glass gives indication that release of radioactive uranium is bounded by the boron release. 
Table 3-22. $\mathrm{NC}_{i}$ Results Using the Average of the Common Logarithms of the Leachate Concentrations for ARM, EA and the SB9 SC-18 Qualification Glass

\begin{tabular}{|c|c|c|c|c|c|c|}
\hline Glass ID & $\begin{array}{c}N C_{B}(\mathrm{~g} / \mathrm{L}) \\
\text { Std. Dev. } \\
\% \text { RSD }\end{array}$ & $\begin{array}{c}N C_{L i}(\mathrm{~g} / \mathrm{L}) \\
\text { Std. Dev. } \\
\text { \% RSD }\end{array}$ & $\begin{array}{c}N C_{N a}(\mathrm{~g} / \mathrm{L}) \\
\text { Std. Dev. } \\
\% \text { RSD }\end{array}$ & $\begin{array}{c}N C_{S i}(\mathrm{~g} / \mathrm{L}) \\
\text { Std. Dev. } \\
\% \text { RSD }\end{array}$ & $\begin{array}{c}N C_{U}(\mathrm{~g} / \mathrm{L}) \\
\text { Std. Dev. } \\
\% \text { RSD }\end{array}$ & pH \\
\hline $\mathrm{ARM}^{\mathrm{a}}$ & $\begin{array}{c}0.50 \\
0.09 \\
3.3\end{array}$ & $\begin{array}{c}0.59 \\
0.06 \\
2.5\end{array}$ & $\begin{array}{c}0.53 \\
0.09 \\
4.5\end{array}$ & $\begin{array}{c}0.30 \\
0.02 \\
2.7\end{array}$ & ---- & 10.0 \\
\hline $\mathrm{EA}^{\mathrm{b}}$ & $\begin{array}{c}17.26 \\
0.4 \\
2 \\
\end{array}$ & $\begin{array}{c}9.88 \\
0.2 \\
2\end{array}$ & $\begin{array}{c}13.79 \\
0.2 \\
2\end{array}$ & $\begin{array}{c}4.21 \\
0.1 \\
2\end{array}$ & ---- & 11.6 \\
\hline $\begin{array}{c}\text { SB9 } \\
\text { SC-18 } \\
\text { Qual }^{\text {c }}\end{array}$ & $\begin{array}{c}0.75 \\
0.01 \\
1.1\end{array}$ & $\begin{array}{c}0.85 \\
0.01 \\
0.9\end{array}$ & $\begin{array}{c}0.90 \\
0.03 \\
2.9\end{array}$ & $\begin{array}{c}0.49 \\
0.01 \\
1.5\end{array}$ & $\begin{array}{c}0.29 \\
0.01 \\
1.8\end{array}$ & 10.4 \\
\hline
\end{tabular}

${ }^{\text {a }}$ Normalized concentrations are the average of 3 replicates.

${ }^{\mathrm{b}}$ Normalized concentrations are the average of 3 replicates.

${ }^{\mathrm{c}}$ Normalized concentrations are the average of 4 replicates.

\subsection{PCCS Model Predictions}

The measured SB9 SC-18 Qualification Glass composition ${ }^{2}$ was used to predict specific properties of the glass using the Defense Waste Processing Facility (DWPF) Product Composition Control System (PCCS) models. The results were presented in Reference 2. Figure 3-6 demonstrates that the measured PCT releases of the SB9 SC-18 Qualification Glass are predictable by the PCCS models for durability and acceptable relative to the chemical durability of the EA benchmark glass. The dashed lines represent prediction limits at a 95\% confidence for an individual PCT result and the linear fits are shown as solid lines. 


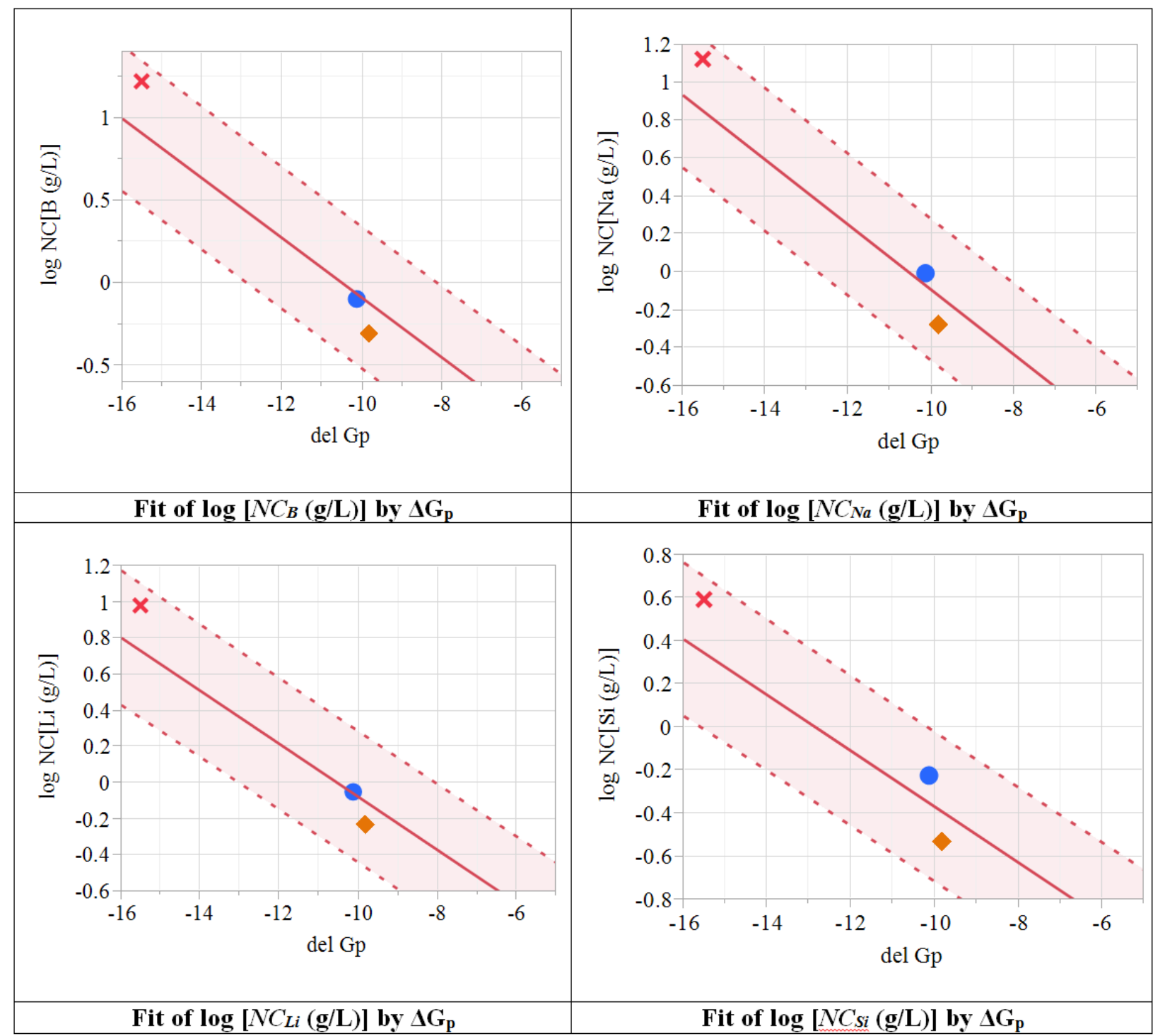

Figure 3-6. $\Delta \mathrm{G}_{\mathrm{p}}$ predictions ( $\mathrm{kcal} / 100 \mathrm{~g}$ glass) versus the log of the normalized concentration $(\mathrm{g} / \mathrm{L})$ for $\mathrm{B}, \mathrm{Li}, \mathrm{Na}$, and $\mathrm{Si}$; $X$ represent published $\mathrm{EA}$ values, ${ }^{8}>$ represent $\mathrm{ARM}$ values and ${ }_{\text {represent }}$ measured SB9 SC-18 Qualification Glass values.

\subsection{REDOX Measurement}

The SC-18 glass prepared by the $\mathrm{CC}_{\text {Hot }}$ method had a measured REDOX that averaged 0.05 with a standard error of 0.01 . The validity of the REDOX measurement is based on the integrity of the crucible seal during vitrification, the homogeneity of the produced glass and the accuracy of the spectrographic measurements on the dissolved samples. Select images of the visual inspection of the crucibles after removal from the furnace and of the glass once separated from the bulk are displayed in Figure 3-7. 
A)

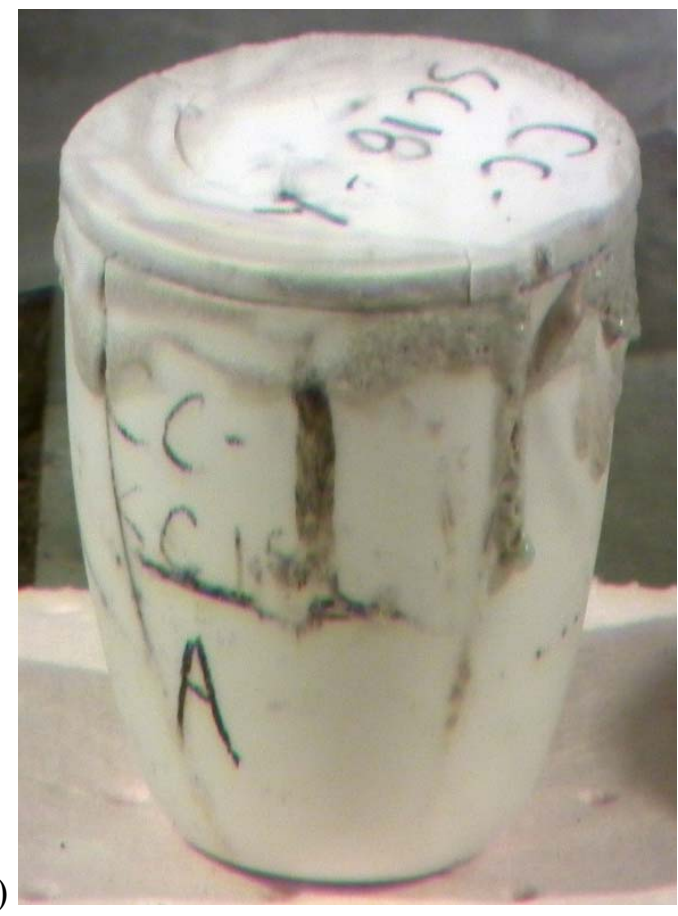

B)

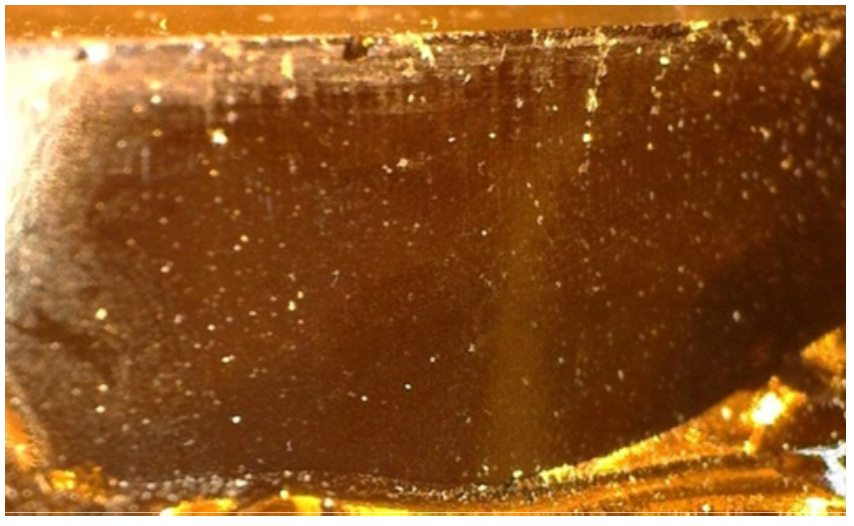

Figure 3-7. A) Image of cooled crucible (note: cracks in the alumina formed upon cooling, not during vitrification); B) Image of extracted glass sample

Visual examination revealed that the crucible integrities were sufficient for two out of the three replicates. The pictured crucible cracking in Figure 3-7A occurred while cooling, not during processing. One crucible had a complete lid failure and the produced glass was deemed unacceptable for measurement. The dark lines on the outside of the crucible are remnants of slurry that got on the outside of the crucible while filling.

The glass quality was also acceptable based on the previous criteria. The specks observed on the surface were debris from separation from the crucible and handling in the Cells. The vertical lines at the top and varying colors at the bottom are due to fracture lines in the glass that reflect light differently and are not indicative of phase inhomogeneity.

Samples of glass were dissolved and analyzed colorimetrically. All measured REDOX ratio values for replicate SC-18 glasses are displayed in Table 3-23 and are labelled as either acceptable or result discarded. 
Table 3-23. REDOX $\left(\mathrm{Fe}^{2+} / \mathrm{\Sigma Fe}\right)$ Measurements in the Cells.

\begin{tabular}{|c|c|c|}
\hline Sample ID & $\begin{array}{c}\text { Measured } \\
\mathrm{Fe}^{2+} / \Sigma \mathrm{Fe} \text { Ratio }\end{array}$ & Acceptability of Results \\
\hline \multicolumn{3}{|l|}{$\mathrm{SC}-18-\mathrm{A}$} \\
\hline Trial 1 & 0.29 & $\begin{array}{l}\text { outlier value; sample likely containing material } \\
\text { not from interior bulk - result discarded }\end{array}$ \\
\hline Trial 2 & 0.04 & acceptable \\
\hline Trial 3 & 0.08 & acceptable \\
\hline \multicolumn{3}{|l|}{ SC-18-B } \\
\hline Trial 1 & $<0.03$ & \multirow{2}{*}{$\begin{array}{l}\text { crucible had lid failure during vitrification, } \\
\text { invalidating REDOX results - results discarded }\end{array}$} \\
\hline Trial 2 & $<0.03$ & \\
\hline \multicolumn{3}{|r|}{ 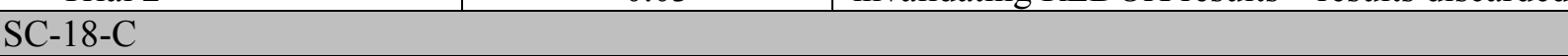 } \\
\hline Trial 1 & 0.04 & acceptable \\
\hline Trial 2 & 0.03 & acceptable \\
\hline Trial 3 & 0.04 & acceptable \\
\hline \multicolumn{3}{|l|}{ Statistics } \\
\hline Mean (of 5 accepted) & 0.046 & \\
\hline Absolute Standard Error & 0.0079 & \\
\hline Percent Standard Error & $17.3 \%$ & \\
\hline
\end{tabular}

Outlier values as a result of possible contamination incorporation or vitrification errors are not accepted as part of the averaged REDOX value. Table 3-24 displays the comparison of the mean measured REDOX value to the predicted REDOX value. The REDOX value was predicted using the analyzed SME product composition and weight percent solids.

Table 3-24. Comparison of Predicted and Measured REDOX Values

\begin{tabular}{||c|c||}
\hline & SC-18 \\
\hline Average Measured REDOX & 0.046 \\
\hline Analyzed SME Predicted REDOX & 0.077 \\
\hline \hline
\end{tabular}

The uncertainty of the analytical measurements of the SME composition plays a role in the disparity of the analyzed SME REDOX prediction as it feeds into the REDOX model equation; typical analytical uncertainty is $\pm 10 \%$ for compositional analyses. More importantly, these measured absorption values are near the detection limit of the Baumann method ( $~ 0.03)$ and result in errors in this range of up to $\pm 100 \%$ for the measured REDOX values. Variability in REDOX measurements between replicate crucibles can also result in a range of measured REDOX values for a single feed. Some additional variability was likely introduced due to the physical limitations of working in the Shielded Cells (i.e. reduced fine motor skills with manipulators to be able to select small pieces of glass and reduced visibility of fine details of glass due to the leaded Cells windows). All of these factors can result in a "noisy" measurement when near the detection limit for the REDOX measurement method, but even with the inclusion of these factors the measured REDOX of the SC-18 replicates is not significantly divergent from the predicted value.

To best represent the goodness of fit for the measured REDOX values, the mean and standard error were calculated utilizing a logarithmic treatment. The log of the measured values was assumed to be normally distributed. When converted back to real values, the logarithmic treatment removes the impossible negative REDOX values and generates a distribution of only positive values. As seen in Figure 3-8, this treatment does eliminate the physically possible value of zero from the distribution, but it provides a more physically meaningful distribution around the measured values observed. 


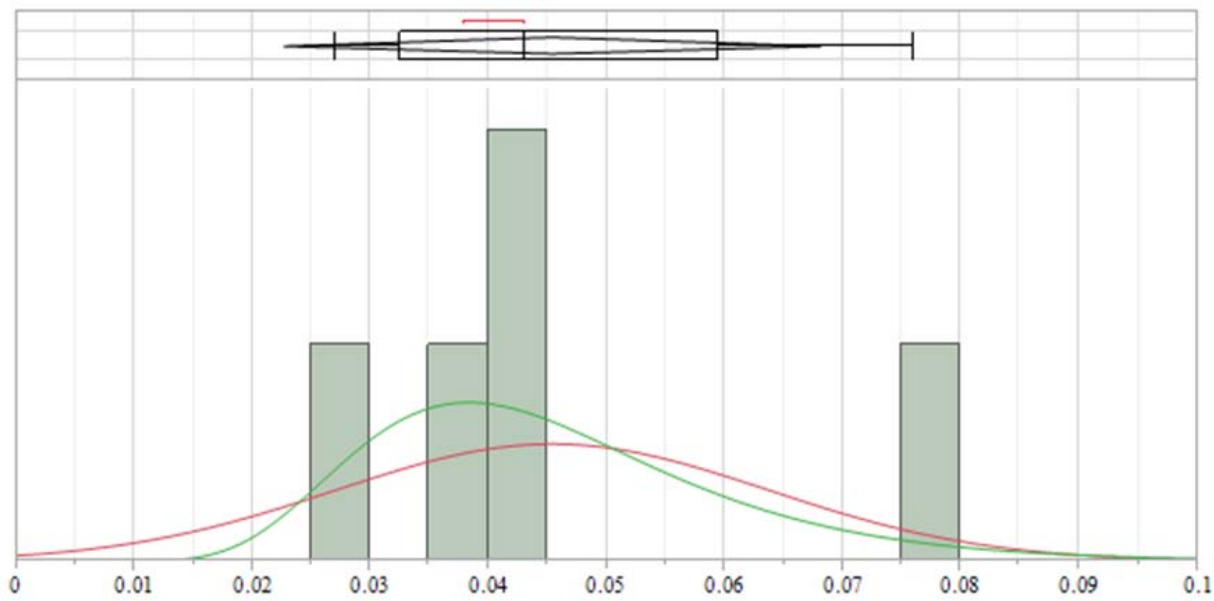

Figure 3-8. Plot of Normal Distribution (red) and Logarithmic-corrected Distribution (green) for the REDOX Replicates.

\subsection{Conclusions}

The following are conclusions from the follow-on testing on the nitric-glycolic flowsheet SB9 qualification run $\mathrm{SC}-18$ :

- In completion of the additional tasks pertaining to the SB9 actual waste qualification for the nitric-glycolic flowsheet, the results obtained did not conflict with the prior conclusions. Based on the current and previous studies, SRNL recommends implementation of the nitric-glycolic acid flowsheet in DWPF

- All results for the volatile organics analysis and semi-volatile organics analysis of the SRAT receipt, SRAT product, and SME product slurries were below the method detection limits $(<6$ to $<16 \mathrm{mg} / \mathrm{L})$.

- In the condensate, the highest soluble mercury concentrations are observed in the early stages of the SRAT cycle (405 $\mathrm{mg} / \mathrm{L}$ at initial heat to boiling).

- TMS, an ADP, was measured in the condensate samples at the end of the SRAT cycle and throughout the SME cycle, ranging from 11 to $62 \mathrm{mg} / \mathrm{L}$ when above the $0.25 \mathrm{mg} / \mathrm{L}$ detection limit. Propanal was quantified just above the $0.25 \mathrm{mg} / \mathrm{L}$ detection limit $(0.27$ and $0.34 \mathrm{mg} / \mathrm{L})$ for two of the nine dewater samples collected during the SME cycle. HMDSO was not measured above the $0.25 \mathrm{mg} / \mathrm{L}$ detection limit.

- From the measurement of mercury from the intermediate and final slurry samples taken during the SC-18 SRAT cycle, mercury stripping appeared to require approximately 1000 grams of conflux (or steam) per gram of mercury stripped.

- Intermediate SRAT slurry samples taken throughout the run showed a gradual removal of nitrite to approximately $2000 \mathrm{mg} / \mathrm{kg}$ in the slurry sample after 13 hours of conflux and $300 \mathrm{mg} / \mathrm{kg}$ in the SRAT product sample after 24 hours of conflux. 
- After adjusting the SC-18 SRAT product to $\mathrm{pH}$ values of 3,2, and 1 with glycolic and nitric acid, the minimum Fe:Pu-239 ratio in the slurry was 1,700 for the AR digested slurries and 1,510 for the PF digested slurries. The minimum $\mathrm{Mn}: \mathrm{Pu}-239$ ratio in the slurry was 748 for the AR digested slurries and 480 for the PF digested slurry. The maximum concentration of soluble $\mathrm{Pu}-239$ was $3.77 \mathrm{mg} / \mathrm{kg}($ at $\mathrm{pH}=1)$.

- Based on the measured composition of the SC-18 Qualification Glass, the product consistency test responses of $\mathrm{B}, \mathrm{Li}$, and $\mathrm{Na}$ are acceptable relative to the chemical durability of the $\mathrm{EA}$ benchmark glass and predictable by current PCCS models for durability.

- Two out of the three crucible samples prepared from SC-18 SME product were deemed acceptable with an accepted measured reduction/oxidation (REDOX: $\mathrm{Fe}^{2+} / \Sigma \mathrm{Fe}$ ) ratio mean of 0.05 with a standard error of 0.01 .

\subsection{Recommendations}

In completion of the additional tasks pertaining to the SB9 actual waste qualification for the nitricglycolic flowsheet, the results obtained did not conflict with the prior conclusions. Based on the current and previous studies, SRNL recommends implementation of the nitric-glycolic acid flowsheet in DWPF

For SB9 with the nitric-glycolic flowsheet, consider running using a higher acid stoichiometry than the $78 \%$ KMA that was used in the SC-18 testing. As recommended elsewhere, ${ }^{10}$ increasing the acid stoichiometry to nearer to $100 \%$ KMA could help in more quickly converting nitrite and should benefit mercury reduction and stripping.

\subsection{Acknowledgements}

The authors acknowledge the support of the shielded cells technicians Monica Jenkins, Nan Stanley, Phyllis Burkhalter, and Jeff Mixon, shielded cells management, and other Environmental and Chemical Processing Technologies Research Program Section researchers Duane Adamson, Wesley Woodham, and Daniel Lambert. Tommy Edwards performed calculations relating to the uncertainty analysis.

\subsection{References}

${ }^{1}$ D. P. Lambert, M. E. Stone, J. D. Newell, D. R. Best and J. R. Zamecnik, "Glycolic-Nitric Acid Flowsheet Demonstration of the DWPF Chemical Process Cell with Sludge and Supernate Simulants", SRNL-STI-2012-00018, Revision 1, August 2012.

2 J. D. Newell, J. M. Pareizs, C. J. Martino, S. H. Reboul, C. J. Coleman, T. B. Edwards and F. C. Johnson, "Actual Waste Demonstration of the Nitric-Glycolic Flowsheet for Sludge Batch 9 Qualification”, SRNL-STI-2016-00327, Revision 1, March 9, 2017.

3 T. L. Fellinger, "Follow on Work to Enhance Knowledge Base for the Nitric-Glycolic Flowsheet", XTTR-S-00041, Revison 0, October 12, 2015. 
${ }^{4}$ D. P. Lambert, C. J. Martino and J. D. Newell, “Task Technical and Quality Assurance Plan for Followon Actual-Waste Work to Enhance Knowledge Base for the Nitric-Glycolic Flowsheet", SRNL-RP2016-00161, Revision 1, October 20, 2016.

5 D. P. Lambert, "Recommendations for Sludge Batch 9 Qualification Processing Under the NitricGlycolic Acid Flowsheet in the Shielded Cells", SRNL-L3100-2016-00077, Revision 0, May 6, 2016.

6 "Waste Acceptance Product Specifications (WAPS) for Vitrified High-Level Waste Forms", DOE/EM0093, Revision 2, 1996.

7 "Standard Test Methods for Determining Chemical Durability of Nuclear, Hazardous, and Mixed Waste Glasses and Multiphase Glass Ceramics: The Product Consistent Test (PCT)", ASTM Method C1285$14,2014$.

${ }^{8}$ C. M. Jantzen, J. B. Pickett, K. G. Brown, T. B. Edwards and D. C. Beam, "Process/Product Models for the Defense Waste Processing Facility (DWPF): Part I. Predicting Glass Durability from Composition Using a Thermodynamic Hydration Energy Reaction Model (THERMO)”, WSRC-TR-93-672, Revision 1, September 28, 1995.

9 C. M. Jantzen, N. E. Bibler, D. C. Beam, C. L. Crawford and M. A. Pickett, "Characterization of the Defense Waste Processing Facility (DWPF) Environmental Assessment (EA) Glass Standard Reference Material”, WSRC-TR-92-346, Revision 1, June 1, 1993.

${ }^{10}$ D. P. Lambert, M. S. Williams, C. H. Brandenburg, M. C. Luther, J. D. Newell and W. H. Woodham, "Sludge Batch 9 Simulant Runs Using the Nitric-Glycolic Acid Flowsheet", SRNL-STI-2016-00319, Revision 0, November 2016.

11 "Heat Treatment of Waste Slurries for REDOX $\left(\mathrm{Fe}^{2+} / \Sigma \mathrm{Fe}\right)$ and Chemical Composition Measurement", Manual L29, Procedure ITS-0052, Revison 5, February 1, 2016.

12 (a) E. W. Baumann, Colorimetric Determination of Iron (II) and Iron (III) in Glass. Analyst 1992, 117, 913-916; (b) "Determining $\mathrm{Fe}^{2+} / \mathrm{Fe}^{3+}$ and $\mathrm{Fe}^{2+} / \mathrm{Fe}$ (Total) Using UV VIS Spectrometer", Manual L29, ITS-0042, Revision 2, August 8, 2014.

${ }^{13}$ D. P. Lambert, J. M. Pareizs and D. R. Click, "Demonstration of the Glycolic-Formic Flowsheet in the SRNL Shileded Cells”, SRNL-STI-2011-00622, Revision 0, November 2011.

${ }^{14}$ T. L. White, D. P. Lambert, J. R. Zamecnik and W. T. Reiley, "Ion Chromatography (IC) Analysis of Glycolate in Simulated Waste", SRNL-STI-2015-00049, Revision 0, May 2015.

${ }^{15}$ H. C. Benhardt, "Nuclar Criticality Safety Evaluation: Processing of Salt Solution Containing High Enrich Uranium and DWPF (U)”, N-NCS-S-00008, Revision 17, August 2016.

16 J. W. Ray, "Waste Acceptance Criteria for Sludge, ARP, and MCU Process Transfers to 512-S and DWPF (U)”, X-SD-G-00008, Revision 22, November 2016.

17 "American National Standard fo Nuclear Criticality Safety in Operations with Fissionable Material Outside Reactors", ANSI-ANS-8.1-1988, 1998.

18 D. P. Lambert and D. C. Koopman, "Glycolic-Formic Acid Flowsheet Sludge Matrix Study”, SRNLSTI-2011-00275, June 30, 2011.

19 J. M. Pareizs, J. D. Newell, C. J. Martino, C. L. Crawford and F. C. Johnson, "Sludge Washing and Demonstration of the DWPF Nitric/Formic Flowsheet in the SRNL Shielded Cells for Sludge Batch 9 Qualification”, SRNL-STI-2016-00355, Revision 0, October 2016. 


\section{Appendix A. Replicate Analyses from Metal Solubility Tests}

Table A-1. Comparison of Replicate pH 3 Slurry Analysis Results

\begin{tabular}{|c|c|c|c|c|c|c|c|}
\hline \multirow{2}{*}{$\begin{array}{l}\text { Constituent } \\
\text { (mg/kg slurry) }\end{array}$} & \multirow{2}{*}{ Method } & \multicolumn{4}{|c|}{ Measured Concentration } & \multirow{2}{*}{ Average } & \multirow{2}{*}{$\%$ RSD } \\
\hline & & Result 1 & Result 2 & Result 3 & Result 4 & & \\
\hline Fe by AR & ICP-AES & $1.90 \mathrm{E}+04$ & $2.16 \mathrm{E}+04$ & $1.79 \mathrm{E}+04$ & $2.35 \mathrm{E}+04$ & $2.05 \mathrm{E}+04$ & 12 \\
\hline Fe by PF & ICP-AES & $2.94 \mathrm{E}+04$ & $2.90 \mathrm{E}+04$ & $2.95 \mathrm{E}+04$ & $2.89 \mathrm{E}+04$ & $2.92 \mathrm{E}+04$ & 1.0 \\
\hline Gd by AR & ICP-AES & $1.36 \mathrm{E}+02$ & $1.37 \mathrm{E}+02$ & $1.12 \mathrm{E}+02$ & $1.44 \mathrm{E}+02$ & $1.25 \mathrm{E}+02$ & 11 \\
\hline Gd by PF & ICP-AES & $1.29 \mathrm{E}+02$ & $1.28 \mathrm{E}+02$ & $1.31 \mathrm{E}+02$ & $1.23 \mathrm{E}+02$ & $1.28 \mathrm{E}+02$ & 2.7 \\
\hline Mn by AR & ICP-AES & $9.24 \mathrm{E}+03$ & $9.14 \mathrm{E}+03$ & $7.60 \mathrm{E}+03$ & $9.46 \mathrm{E}+03$ & $8.86 \mathrm{E}+03$ & 10 \\
\hline Mn by $P F$ & ICP-AES & $9.37 \mathrm{E}+03$ & $9.34 \mathrm{E}+03$ & $9.35 \mathrm{E}+03$ & $9.15 \mathrm{E}+03$ & $9.30 \mathrm{E}+03$ & 1.1 \\
\hline Th by AR & ICP-AES & $1.07 \mathrm{E}+03$ & $1.21 \mathrm{E}+03$ & $9.94 \mathrm{E}+02$ & $1.31 \mathrm{E}+03$ & $1.15 \mathrm{E}+03$ & 12 \\
\hline Th by PF & ICP-AES & $1.58 \mathrm{E}+03$ & $1.58 \mathrm{E}+03$ & $1.66 \mathrm{E}+03$ & $1.65 \mathrm{E}+03$ & $1.62 \mathrm{E}+03$ & 2.7 \\
\hline U by AR & ICP-AES & $5.67 \mathrm{E}+03$ & $5.47 \mathrm{E}+03$ & $4.54 \mathrm{E}+03$ & $5.60 \mathrm{E}+03$ & $5.32 \mathrm{E}+03$ & 10 \\
\hline $\mathrm{U}$ by $\mathrm{PF}$ & ICP-AES & $5.99 \mathrm{E}+03$ & $5.91 \mathrm{E}+03$ & $6.11 \mathrm{E}+03$ & $5.97 \mathrm{E}+03$ & $6.00 \mathrm{E}+03$ & 1.4 \\
\hline Th-232 & ICP-MS & $9.35 \mathrm{E}+02$ & $1.05 \mathrm{E}+03$ & $8.80 \mathrm{E}+02$ & $1.17 \mathrm{E}+03$ & $1.01 \mathrm{E}+03$ & 13 \\
\hline U-233 & ICP-MS & $1.02 \mathrm{E}+00$ & $1.01 \mathrm{E}+00$ & 8.63E-01 & $1.11 \mathrm{E}+00$ & $1.00 \mathrm{E}+00$ & 10 \\
\hline U-234 & ICP-MS & $1.31 \mathrm{E}+00$ & $1.24 \mathrm{E}+00$ & $1.05 \mathrm{E}+00$ & $1.32 \mathrm{E}+00$ & $1.23 \mathrm{E}+00$ & 10 \\
\hline U-235 & ICP-MS & $6.84 \mathrm{E}+01$ & $5.49 \mathrm{E}+01$ & $4.61 \mathrm{E}+01$ & $6.17 \mathrm{E}+01$ & $5.78 \mathrm{E}+01$ & 17 \\
\hline U-236 & ICP-MS & $3.02 \mathrm{E}+00$ & $2.89 \mathrm{E}+00$ & $2.47 \mathrm{E}+00$ & $3.00 \mathrm{E}+00$ & $2.85 \mathrm{E}+00$ & 9.0 \\
\hline U-238 & ICP-MS & $5.91 \mathrm{E}+03$ & $5.64 \mathrm{E}+03$ & $4.71 \mathrm{E}+03$ & $5.83 \mathrm{E}+03$ & $5.52 \mathrm{E}+03$ & 10 \\
\hline Pu-239 & ICP-MS & $1.16 \mathrm{E}+01$ & $1.23 \mathrm{E}+01$ & $1.03 \mathrm{E}+01$ & $1.32 \mathrm{E}+01$ & $1.19 \mathrm{E}+01$ & 10 \\
\hline $\mathrm{Pu}-240$ & ICP-MS & $1.09 \mathrm{E}+00$ & $1.16 \mathrm{E}+00$ & $9.75 \mathrm{E}-01$ & $1.26 \mathrm{E}+00$ & $1.12 \mathrm{E}+00$ & 11 \\
\hline Mass 241 & ICP-MS & $6.87 \mathrm{E}-01$ & 7.36E-01 & $6.10 \mathrm{E}-01$ & $8.09 \mathrm{E}-01$ & $7.11 \mathrm{E}-01$ & 12 \\
\hline Mass 242 & ICP-MS & $<1.67 \mathrm{E}-01$ & $<1.79 \mathrm{E}-01$ & $<1.55 \mathrm{E}-01$ & $<1.78 \mathrm{E}-01$ & $<1.70 \mathrm{E}-01$ & NA \\
\hline Mass 243 & ICP-MS & $<1.67 \mathrm{E}-01$ & $<1.79 \mathrm{E}-01$ & $<1.55 \mathrm{E}-01$ & $<1.78 \mathrm{E}-01$ & $<1.70 \mathrm{E}-01$ & NA \\
\hline Mass 244 & ICP-MS & $<8.34 \mathrm{E}-02$ & $<8.95 \mathrm{E}-02$ & $<7.74 \mathrm{E}-02$ & $<8.90 \mathrm{E}-02$ & $<8.48 \mathrm{E}-02$ & NA \\
\hline
\end{tabular}

$\mathrm{AR} \#=$ aqua regia digestion number; $\mathrm{PF} \#=$ peroxide fusion digestion number. 
Table A-2. Comparison of Replicate pH 2 Slurry Analysis Results

\begin{tabular}{|c|c|c|c|c|c|c|c|}
\hline \multirow{2}{*}{$\begin{array}{l}\text { Constituent } \\
\text { (mg/kg slurry) }\end{array}$} & \multirow{2}{*}{ Method } & \multicolumn{4}{|c|}{ Measured Concentration } & \multirow{2}{*}{ Average } & \multirow{2}{*}{$\%$ RSD } \\
\hline & & Result 1 & Result 2 & Result 3 & Result 4 & & \\
\hline Fe by AR & ICP-AES & $1.76 \mathrm{E}+04$ & $1.66 \mathrm{E}+04$ & $1.52 \mathrm{E}+04$ & $2.18 \mathrm{E}+04$ & $1.78 \mathrm{E}+04$ & 16 \\
\hline Fe by PF & ICP-AES & $2.77 \mathrm{E}+04$ & $2.73 \mathrm{E}+04$ & $2.74 \mathrm{E}+04$ & $2.77 \mathrm{E}+04$ & $2.75 \mathrm{E}+04$ & 0.7 \\
\hline Gd by AR & ICP-AES & $1.31 \mathrm{E}+02$ & $1.26 \mathrm{E}+02$ & $1.07 \mathrm{E}+02$ & $1.40 \mathrm{E}+02$ & $1.26 \mathrm{E}+02$ & 11 \\
\hline Gd by PF & ICP-AES & $1.22 \mathrm{E}+02$ & $1.11 \mathrm{E}+02$ & $1.20 \mathrm{E}+02$ & $1.08 \mathrm{E}+02$ & $1.15 \mathrm{E}+02$ & 5.9 \\
\hline Mn by AR & ICP-AES & $8.63 \mathrm{E}+03$ & $8.53 \mathrm{E}+03$ & $7.10 \mathrm{E}+03$ & $9.20 \mathrm{E}+03$ & $8.37 \mathrm{E}+03$ & 11 \\
\hline Mn by PF & ICP-AES & $8.69 \mathrm{E}+03$ & $8.57 \mathrm{E}+03$ & $8.60 \mathrm{E}+03$ & $8.75 \mathrm{E}+03$ & $8.65 \mathrm{E}+03$ & 1.0 \\
\hline Th by AR & ICP-AES & $9.89 \mathrm{E}+02$ & $9.50 \mathrm{E}+02$ & $8.50 \mathrm{E}+02$ & $1.21 \mathrm{E}+03$ & $1.00 \mathrm{E}+03$ & 15 \\
\hline Th by PF & ICP-AES & $1.39 \mathrm{E}+03$ & $1.37 \mathrm{E}+03$ & $1.53 \mathrm{E}+03$ & $1.51 \mathrm{E}+03$ & $1.45 \mathrm{E}+03$ & 5.6 \\
\hline U by AR & ICP-AES & $5.25 \mathrm{E}+03$ & $5.22 \mathrm{E}+03$ & $4.29 \mathrm{E}+03$ & $5.49 \mathrm{E}+03$ & $5.06 \mathrm{E}+03$ & 10 \\
\hline U by $P F$ & ICP-AES & $5.29 \mathrm{E}+03$ & $5.24 \mathrm{E}+03$ & $5.52 \mathrm{E}+03$ & $5.53 \mathrm{E}+03$ & $5.40 \mathrm{E}+03$ & 2.8 \\
\hline Th-232 & ICP-MS & $8.58 \mathrm{E}+02$ & $8.31 \mathrm{E}+02$ & $7.33 \mathrm{E}+02$ & $1.04 \mathrm{E}+03$ & $8.66 \mathrm{E}+02$ & 15 \\
\hline U-233 & ICP-MS & $9.58 \mathrm{E}-01$ & $9.45 \mathrm{E}-01$ & 7.79E-01 & $1.01 \mathrm{E}+00$ & $9.23 \mathrm{E}-01$ & 11 \\
\hline U-234 & ICP-MS & $1.19 \mathrm{E}+00$ & $1.19 \mathrm{E}+00$ & $9.71 \mathrm{E}-01$ & $1.25 \mathrm{E}+00$ & $1.15 \mathrm{E}+00$ & 11 \\
\hline U-235 & ICP-MS & $5.31 \mathrm{E}+01$ & $5.30 \mathrm{E}+01$ & $4.33 \mathrm{E}+01$ & $5.45 \mathrm{E}+01$ & $5.10 \mathrm{E}+01$ & 10 \\
\hline U-236 & ICP-MS & $2.77 \mathrm{E}+00$ & $2.80 \mathrm{E}+00$ & $2.26 \mathrm{E}+00$ & $2.87 \mathrm{E}+00$ & $2.68 \mathrm{E}+00$ & 11 \\
\hline U-238 & ICP-MS & $5.43 \mathrm{E}+03$ & $5.39 \mathrm{E}+03$ & $4.40 \mathrm{E}+03$ & $5.55 \mathrm{E}+03$ & $5.19 \mathrm{E}+03$ & 10 \\
\hline $\mathrm{Pu}-239$ & ICP-MS & $1.05 \mathrm{E}+01$ & $1.04 \mathrm{E}+01$ & $8.94 \mathrm{E}+00$ & $1.20 \mathrm{E}+01$ & $1.05 \mathrm{E}+01$ & 12 \\
\hline $\mathrm{Pu}-240$ & ICP-MS & $9.71 \mathrm{E}-01$ & $9.68 \mathrm{E}-01$ & $8.41 \mathrm{E}-01$ & $1.12 \mathrm{E}+00$ & $9.75 \mathrm{E}-01$ & 12 \\
\hline Mass 241 & ICP-MS & $6.34 \mathrm{E}-01$ & $6.36 \mathrm{E}-01$ & $5.27 \mathrm{E}-01$ & $7.38 \mathrm{E}-01$ & $6.34 \mathrm{E}-01$ & 14 \\
\hline Mass 242 & ICP-MS & $<1.83 \mathrm{E}-01$ & $<1.85 \mathrm{E}-01$ & $<1.86 \mathrm{E}-01$ & $<1.86 \mathrm{E}-01$ & $<1.85 \mathrm{E}-01$ & NA \\
\hline Mass 243 & ICP-MS & $<1.83 \mathrm{E}-01$ & $<1.85 \mathrm{E}-01$ & $<1.86 \mathrm{E}-01$ & $<1.86 \mathrm{E}-01$ & $<1.85 \mathrm{E}-01$ & NA \\
\hline Mass 244 & ICP-MS & $<9.13 \mathrm{E}-02$ & $<9.26 \mathrm{E}-02$ & $<9.29 \mathrm{E}-02$ & $<9.32 \mathrm{E}-02$ & $<9.25 \mathrm{E}-02$ & NA \\
\hline
\end{tabular}

$\mathrm{AR} \#=$ aqua regia digestion number; $\mathrm{PF} \#=$ peroxide fusion digestion number. 
Table A-3. Comparison of Replicate pH 1 Slurry Analysis Results

\begin{tabular}{|c|c|c|c|c|c|c|c|}
\hline \multirow{2}{*}{$\begin{array}{l}\text { Constituent } \\
\text { (mg/kg slurry) }\end{array}$} & \multirow{2}{*}{ Method } & \multicolumn{4}{|c|}{ Measured Concentration } & \multirow{2}{*}{ Average } & \multirow{2}{*}{$\%$ RSD } \\
\hline & & Result 1 & Result 2 & Result 3 & Result 4 & & \\
\hline Fe by AR & ICP-AES & $1.73 \mathrm{E}+04$ & $1.90 \mathrm{E}+04$ & $1.90 \mathrm{E}+04$ & $1.94 \mathrm{E}+04$ & $1.87 \mathrm{E}+04$ & 5.0 \\
\hline Fe by PF & ICP-AES & $2.64 \mathrm{E}+04$ & $2.64 \mathrm{E}+04$ & $2.68 \mathrm{E}+04$ & $2.70 \mathrm{E}+04$ & $2.67 \mathrm{E}+04$ & 1.1 \\
\hline Gd by AR & ICP-AES & $1.21 \mathrm{E}+02$ & $1.31 \mathrm{E}+02$ & $1.29 \mathrm{E}+02$ & $1.27 \mathrm{E}+02$ & $1.27 \mathrm{E}+02$ & 3.4 \\
\hline Gd by PF & ICP-AES & $1.02 \mathrm{E}+02$ & $1.11 \mathrm{E}+02$ & $1.09 \mathrm{E}+02$ & $1.00 \mathrm{E}+02$ & $1.06 \mathrm{E}+02$ & 5.0 \\
\hline Mn by AR & ICP-AES & $7.73 \mathrm{E}+03$ & $8.49 \mathrm{E}+03$ & $8.23 \mathrm{E}+03$ & $8.30 \mathrm{E}+03$ & $8.19 \mathrm{E}+03$ & 4.0 \\
\hline Mn by PF & ICP-AES & $8.38 \mathrm{E}+03$ & $8.31 \mathrm{E}+03$ & $8.42 \mathrm{E}+03$ & $8.46 \mathrm{E}+03$ & $8.39 \mathrm{E}+03$ & 0.8 \\
\hline Th by AR & ICP-AES & $9.68 \mathrm{E}+02$ & $1.07 \mathrm{E}+03$ & $1.07 \mathrm{E}+03$ & $1.08 \mathrm{E}+03$ & $1.05 \mathrm{E}+03$ & 5.1 \\
\hline Th by PF & ICP-AES & $1.49 \mathrm{E}+03$ & $1.43 \mathrm{E}+03$ & $1.47 \mathrm{E}+03$ & $1.47 \mathrm{E}+03$ & $1.47 \mathrm{E}+03$ & 1.7 \\
\hline U by AR & ICP-AES & $4.61 \mathrm{E}+03$ & $5.07 \mathrm{E}+03$ & $4.92 \mathrm{E}+03$ & $4.98 \mathrm{E}+03$ & $4.90 \mathrm{E}+03$ & 4.1 \\
\hline U by $P F$ & ICP-AES & $5.26 \mathrm{E}+03$ & $5.23 \mathrm{E}+03$ & $5.23 \mathrm{E}+03$ & $5.18 \mathrm{E}+03$ & $5.23 \mathrm{E}+03$ & 0.6 \\
\hline Th-232 & ICP-MS & $8.45 \mathrm{E}+02$ & $9.43 \mathrm{E}+02$ & $9.35 \mathrm{E}+02$ & $9.59 \mathrm{E}+02$ & $9.21 \mathrm{E}+02$ & 5.6 \\
\hline U-233 & ICP-MS & $8.62 \mathrm{E}-01$ & $9.38 \mathrm{E}-01$ & $9.14 \mathrm{E}-01$ & $9.15 \mathrm{E}-01$ & $9.07 \mathrm{E}-01$ & 3.5 \\
\hline U-234 & ICP-MS & $1.07 \mathrm{E}+00$ & $1.19 \mathrm{E}+00$ & $1.13 \mathrm{E}+00$ & $1.14 \mathrm{E}+00$ & $1.13 \mathrm{E}+00$ & 4.3 \\
\hline U-235 & ICP-MS & $4.65 \mathrm{E}+01$ & $5.19 \mathrm{E}+01$ & $4.95 \mathrm{E}+01$ & $5.05 \mathrm{E}+01$ & $4.96 \mathrm{E}+01$ & 4.6 \\
\hline U-236 & ICP-MS & $2.49 \mathrm{E}+00$ & $2.73 \mathrm{E}+00$ & $2.65 \mathrm{E}+00$ & $2.68 \mathrm{E}+00$ & $2.64 \mathrm{E}+00$ & 3.9 \\
\hline U-238 & ICP-MS & $4.71 \mathrm{E}+03$ & $5.28 \mathrm{E}+03$ & $5.07 \mathrm{E}+03$ & $5.09 \mathrm{E}+03$ & $5.04 \mathrm{E}+03$ & 4.7 \\
\hline $\mathrm{Pu}-239$ & ICP-MS & $1.00 \mathrm{E}+01$ & $1.13 \mathrm{E}+01$ & $1.12 \mathrm{E}+01$ & $1.13 \mathrm{E}+01$ & $1.10 \mathrm{E}+01$ & 5.8 \\
\hline $\mathrm{Pu}-240$ & ICP-MS & $9.26 \mathrm{E}-01$ & $1.05 \mathrm{E}+00$ & $1.05 \mathrm{E}+00$ & $1.06 \mathrm{E}+00$ & $1.02 \mathrm{E}+00$ & 6.2 \\
\hline Mass 241 & ICP-MS & $6.05 \mathrm{E}-01$ & $6.68 \mathrm{E}-01$ & $6.57 \mathrm{E}-01$ & $6.76 \mathrm{E}-01$ & $6.52 \mathrm{E}-01$ & 4.9 \\
\hline Mass 242 & ICP-MS & $<1.71 \mathrm{E}-01$ & $<1.69 \mathrm{E}-01$ & $<1.78 \mathrm{E}-01$ & $<1.82 \mathrm{E}-01$ & $<1.75 \mathrm{E}-01$ & NA \\
\hline Mass 243 & ICP-MS & $<1.71 \mathrm{E}-01$ & $<1.69 \mathrm{E}-01$ & $<1.78 \mathrm{E}-01$ & $<1.82 \mathrm{E}-01$ & $<1.75 \mathrm{E}-01$ & NA \\
\hline Mass 244 & ICP-MS & $<8.54 \mathrm{E}-02$ & $<8.47 \mathrm{E}-02$ & $<8.89 \mathrm{E}-02$ & $<9.08 \mathrm{E}-02$ & $<8.75 \mathrm{E}-02$ & NA \\
\hline
\end{tabular}

$\mathrm{AR} \#=$ aqua regia digestion number; $\mathrm{PF} \#=$ peroxide fusion digestion number. 
Table A-4. Replicate Radiochemical Analysis of pH 3 Slurry (dpm/g of slurry)

\begin{tabular}{|c|c|c|c|c|c|c|c|c|}
\hline \multirow{2}{*}{$\begin{array}{c}\text { Constituent } \\
\text { (dpm/g } \\
\text { slurry) }\end{array}$} & \multicolumn{2}{|c|}{ Result 1} & \multicolumn{2}{|c|}{ Result 2} & \multicolumn{2}{|c|}{ Result 3} & \multicolumn{2}{|c|}{ Result 4} \\
\hline & Measurement & $\begin{array}{c}1 \sigma \\
\text { unc. }\end{array}$ & Measurement & $\begin{array}{c}1 \sigma \\
\text { unc. }\end{array}$ & Measurement & $\begin{array}{c}1 \sigma \\
\text { unc. }\end{array}$ & Measurement & $1 \sigma$ unc. \\
\hline $\mathrm{Pu}-238$ & $5.96 \mathrm{E}+07$ & $7.1 \%$ & $6.26 \mathrm{E}+07$ & $7.3 \%$ & $6.57 \mathrm{E}+07$ & $6.1 \%$ & $6.99 \mathrm{E}+07$ & $7.9 \%$ \\
\hline $\mathrm{Pu}-239 / 240$ & $3.45 \mathrm{E}+06$ & $7.4 \%$ & $3.59 \mathrm{E}+06$ & $7.7 \%$ & $3.66 \mathrm{E}+06$ & $6.3 \%$ & $3.82 \mathrm{E}+06$ & $8.2 \%$ \\
\hline Am-241 & $7.20 \mathrm{E}+06$ & $5.0 \%$ & $7.55 \mathrm{E}+06$ & $5.0 \%$ & $8.29 \mathrm{E}+06$ & $5.0 \%$ & $7.88 \mathrm{E}+06$ & $5.0 \%$ \\
\hline Am-243 & $6.27 \mathrm{E}+04$ & $12 \%$ & $6.56 \mathrm{E}+04$ & $12 \%$ & $6.91 \mathrm{E}+04$ & $12 \%$ & $6.98 \mathrm{E}+04$ & $13 \%$ \\
\hline Am-242m & $9.53 \mathrm{E}+03$ & $17 \%$ & $9.70 \mathrm{E}+03$ & $14 \%$ & $8.10 \mathrm{E}+03$ & $17 \%$ & $1.13 \mathrm{E}+04$ & $13 \%$ \\
\hline $\mathrm{Cm}-243$ & $<6.06 \mathrm{E}+04$ & NA & $<5.41 \mathrm{E}+04$ & NA & $<5.94 \mathrm{E}+04$ & NA & $<4.57 \mathrm{E}+04$ & NA \\
\hline $\mathrm{Cm}-245$ & $<5.06 \mathrm{E}+04$ & NA & $<4.53 \mathrm{E}+04$ & NA & $<4.98 \mathrm{E}+04$ & NA & $<3.74 \mathrm{E}+04$ & NA \\
\hline $\mathrm{Cm}-247$ & $<2.98 \mathrm{E}+04$ & NA & $<2.44 \mathrm{E}+04$ & NA & $<2.79 \mathrm{E}+04$ & NA & $<3.66 \mathrm{E}+04$ & NA \\
\hline $\mathrm{Cm}-242$ & $7.88 \mathrm{E}+03$ & $17 \%$ & $8.02 \mathrm{E}+03$ & $14 \%$ & $6.70 \mathrm{E}+03$ & $17 \%$ & $9.37 \mathrm{E}+03$ & $13 \%$ \\
\hline $\mathrm{Cm}-244$ & $2.59 \mathrm{E}+06$ & $15 \%$ & $2.61 \mathrm{E}+06$ & $15 \%$ & $2.93 \mathrm{E}+06$ & $15 \%$ & $2.93 \mathrm{E}+06$ & $15 \%$ \\
\hline
\end{tabular}

Table A-5. Replicate Radiochemical Analysis of pH 2 Slurry (dpm/g of slurry)

\begin{tabular}{|c|c|c|c|c|c|c|c|c||}
\hline \multirow{2}{*}{$\begin{array}{c}\text { Constituent } \\
\text { (dpm/g } \\
\text { slurry }\end{array}$} & \multicolumn{2}{|c|}{ Result 1 } & \multicolumn{2}{c|}{ Result 2 } & \multicolumn{2}{c||}{ Result 3 } & \multicolumn{2}{c||}{ Result 4 } \\
\cline { 2 - 10 } & Measurement & $\begin{array}{c}\mathbf{1 \sigma} \\
\text { unc. }\end{array}$ & Measurement & $\begin{array}{c}\mathbf{1 \sigma} \\
\text { unc. }\end{array}$ & Measurement & $\begin{array}{c}\mathbf{1 \sigma} \\
\text { unc. }\end{array}$ & Measurement & $\begin{array}{c}\mathbf{1 \sigma} \\
\text { unc. }\end{array}$ \\
\hline $\mathrm{Pu}-238$ & $5.82 \mathrm{E}+07$ & $7.6 \%$ & $5.29 \mathrm{E}+07$ & $6.8 \%$ & $5.27 \mathrm{E}+07$ & $5.9 \%$ & $6.02 \mathrm{E}+07$ & $6.7 \%$ \\
\hline $\mathrm{Pu}-239 / 240$ & $3.20 \mathrm{E}+06$ & $7.9 \%$ & $2.94 \mathrm{E}+06$ & $7.1 \%$ & $3.04 \mathrm{E}+06$ & $6.1 \%$ & $3.39 \mathrm{E}+06$ & $6.9 \%$ \\
\hline $\mathrm{Am}-241$ & $7.36 \mathrm{E}+06$ & $5.0 \%$ & $7.05 \mathrm{E}+06$ & $5.0 \%$ & $6.89 \mathrm{E}+06$ & $5.0 \%$ & $6.73 \mathrm{E}+06$ & $5.0 \%$ \\
\hline $\mathrm{Am}-243$ & $6.36 \mathrm{E}+04$ & $12 \%$ & $5.38 \mathrm{E}+04$ & $12 \%$ & $5.74 \mathrm{E}+04$ & $12 \%$ & $5.81 \mathrm{E}+04$ & $12 \%$ \\
\hline $\mathrm{Am}-242 \mathrm{~m}$ & $7.21 \mathrm{E}+03$ & $19 \%$ & $7.68 \mathrm{E}+03$ & $16 \%$ & $7.76 \mathrm{E}+03$ & $16 \%$ & $8.00 \mathrm{E}+03$ & $14 \%$ \\
\hline $\mathrm{Cm}-243$ & $<4.78 \mathrm{E}+04$ & NA & $<4.72 \mathrm{E}+04$ & NA & $<5.43 \mathrm{E}+04$ & NA & $<6.74 \mathrm{E}+04$ & NA \\
\hline $\mathrm{Cm}-245$ & $<4.00 \mathrm{E}+04$ & NA & $<3.95 \mathrm{E}+04$ & NA & $<4.54 \mathrm{E}+04$ & NA & $<5.26 \mathrm{E}+04$ & NA \\
\hline $\mathrm{Cm}-247$ & $<2.13 \mathrm{E}+04$ & NA & $<2.19 \mathrm{E}+04$ & NA & $<2.54 \mathrm{E}+04$ & NA & $<1.96 \mathrm{E}+04$ & NA \\
\hline $\mathrm{Cm}-242$ & $5.97 \mathrm{E}+03$ & $19 \%$ & $6.35 \mathrm{E}+03$ & $16 \%$ & $6.42 \mathrm{E}+03$ & $16 \%$ & $6.62 \mathrm{E}+03$ & $14 \%$ \\
\hline $\mathrm{Cm}-244$ & $2.71 \mathrm{E}+06$ & $15 \%$ & $2.58 \mathrm{E}+06$ & $15.1 \%$ & $2.62 \mathrm{E}+06$ & $15 \%$ & $2.38 \mathrm{E}+06$ & $15 \%$ \\
\hline
\end{tabular}


Table A-6. Replicate Radiochemical Analysis of pH 1 Slurry (dpm/g of slurry)

\begin{tabular}{|c|c|c|c|c|c|c|c|c||}
\hline \multirow{2}{*}{$\begin{array}{c}\text { Constituent } \\
\left(\begin{array}{c}\text { dpm/g } \\
\text { slurry) }\end{array}\right.\end{array}$} & \multicolumn{2}{|c|}{ Result 1 } & \multicolumn{2}{c|}{ Result 2 } & \multicolumn{2}{c||}{ Result 3 } & \multicolumn{2}{c||}{ Result 4 } \\
\cline { 2 - 10 } & Measurement & $\begin{array}{c}\mathbf{1 \sigma} \\
\text { unc. }\end{array}$ & Measurement & $\begin{array}{c}\mathbf{1 \sigma} \\
\text { unc. }\end{array}$ & Measurement & $\begin{array}{c}\mathbf{1 \sigma} \\
\text { unc. }\end{array}$ & Measurement & $\begin{array}{c}\mathbf{1 \sigma} \\
\text { unc. }\end{array}$ \\
\hline $\mathrm{Pu}-238$ & $5.59 \mathrm{E}+07$ & $5.81 \%$ & $5.75 \mathrm{E}+07$ & $6.79 \%$ & $5.52 \mathrm{E}+07$ & $6.48 \%$ & $5.38 \mathrm{E}+07$ & $7.61 \%$ \\
\hline $\mathrm{Pu}-239 / 240$ & $3.16 \mathrm{E}+06$ & $6.08 \%$ & $3.13 \mathrm{E}+06$ & $7.09 \%$ & $3.01 \mathrm{E}+06$ & $6.71 \%$ & $2.99 \mathrm{E}+06$ & $7.83 \%$ \\
\hline $\mathrm{Am}-241$ & $6.81 \mathrm{E}+06$ & $5.00 \%$ & $6.59 \mathrm{E}+06$ & $5.00 \%$ & $6.72 \mathrm{E}+06$ & $5.00 \%$ & $6.36 \mathrm{E}+06$ & $5.00 \%$ \\
\hline $\mathrm{Am}-243$ & $5.47 \mathrm{E}+04$ & $12.1 \%$ & $5.44 \mathrm{E}+04$ & $15.1 \%$ & $5.43 \mathrm{E}+04$ & $11.9 \%$ & $5.06 \mathrm{E}+04$ & $12.2 \%$ \\
\hline $\mathrm{Am}-242 \mathrm{~m}$ & $8.35 \mathrm{E}+03$ & $15.3 \%$ & $8.48 \mathrm{E}+03$ & $23.9 \%$ & $4.53 \mathrm{E}+03$ & $28.5 \%$ & $4.21 \mathrm{E}+03$ & $28.5 \%$ \\
\hline $\mathrm{Cm}-243$ & $<6.01 \mathrm{E}+04$ & NA & $<1.03 \mathrm{E}+05$ & NA & $<5.89 \mathrm{E}+04$ & NA & $<9.68 \mathrm{E}+04$ & NA \\
\hline $\mathrm{Cm}-245$ & $<5.04 \mathrm{E}+04$ & NA & $<8.60 \mathrm{E}+04$ & NA & $<6.72 \mathrm{E}+06$ & NA & $<6.36 \mathrm{E}+06$ & NA \\
\hline $\mathrm{Cm}-247$ & $<2.56 \mathrm{E}+04$ & NA & $<4.79 \mathrm{E}+04$ & NA & $<2.67 \mathrm{E}+04$ & NA & $<2.18 \mathrm{E}+04$ & NA \\
\hline $\mathrm{Cm}-242$ & $6.91 \mathrm{E}+03$ & $15 \%$ & $7.01 \mathrm{E}+03$ & $24 \%$ & $3.75 \mathrm{E}+03$ & $29 \%$ & $3.48 \mathrm{E}+03$ & $29 \%$ \\
\hline $\mathrm{Cm}-244$ & $2.51 \mathrm{E}+06$ & $15.1 \%$ & $2.47 \mathrm{E}+06$ & $15.1 \%$ & $2.50 \mathrm{E}+06$ & $15.1 \%$ & $2.26 \mathrm{E}+06$ & $15.1 \%$ \\
\hline
\end{tabular}

Table A-7. Replicate Analysis of pH 3 Filtrate

\begin{tabular}{|c|c|c|c|c|c|c|c||}
\hline \hline \multirow{2}{*}{$\begin{array}{c}\text { Constituent } \\
\text { mg/kg filtrate) }\end{array}$} & \multirow{2}{*}{ Method } & \multicolumn{7}{|c|}{ Measured Concentration } & \\
\cline { 3 - 8 } & & Result 1 & Result 2 & Result 3 & Result 4 & Average & \%RSD \\
\hline Fe & ICP-AES & $1.31 \mathrm{E}+03$ & $1.39 \mathrm{E}+03$ & $1.57 \mathrm{E}+03$ & $1.65 \mathrm{E}+03$ & $1.48 \mathrm{E}+03$ & 11 \\
\hline $\mathrm{Gd}$ & ICP-AES & $8.17 \mathrm{E}+01$ & $8.33 \mathrm{E}+01$ & $8.83 \mathrm{E}+01$ & $8.83 \mathrm{E}+01$ & $8.54 \mathrm{E}+01$ & 4.0 \\
\hline $\mathrm{Mn}$ & ICP-AES & $5.94 \mathrm{E}+03$ & $6.09 \mathrm{E}+03$ & $6.58 \mathrm{E}+03$ & $6.70 \mathrm{E}+03$ & $6.33 \mathrm{E}+03$ & 5.8 \\
\hline Th & ICP-AES & $1.63 \mathrm{E}+02$ & $1.63 \mathrm{E}+02$ & $1.66 \mathrm{E}+02$ & $1.68 \mathrm{E}+02$ & $1.65 \mathrm{E}+02$ & 1.6 \\
\hline U & ICP-AES & $6.12 \mathrm{E}+03$ & $6.03 \mathrm{E}+03$ & $6.28 \mathrm{E}+03$ & $6.24 \mathrm{E}+03$ & $6.17 \mathrm{E}+03$ & 1.8 \\
\hline Th-232 & ICP-MS & $4.80 \mathrm{E}+01$ & $4.87 \mathrm{E}+01$ & $5.50 \mathrm{E}+01$ & $5.62 \mathrm{E}+01$ & $5.19 \mathrm{E}+01$ & 8.2 \\
\hline $\mathrm{U}-233$ & ICP-MS & $9.55 \mathrm{E}-01$ & $9.42 \mathrm{E}-01$ & $9.73 \mathrm{E}-01$ & $9.95 \mathrm{E}-01$ & $9.70 \mathrm{E}-01$ & 2.4 \\
\hline $\mathrm{U}-234$ & ICP-MS & $1.21 \mathrm{E}+00$ & $1.21 \mathrm{E}+00$ & $1.26 \mathrm{E}+00$ & $1.30 \mathrm{E}+00$ & $1.24 \mathrm{E}+00$ & 3.4 \\
\hline $\mathrm{U}-235$ & ICP-MS & $5.80 \mathrm{E}+01$ & $5.83 \mathrm{E}+01$ & $6.07 \mathrm{E}+01$ & $6.08 \mathrm{E}+01$ & $5.95 \mathrm{E}+01$ & 2.5 \\
\hline $\mathrm{U}-236$ & ICP-MS & $3.42 \mathrm{E}+00$ & $3.39 \mathrm{E}+00$ & $3.51 \mathrm{E}+00$ & $3.59 \mathrm{E}+00$ & $3.48 \mathrm{E}+00$ & 2.6 \\
\hline $\mathrm{U}-238$ & ICP-MS & $6.09 \mathrm{E}+03$ & $6.11 \mathrm{E}+03$ & $6.38 \mathrm{E}+03$ & $6.37 \mathrm{E}+03$ & $6.24 \mathrm{E}+03$ & 2.6 \\
\hline Pu-239 & ICP-MS & $2.78 \mathrm{E}+00$ & $2.81 \mathrm{E}+00$ & $3.07 \mathrm{E}+00$ & $3.17 \mathrm{E}+00$ & $2.96 \mathrm{E}+00$ & 6.5 \\
\hline Pu-240 & ICP-MS & $2.10 \mathrm{E}-01$ & $2.13 \mathrm{E}-01$ & $2.26 \mathrm{E}-01$ & $2.40 \mathrm{E}-01$ & $2.22 \mathrm{E}-01$ & 6.1 \\
\hline
\end{tabular}


Table A-8. Replicate Analysis of pH 2 Filtrate

\begin{tabular}{|c|c|c|c|c|c|c|c||}
\hline \multirow{2}{*}{$\begin{array}{c}\text { Constituent } \\
\text { mg/kg filtrate) }\end{array}$} & \multirow{2}{*}{ Method } & \multicolumn{7}{|c|}{ Measured Concentration } & \multicolumn{1}{c||}{} \\
\cline { 3 - 8 } & & Result 1 & Result 2 & Result 3 & Result 4 & Average & \%RSD \\
\hline Fe & ICP-AES & $1.57 \mathrm{E}+03$ & $1.64 \mathrm{E}+03$ & $1.70 \mathrm{E}+03$ & $1.76 \mathrm{E}+03$ & $1.67 \mathrm{E}+03$ & 4.9 \\
\hline Gd & ICP-AES & $8.27 \mathrm{E}+01$ & $8.51 \mathrm{E}+01$ & $8.58 \mathrm{E}+01$ & $8.60 \mathrm{E}+01$ & $8.49 \mathrm{E}+01$ & 1.8 \\
\hline $\mathrm{Mn}$ & ICP-AES & $6.54 \mathrm{E}+03$ & $6.67 \mathrm{E}+03$ & $6.73 \mathrm{E}+03$ & $6.87 \mathrm{E}+03$ & $6.70 \mathrm{E}+03$ & 2.0 \\
\hline Th & ICP-AES & $1.58 \mathrm{E}+02$ & $1.52 \mathrm{E}+02$ & $1.56 \mathrm{E}+02$ & $1.59 \mathrm{E}+02$ & $1.66 \mathrm{E}+02$ & 2.0 \\
\hline U & ICP-AES & $5.74 \mathrm{E}+03$ & $5.72 \mathrm{E}+03$ & $5.67 \mathrm{E}+03$ & $5.77 \mathrm{E}+03$ & $5.73 \mathrm{E}+03$ & 0.7 \\
\hline Th-232 & ICP-MS & $5.02 \mathrm{E}+01$ & $5.24 \mathrm{E}+01$ & $5.48 \mathrm{E}+01$ & $5.59 \mathrm{E}+01$ & $5.33 \mathrm{E}+01$ & 4.8 \\
\hline U-233 & ICP-MS & $8.90 \mathrm{E}-01$ & $8.80 \mathrm{E}-01$ & $8.77 \mathrm{E}-01$ & $8.91 \mathrm{E}-01$ & $8.84 \mathrm{E}-01$ & 0.8 \\
\hline U-234 & ICP-MS & $1.14 \mathrm{E}+00$ & $1.17 \mathrm{E}+00$ & $1.15 \mathrm{E}+00$ & $1.17 \mathrm{E}+00$ & $1.16 \mathrm{E}+00$ & 1.3 \\
\hline U-235 & ICP-MS & $5.50 \mathrm{E}+01$ & $5.53 \mathrm{E}+01$ & $5.50 \mathrm{E}+01$ & $5.54 \mathrm{E}+01$ & $5.52 \mathrm{E}+01$ & 0.4 \\
\hline U-236 & ICP-MS & $3.23 \mathrm{E}+00$ & $3.17 \mathrm{E}+00$ & $3.16 \mathrm{E}+00$ & $3.17 \mathrm{E}+00$ & $3.18 \mathrm{E}+00$ & 0.9 \\
\hline U-238 & ICP-MS & $5.79 \mathrm{E}+03$ & $5.82 \mathrm{E}+03$ & $5.76 \mathrm{E}+03$ & $5.83 \mathrm{E}+03$ & $5.80 \mathrm{E}+03$ & 0.5 \\
\hline Pu-239 & ICP-MS & $3.02 \mathrm{E}+00$ & $3.06 \mathrm{E}+00$ & $3.14 \mathrm{E}+00$ & $3.24 \mathrm{E}+00$ & $3.12 \mathrm{E}+00$ & 3.1 \\
\hline Pu-240 & ICP-MS & $2.27 \mathrm{E}-01$ & $2.34 \mathrm{E}-01$ & $2.37 \mathrm{E}-01$ & $2.44 \mathrm{E}-01$ & $2.36 \mathrm{E}-01$ & 3.0 \\
\hline
\end{tabular}

Table A-9. Replicate Analysis of pH 1 Filtrate

\begin{tabular}{|c|c|c|c|c|c|c|c||}
\hline \multirow{2}{*}{$\begin{array}{c}\text { Constituent } \\
\text { mg/kg filtrate) }\end{array}$} & \multirow{2}{*}{ Method } & \multicolumn{7}{|c|}{ Measured Concentration } & \\
\cline { 3 - 8 } & & Result 1 & Result 2 & Result 3 & Result 4 & Average & \%RSD \\
\hline Fe & ICP-AES & $2.09 \mathrm{E}+03$ & $2.10 \mathrm{E}+03$ & $2.12 \mathrm{E}+03$ & $2.14 \mathrm{E}+03$ & $2.11 \mathrm{E}+03$ & 1.0 \\
\hline Gd & ICP-AES & $9.83 \mathrm{E}+01$ & $1.00 \mathrm{E}+02$ & $9.74 \mathrm{E}+01$ & $9.92 \mathrm{E}+01$ & $9.88 \mathrm{E}+01$ & 1.2 \\
\hline $\mathrm{Mn}$ & ICP-AES & $7.31 \mathrm{E}+03$ & $7.40 \mathrm{E}+03$ & $7.28 \mathrm{E}+03$ & $7.36 \mathrm{E}+03$ & $7.34 \mathrm{E}+03$ & 0.7 \\
\hline Th & ICP-AES & $1.65 \mathrm{E}+02$ & $1.63 \mathrm{E}+02$ & $1.64 \mathrm{E}+02$ & $1.68 \mathrm{E}+02$ & $1.65 \mathrm{E}+02$ & 1.3 \\
\hline U & ICP-AES & $5.59 \mathrm{E}+03$ & $5.60 \mathrm{E}+03$ & $5.50 \mathrm{E}+03$ & $5.56 \mathrm{E}+03$ & $5.56 \mathrm{E}+03$ & 0.8 \\
\hline Th-232 & ICP-MS & $6.23 \mathrm{E}+01$ & $6.36 \mathrm{E}+01$ & $6.29 \mathrm{E}+01$ & $6.42 \mathrm{E}+01$ & $6.32 \mathrm{E}+01$ & 1.3 \\
\hline $\mathrm{U}-233$ & ICP-MS & $8.58 \mathrm{E}-01$ & $8.64 \mathrm{E}-01$ & $8.40 \mathrm{E}-01$ & $8.52 \mathrm{E}-01$ & $8.53 \mathrm{E}-01$ & 1.2 \\
\hline $\mathrm{U}-234$ & ICP-MS & $1.13 \mathrm{E}+00$ & $1.13 \mathrm{E}+00$ & $1.11 \mathrm{E}+00$ & $1.15 \mathrm{E}+00$ & $1.13 \mathrm{E}+00$ & 1.8 \\
\hline $\mathrm{U}-235$ & ICP-MS & $5.32 \mathrm{E}+01$ & $5.27 \mathrm{E}+01$ & $5.30 \mathrm{E}+01$ & $5.33 \mathrm{E}+01$ & $5.30 \mathrm{E}+01$ & 0.5 \\
\hline $\mathrm{U}-236$ & ICP-MS & $3.07 \mathrm{E}+00$ & $3.11 \mathrm{E}+00$ & $3.02 \mathrm{E}+00$ & $3.08 \mathrm{E}+00$ & $3.07 \mathrm{E}+00$ & 1.1 \\
\hline $\mathrm{U}-238$ & ICP-MS & $5.59 \mathrm{E}+03$ & $5.56 \mathrm{E}+03$ & $5.54 \mathrm{E}+03$ & $5.59 \mathrm{E}+03$ & $5.57 \mathrm{E}+03$ & 0.4 \\
\hline Pu-239 & ICP-MS & $3.74 \mathrm{E}+00$ & $3.81 \mathrm{E}+00$ & $3.71 \mathrm{E}+00$ & $3.82 \mathrm{E}+00$ & $3.77 \mathrm{E}+00$ & 1.4 \\
\hline Pu-240 & ICP-MS & $2.89 \mathrm{E}-01$ & $2.87 \mathrm{E}-01$ & $2.78 \mathrm{E}-01$ & $2.97 \mathrm{E}-01$ & $2.88 \mathrm{E}-01$ & 2.7 \\
\hline \hline
\end{tabular}


Table A-10. Replicate Radiochemical Analysis of pH 3 Supernatant (dpm/mL of filtrate)

\begin{tabular}{|c|c|c|c|c|c|c|c|c||}
\hline \multirow{2}{*}{$\begin{array}{c}\text { Constituent } \\
\text { (dpm/mL } \\
\text { filtrate) }\end{array}$} & \multicolumn{2}{|c|}{ Result 1 } & \multicolumn{2}{c|}{ Result 2 } & \multicolumn{2}{c|}{ Result 3 } & \multicolumn{2}{c||}{ Result 4 } \\
\cline { 2 - 10 } & Measurement & $\begin{array}{c}\mathbf{1 \sigma} \\
\text { unc. }\end{array}$ & Measurement & $\begin{array}{c}\mathbf{1 \sigma} \\
\text { unc. }\end{array}$ & Measurement & $\begin{array}{c}\mathbf{1 \sigma} \\
\text { unc. }\end{array}$ & Measurement & 1 $\boldsymbol{\sigma}$ unc. \\
\hline $\mathrm{Pu}-238$ & $4.31 \mathrm{E}+06$ & $9.4 \%$ & $4.07 \mathrm{E}+06$ & $7.6 \%$ & $5.16 \mathrm{E}+06$ & $8.0 \%$ & $6.57 \mathrm{E}+06$ & $10 \%$ \\
\hline $\mathrm{Pu}-239 / 240$ & $4.37 \mathrm{E}+05$ & $9.6 \%$ & $4.92 \mathrm{E}+05$ & $7.8 \%$ & $5.31 \mathrm{E}+05$ & $8.1 \%$ & $6.53 \mathrm{E}+05$ & $10 \%$ \\
\hline $\mathrm{Am}-241$ & $1.71 \mathrm{E}+06$ & $14 \%$ & $1.57 \mathrm{E}+06$ & $13 \%$ & $1.74 \mathrm{E}+06$ & $14 \%$ & $1.87 \mathrm{E}+06$ & $14 \%$ \\
\hline $\mathrm{Am}-243$ & $1.78 \mathrm{E}+04$ & $18 \%$ & $1.60 \mathrm{E}+04$ & $17 \%$ & $1.89 \mathrm{E}+04$ & $18 \%$ & $1.94 \mathrm{E}+04$ & $18 \%$ \\
\hline $\mathrm{Am}-242 m$ & $2.43 \mathrm{E}+03$ & $21 \%$ & $2.82 \mathrm{E}+03$ & $16 \%$ & $2.67 \mathrm{E}+03$ & $16 \%$ & $3.06 \mathrm{E}+03$ & $18 \%$ \\
\hline $\mathrm{Cm}-243$ & $<1.42 \mathrm{E}+04$ & NA & $<1.25 \mathrm{E}+04$ & NA & $<1.44 \mathrm{E}+04$ & NA & $<6.17 \mathrm{E}+04$ & NA \\
\hline $\mathrm{Cm}-245$ & $<1.19 \mathrm{E}+04$ & NA & $<1.04 \mathrm{E}+04$ & NA & $<1.20 \mathrm{E}+04$ & NA & $<1.61 \mathrm{E}+04$ & NA \\
\hline $\mathrm{Cm}-247$ & $<5.73 \mathrm{E}+03$ & NA & $<5.12 \mathrm{E}+03$ & NA & $<6.87 \mathrm{E}+03$ & NA & $<5.42 \mathrm{E}+03$ & NA \\
\hline $\mathrm{Cm}-242$ & $2.01 \mathrm{E}+03$ & $21 \%$ & $2.34 \mathrm{E}+03$ & $16 \%$ & $2.21 \mathrm{E}+03$ & $16 \%$ & $2.54 \mathrm{E}+03$ & $18 \%$ \\
\hline $\mathrm{Cm}-244$ & $1.19 \mathrm{E}+06$ & $19 \%$ & $9.64 \mathrm{E}+05$ & $18 \%$ & $1.01 \mathrm{E}+06$ & $19 \%$ & $1.14 \mathrm{E}+06$ & $19 \%$ \\
\hline
\end{tabular}

Table A-11. Replicate Radiochemical Analysis of pH 2 Supernatant (dpm/ $\mathrm{mL}$ of filtrate)

\begin{tabular}{|c|c|c|c|c|c|c|c|c||}
\hline \hline $\begin{array}{c}\text { Constituent } \\
\text { (dpm/mL } \\
\text { filtrate) }\end{array}$ & \multicolumn{2}{|c|}{ Result 1 } & \multicolumn{2}{c|}{ Result 2 } & \multicolumn{2}{c|}{ Result 3 } & \multicolumn{3}{c||}{ Result 4 } \\
\cline { 2 - 10 } & Measurement & $\begin{array}{c}\mathbf{1 \sigma} \\
\text { unc. }\end{array}$ & Measurement & $\begin{array}{c}\mathbf{1 \sigma} \\
\text { unc. }\end{array}$ & Measurement & $\begin{array}{c}\mathbf{1 \sigma} \\
\text { unc. }\end{array}$ & Measurement & $\begin{array}{c}\mathbf{1 \sigma} \\
\text { unc. }\end{array}$ \\
\hline $\mathrm{Pu}-238$ & $6.11 \mathrm{E}+06$ & $11 \%$ & $5.19 \mathrm{E}+06$ & $11 \%$ & $6.83 \mathrm{E}+06$ & $11 \%$ & $6.87 \mathrm{E}+06$ & $11 \%$ \\
\hline $\mathrm{Pu}-239 / 240$ & $6.32 \mathrm{E}+05$ & $11 \%$ & $5.24 \mathrm{E}+05$ & $11 \%$ & $6.96 \mathrm{E}+05$ & $11 \%$ & $6.89 \mathrm{E}+05$ & $11 \%$ \\
\hline $\mathrm{Am}-241$ & $7.90 \mathrm{E}+06$ & $56 \%$ & $1.53 \mathrm{E}+06$ & $12 \%$ & $1.98 \mathrm{E}+06$ & $17 \%$ & $2.23 \mathrm{E}+06$ & $18 \%$ \\
\hline $\mathrm{Am}-243$ & $1.64 \mathrm{E}+05$ & $57 \%$ & $1.60 \mathrm{E}+04$ & $17 \%$ & $2.03 \mathrm{E}+04$ & $20 \%$ & $2.27 \mathrm{E}+04$ & $21 \%$ \\
\hline $\mathrm{Am}-242 m$ & $1.12 \mathrm{E}+04$ & $56 \%$ & $2.37 \mathrm{E}+03$ & $23 \%$ & $3.15 \mathrm{E}+03$ & $19 \%$ & $2.57 \mathrm{E}+03$ & $24 \%$ \\
\hline $\mathrm{Cm}-243$ & $<6.39 \mathrm{E}+04$ & NA & $<1.50 \mathrm{E}+04$ & NA & $<1.42 \mathrm{E}+04$ & NA & $<6.38 \mathrm{E}+04$ & NA \\
\hline $\mathrm{Cm}-245$ & $<5.35 \mathrm{E}+04$ & NA & $<1.25 \mathrm{E}+04$ & NA & $<1.20 \mathrm{E}+04$ & NA & $<1.67 \mathrm{E}+04$ & NA \\
\hline $\mathrm{Cm}-247$ & $<2.40 \mathrm{E}+04$ & NA & $<7.22 \mathrm{E}+03$ & NA & $<5.58 \mathrm{E}+03$ & NA & $<5.57 \mathrm{E}+03$ & NA \\
\hline $\mathrm{Cm}-242$ & $9.34 \mathrm{E}+03$ & $56 \%$ & $1.96 \mathrm{E}+03$ & $23 \%$ & $2.60 \mathrm{E}+03$ & $19 \%$ & $2.13 \mathrm{E}+03$ & $24 \%$ \\
\hline $\mathrm{Cm}-244$ & $4.62 \mathrm{E}+06$ & $61 \%$ & $1.08 \mathrm{E}+06$ & $17 \%$ & $1.16 \mathrm{E}+06$ & $22 \%$ & $1.50 \mathrm{E}+06$ & $23 \%$ \\
\hline
\end{tabular}


Table A-12. Replicate Radiochemical Analysis of pH 1 Supernatant (dpm/mL of filtrate)

\begin{tabular}{|c|c|c|c|c|c|c|c|c|}
\hline \multirow{2}{*}{$\begin{array}{l}\text { Constituent } \\
\text { (dpm/mL } \\
\text { filtrate) }\end{array}$} & \multicolumn{2}{|c|}{ Result 1} & \multicolumn{2}{|l|}{ Result 2} & \multicolumn{2}{|l|}{ Result 3} & \multicolumn{2}{|c|}{ Result 4} \\
\hline & Measurement & $\begin{array}{c}1 \sigma \\
\text { unc. }\end{array}$ & Measurement & $\begin{array}{c}1 \sigma \\
\text { unc. }\end{array}$ & Measurement & $\begin{array}{c}1 \sigma \\
\text { unc. }\end{array}$ & Measurement & $\begin{array}{c}1 \sigma \\
\text { unc. }\end{array}$ \\
\hline $\mathrm{Pu}-238$ & $7.24 \mathrm{E}+06$ & $7.8 \%$ & $6.80 \mathrm{E}+06$ & $8.4 \%$ & $6.33 \mathrm{E}+06$ & $7.7 \%$ & $5.96 \mathrm{E}+06$ & $6.7 \%$ \\
\hline $\mathrm{Pu}-239 / 240$ & $7.45 \mathrm{E}+05$ & $7.8 \%$ & $7.07 \mathrm{E}+05$ & $8.5 \%$ & $6.71 \mathrm{E}+05$ & $7.8 \%$ & $6.30 \mathrm{E}+05$ & $6.8 \%$ \\
\hline Am-241 & $2.57 \mathrm{E}+06$ & $20 \%$ & $2.23 \mathrm{E}+06$ & $17 \%$ & $2.25 \mathrm{E}+06$ & $16 \%$ & $2.49 \mathrm{E}+06$ & $18 \%$ \\
\hline Am-243 & $2.90 \mathrm{E}+04$ & $22 \%$ & $2.34 \mathrm{E}+04$ & $20 \%$ & $2.27 \mathrm{E}+04$ & $19 \%$ & $2.76 \mathrm{E}+04$ & $21 \%$ \\
\hline Am-242m & $3.16 \mathrm{E}+03$ & $23 \%$ & $3.29 \mathrm{E}+03$ & $19 \%$ & $2.80 \mathrm{E}+03$ & $19 \%$ & $3.74 \mathrm{E}+03$ & $20 \%$ \\
\hline $\mathrm{Cm}-243$ & $<1.74 \mathrm{E}+04$ & NA & $<1.50 \mathrm{E}+04$ & NA & $<2.51 \mathrm{E}+04$ & NA & $<2.36 \mathrm{E}+04$ & NA \\
\hline $\mathrm{Cm}-245$ & $<1.46 \mathrm{E}+04$ & NA & $<1.26 \mathrm{E}+04$ & NA & $<5.83 \mathrm{E}+03$ & NA & $<8.47 \mathrm{E}+03$ & NA \\
\hline $\mathrm{Cm}-247$ & $<8.22 \mathrm{E}+03$ & NA & $<5.83 \mathrm{E}+03$ & NA & $<4.92 \mathrm{E}+04$ & NA & $<3.33 \mathrm{E}+03$ & NA \\
\hline $\mathrm{Cm}-242$ & $2.61 \mathrm{E}+03$ & $23 \%$ & $2.72 \mathrm{E}+03$ & $19 \%$ & $2.31 \mathrm{E}+03$ & $19 \%$ & $3.10 \mathrm{E}+03$ & $20 \%$ \\
\hline $\mathrm{Cm}-244$ & $1.62 \mathrm{E}+06$ & $25 \%$ & $1.34 \mathrm{E}+06$ & $22 \%$ & $1.32 \mathrm{E}+06$ & $21 \%$ & $1.44 \mathrm{E}+06$ & $23 \%$ \\
\hline
\end{tabular}




\section{Distribution:}

T. B. Brown

M. E. Cercy

D. A. Crowley

D. E. Dooley

A. P. Fellinger

S. D. Fink

C. C. Herman

D. T. Hobbs

E. N. Hoffman

J. E. Hyatt

K. M. Kostelnik

B. B. Looney

T. O. Oliver

F. M. Pennebaker

G. N. Smoland

B. J. Wiedenman

W. R. Wilmarth

Records Administration (EDWS)

P. R. Jackson, DOE-SR

J. A. Crenshaw

H. P. Boyd

J. M. Bricker

J. S. Contardi

T. L. Fellinger

E. J. Freed

J. M. Gillam

B. A. Hamm

E. W. Holtzscheiter

J. F. Iaukea

V. Jain

C. J. Martino

J. W. Ray

P. J. Ryan

M. A. Rios-Armstrong

H. B. Shah

D. C. Sherburne

C. B. Sudduth

S. T. Isom

J. D. Newell

C. L. Crawford

J. M. Pareizs

J. R. Zamecnik

W. H. Woodham

D. P. Lambert

V. M. Kmiec

F. C. Johnson

L. T. Reid 